University of South Florida

DIGITAL COMMONS

@ UNIVERSITY OF SOUTH FLORIDA
Digital Commons @ University of

South Florida

$7-1-2013$

\title{
Ridership Impacts of South Florida's EASY Smart Card
}

CUTR

Follow this and additional works at: https://digitalcommons.usf.edu/cutr_nctr

\section{Recommended Citation}

"Ridership Impacts of South Florida's EASY Smart Card," National Center for Transit Research (NCTR) Report No. CUTR-NCTR-RR-2012-12, Center for Urban Transportation Research, University of South Florida, 2013.

DOI: https://doi.org/10.5038/CUTR-NCTR-RR-2012-12

Available at: https://scholarcommons.usf.edu/cutr_nctr/99

This Technical Report is brought to you for free and open access by the National Center for Transit Research (NCTR) Archive (2000-2020) at Digital Commons @ University of South Florida. It has been accepted for inclusion in Research Reports by an authorized administrator of Digital Commons @ University of South Florida. For more information, please contact digitalcommons@usf.edu. 


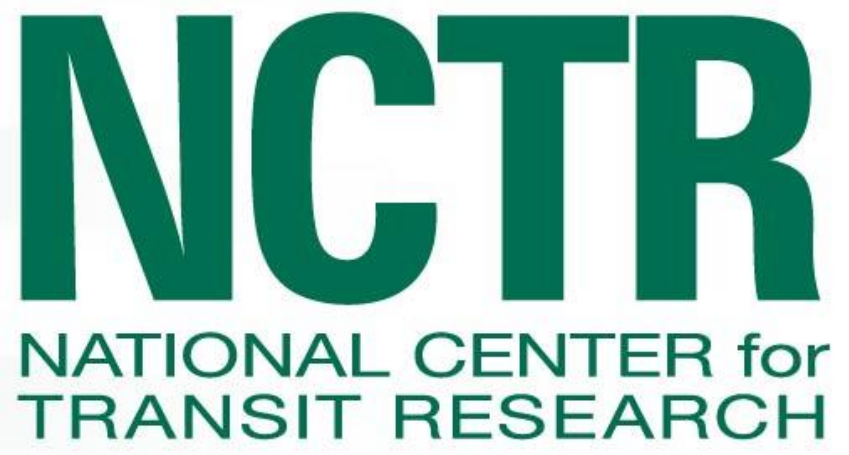

\section{Ridership Impacts of South Florida's EASY Smart Card}

\section{Final Report \\ Project No. BDK85 977-42}

July 2013

PREPARED FOR:

Florida Department of Transportation

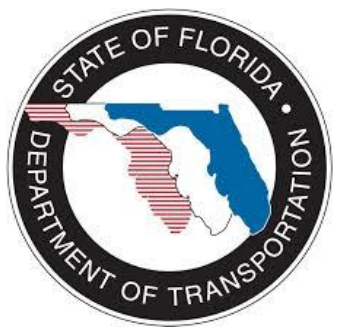





\section{Ridership Impacts of South Florida's EASY Smart Card}

Prepared for:

Florida Department of Transportation

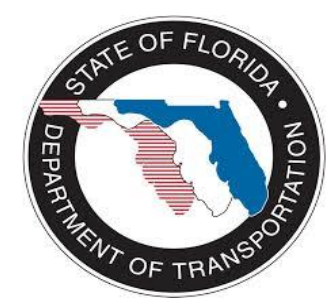

Project Manager:

Gabrielle Mathews

FDOT Transit Office

Prepared by:

Ann Joslin and William Morris

National Center for Transit Research

Center for Urban Transportation Research (CUTR)

University of South Florida

4202 East Fowler Avenue, CUT 100

Tampa, FL 33620

\section{Final Report}

July 2013

Project No. BDK85 977-42 


\section{Disclaimer}

The contents of this report reflect the views of the authors, who are responsible for the facts and the accuracy of the information presented herein. This document is disseminated under the sponsorship of the Department of Transportation University Transportation Centers Program and the Florida Department of Transportation, in the interest of information exchange. The U.S. Department of Transportation and the Florida Department of Transportation asssume no liability for the contents or use thereof.

The opinions, findings, and conclusions expressed in this publication are those of the authors and not necessarily those of the State of Florida Department of Transportation (FDOT). 


\section{Metric Conversion}

\begin{tabular}{|c|c|c|c|c|}
\hline SYMBOL & $\begin{array}{l}\text { WHEN YOU } \\
\text { KNOW }\end{array}$ & MULTIPLY BY & TO FIND & SYMBOL \\
\hline \multicolumn{5}{|c|}{ LENGTH } \\
\hline in & inches & 25.4 & millimeters & $\mathrm{mm}$ \\
\hline ft & feet & 0.305 & meters & $\mathrm{m}$ \\
\hline yd & yards & 0.914 & meters & $\mathrm{m}$ \\
\hline $\mathbf{m i}$ & miles & 1.61 & kilometers & $\mathrm{km}$ \\
\hline \multicolumn{5}{|c|}{ VOLUME } \\
\hline fl oz & fluid ounces & 29.57 & milliliters & $\mathrm{mL}$ \\
\hline gal & gallons & 3.785 & liters & L \\
\hline $\mathrm{ft}^{3}$ & cubic feet & 0.028 & cubic meters & $\mathrm{m}^{3}$ \\
\hline$y d^{3}$ & cubic yards & 0.765 & cubic meters & $\mathrm{m}^{3}$ \\
\hline \multicolumn{5}{|c|}{ NOTE: volumes greater than $1000 \mathrm{~L}$ shall be shown in $\mathrm{m}^{3}$} \\
\hline \multicolumn{5}{|c|}{ MASS } \\
\hline $\mathbf{o z}$ & ounces & 28.35 & grams & $g$ \\
\hline Ib & pounds & 0.454 & kilograms & $\mathrm{kg}$ \\
\hline $\mathbf{T}$ & $\begin{array}{l}\text { short tons (2000 } \\
\text { lb) }\end{array}$ & 0.907 & $\begin{array}{c}\text { megagrams } \\
\text { (or "metric ton") }\end{array}$ & $\mathrm{Mg}(\mathrm{or}$ "t") \\
\hline \multicolumn{5}{|c|}{ TEMPERATURE (exact degrees) } \\
\hline${ }^{\circ} \mathbf{F}$ & Fahrenheit & $\begin{array}{c}5(F-32) / 9 \\
\text { or }(F-32) / 1.8\end{array}$ & Celsius & ${ }^{\circ} \mathrm{C}$ \\
\hline
\end{tabular}




\section{Technical Report Documentation}

\begin{tabular}{|l|l|l|}
\hline $\begin{array}{l}\text { 1. Report No. } \\
\text { BDK85 977-42 }\end{array}$ & 2. Government Accession No. & $\begin{array}{l}\text { 3. Recipient's } \\
\text { Catalog No. }\end{array}$ \\
\hline $\begin{array}{l}\text { 4. Title and Subtitle } \\
\text { Ridership Impacts of South Florida's EASY Smart Card }\end{array}$ & $\begin{array}{l}\text { 5. Report Date } \\
\text { July } 2013\end{array}$ \\
\hline $\begin{array}{l}\text { 6. Performing Organization Code } \\
\end{array}$
\end{tabular}

\begin{tabular}{|c|c|}
\hline $\begin{array}{l}\text { 7. Author(s) } \\
\text { Ann Joslin and William P. Morris }\end{array}$ & $\begin{array}{l}\text { 8. Performing Organization Report } \\
\text { No. } \\
\text { NCTR 77946/BDK85 977-42 } \\
\text { U.S.DOT DTRS98-G-0032 }\end{array}$ \\
\hline $\begin{array}{l}\text { 9. Performing Organization Name and Address } \\
\text { National Center for Transit Research } \\
\text { Center for Urban Transportation Research (CUTR) } \\
\text { University of South Florida } \\
4202 \text { East Fowler Avenue, CUT100 } \\
\text { Tampa, FL 33620-5375 }\end{array}$ & 10. Work Unit No. (TRAIS) \\
\hline $\begin{array}{l}\text { 11. Contract or Grant No. } \\
\text { BDK85 } 977-42\end{array}$ & \\
\hline
\end{tabular}

\begin{tabular}{l|l}
$\begin{array}{l}\text { 12. Sponsoring Agency Name and Address } \\
\text { Florida Department of Transportation }\end{array}$ & $\begin{array}{l}\text { 13. Type of Report and Period } \\
\text { Covered }\end{array}$
\end{tabular}

Research Center, 605 Suwannee Street, MS30

Tallahassee, FL 32399

Final $1 / 25 / 2012-8 / 31 / 2013$

Research and Innovative Technology Administration

U.S. Department of Transportation

Mail Code RDT-30, 1200 New Jersey Ave, SE, Room E33

Washington, DC 20590-0001

\section{Sponsoring Agency Code}

\section{Supplementary Notes}

\section{Abstract}

Smart card-based Automated Fare Collection Systems (AFCS) are being increasingly deployed in transit systems across the US. Miami-Dade Transit (MDT) has recently deployed such a system branded as the EASY Card. The South Florida Regional Transportation Authority (SFRTA) also deployed the same system for Tri-Rail. The technology provides a stored value electronic purse or the choice of various period passes, and in that respect is similar to smart card systems in other US cities. The EASY Card system will be used as a case study to document some of the issues related to the ridership and customer behavior aspects related to fare policy when smart card systems are introduced. Given the benefits of such AFCS in terms of reduced fare evasion, cash handling fraud, transfer abuse and increased customer convenience, it is likely that other transit systems in Florida will deploy such systems in future years.

\section{Key Words}

Smart Card, Fare Collection

19. Security

Classification (of this

report)

Unclassified
18. Distribution Statement

21. No. of Pages 106 22. Price 


\section{Executive Summary}

The National Center for Transit Research (NCTR), with funding provided by the Florida Department of Transportation (FDOT) and the United States Department of Transportation (USDOT), commissioned this study entitled, "Ridership Impacts of South Florida's EASY Smart Card" to document some of the issues related to fare policy when smart cards are introduced. The EASY Card system has been used as a case study to evaluate issues related to organizational decision-making regarding implementation, fare policy, consumption, revenue, ridership and customer behavior aspects related to smart card implementation.

Over the last decade or so, there have been a number of research reports and evaluations of Automated Fare Collection Systems (AFCS), and in particular, smart cards. Much of the relevant literature and trade journal articles have focused on AFCS technology, benefits anticipated by implementing agencies, and the institutional arrangements and challenges related to regional fare collection system deployments.

In 2009, Miami-Dade Transit (MDT) was the first Florida transit system to deploy an AFCS or "smart card" system branded EASY Card. EASY Card offers the choice of various period passes and a stored value electronic purse. MDT designed the EASY Card system to allow for future integration with other transit providers in the region such as the South Florida Regional Transit Authority's TriRail, Palm Tran, and Broward County Transit. MDT completed enhancements to the technology infrastructure that was necessary to integrate Tri-Rail with the EASY Card system which was introduced at Tri-Rail in February 2011. Transit customers now have the ability to use a single fare instrument (EASY Card) to pay fares on both systems.

To prepare for the EASY Card system deployment, MDT developed a detailed customer service business plan to ensure internal staff were knowledgeable about the new system and able to respond to any customer comments or concerns. MDT also conducted an extensive customer outreach and educational campaign using media and grass roots efforts to inform customers of the benefits of the new system and prepare them for the techological and fare policy changes as a result of the new EASY Card system.

Successful techniques used to enhance adoption and satisfaction included the distribution of free introductory EASY Cards, and for a short period of time following roll-out, some flexibility in terms of fare payment or fare forgiveness for customers who encountered difficulties understanding the new system. Still, there was some initial resistance to adopting the new fare technology, the most problematic being the new requirement that customers tap the EASY Card or EASY Ticket on the farebox or faregate to ensure the appropriate fares were charged.

The most notable changes associated with the introduction of EASY Card were related to the elimination of paper and magnetic tranfers which were replaced by transfers encoded on the EASY Card. If customers transfer using an EASY Card or EASY Ticket transfers are free. However, customers paying cash must pay the full $\$ 2.00$ full fare (or reduced fare) each time they board a bus. Additionally, all other forms of payment were eliminated on Metrorail. EASY Cards and EASY Tickets are now the only form of fare payment accepted on Metrorail. 
There have been significant fluctutations in in MDT's overall ridership over the last several years. In FY 2008 Metrobus ridership was was 84.8 million and by 2012 ridership was 75.6 million. Between FY 2008 and FY 2012 Metrorail ridership increased from 18.5 million to 18.7 million. These fluctuations were likely a result of economic conditions and other external factors such as demographic changes, fuel prices and service changes, making it difficult to draw conclusions regarding ridership impacts directly attributable to implementation of the AFCS.

Although this study could not directly correlate ridership with the availaibility of EASY Cards and EASY Tickets, the new fare media is used by a majority of MDT customers. In 2011, total EASY Card/EASY Ticket ridership was 69.9 million, or 74.9 percent of the total ridership of 93.3 million. In 2012, total EASY Card/EASY Ticket ridership increased to 70.8 million and was 73.3 percent of the total ridership of 96.5 million for Metrobus and Metrorail. While there were no significant changes, the fact is that within three years of implementation, three of every four trips taken are paid with EASY Cards or EASY Tickets.

In terms of customer satisfaction, there was some initial resistance and confusion adapting to the new fare technology. Most notable was the new requirement that customers needed to tap their EASY Cards or EASY Tickets on the fare box or faregate to ensure the appropriate fares were charge.

MDT was successful in establishing a large network of outlets for EASY Card sales. The most popular, ticket vending machines, accounted for 62.6 percent of all sales between FY 2010 and FY 2012. Eighty-four retail outlets generated approximately $\$ 31.6$ million in sales, or 23.3 percent of sales for the three year period, and ticket office machines accounted for $\$ 13.2$ million in sales for the same period. Although still a relatively small portion of overall MDT fare sales, the popularity of internet sales grew significantly between FY 2010 and FY 2012 in all major fare categories.

In addition, MDT's Corporate Discount Program (CDP) allows participants to save though group discounts and pre-tax payroll deductions with monthly transit passes loaded on EASY Cards. Although the number of participating corporations increased from 179 in 2010 to 185 in 2012, total sales decreased sightly during the same period. The University/College Discount Program (CUPD) allows full time students to purchase half-price $(\$ 50)$ monthly passes loaded on EASY Tickets. This program has proven successful with 42 participating institutions in 2012 (up from 30 in 2010) and a 9.6 percent increase in sales for the same period.

This report includes a detailed analysis of customer response to the EASY Card system in terms of ridership by mode, and fare media choice and purchase options. For example, the EASY Card Stored Value Full Fare was the most popular Metrorail fare category and was also the most popular on 7 of 10 of the highest ridership Metrobus routes. Metrobus cash ridership grew by approximately 151,000 (from 22.9 million to just over 23.0 million between 2011 and 2012), while the sales of EASY Card and EASY Ticket combined grew by approximately 2.2 million during the same period. TVM data also shows that cash payment for stored value products (77 percent) still far exceeds credit or debit card transcations. 
The following observations and recommendations offered by agency staff are not necessarily a direct or immediate impact on ridership, customer acceptance, or adoption, but may be useful to others considering AFCS deployment including current initiatives underway in Southeast and Central Florida, and in the Tampa Bay region:

- Reports of fraudulent activity associated with EASY Card have been minimal, but additional controls to enable validation of credit card purchases in the event of a communications failure should be considered.

- Anticipate significant benefits in terms of enhanced system functionality, control, ridership and revenue reporting, and data reliability.

- Don't rush - create a reasonable implementation schedule.

- Carefully evaluate fare policy and structure and incorporate desired changes before introducing the AFCS.

- Create a thorough and well-designed card distribution plan, with special consideration and attention to the needs of corporate customers.

- Engage agency representatives from all functional areas in planning and deployment. Develop a thorough documentation of business practices for each department to make transition activities smoother and operating in post-implementation more efficient.

- Anticipate the need for additional financial and accounting staff and create a business processing system closely aligned with the Information Technology function.

- Pre-define reporting requirements and data needs by functional area. 
This page intentionally left blank 


\section{Table of Contents}

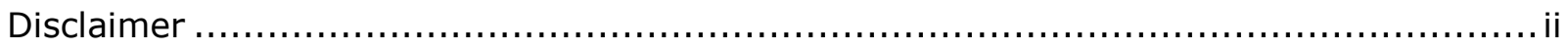

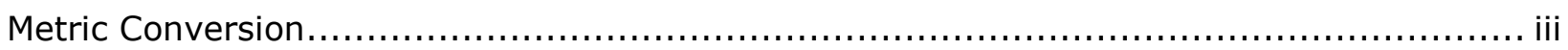

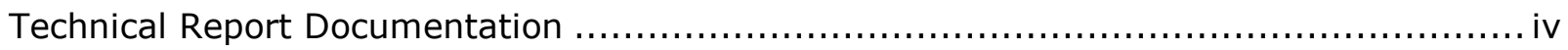

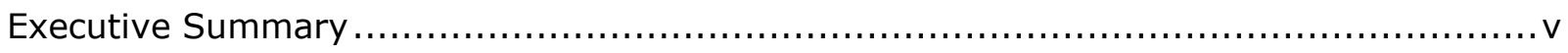

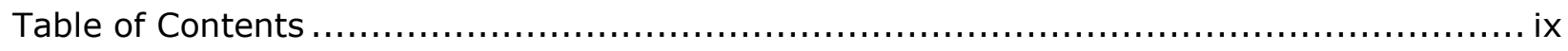

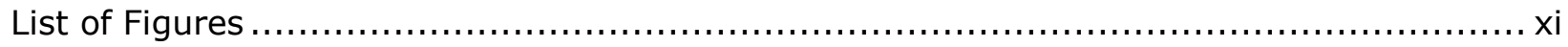

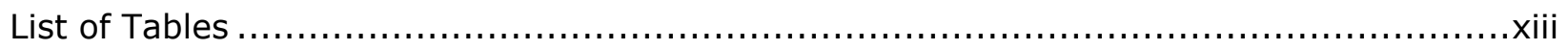

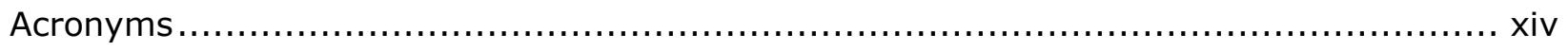

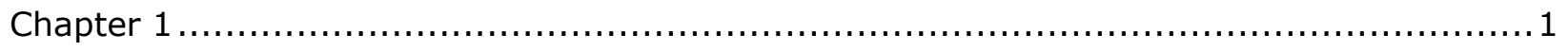

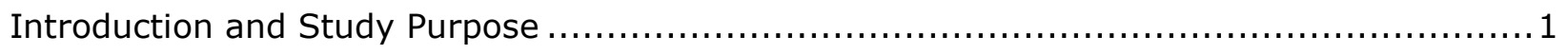

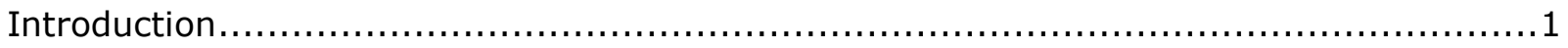

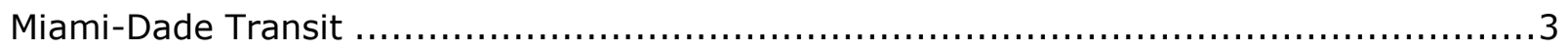

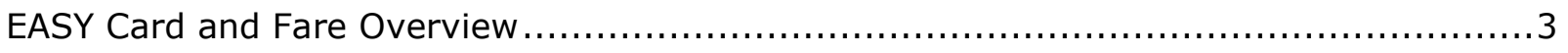

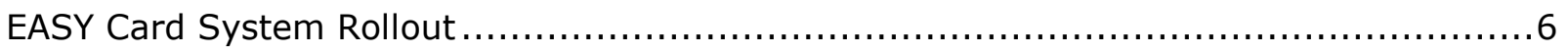

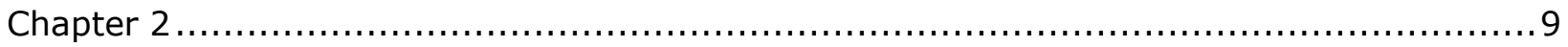

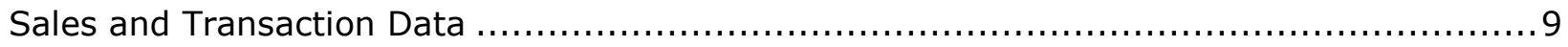

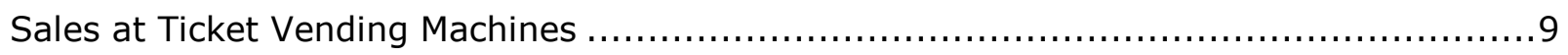

Annual TVM Sales Broken Down by Transactions for EASY Cards and EASY Tickets ..........9

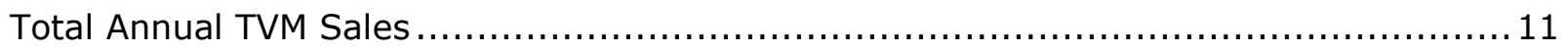

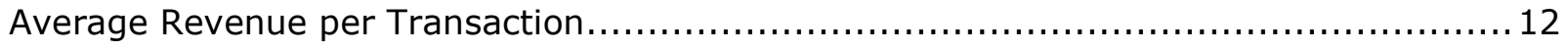

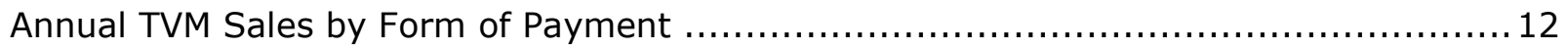

Three Year Cumulative Total of Sales at Metrorail Stations and Golden Glades ............ 13

Annual Sales at Metrorail Stations and Golden Glades .................................. 17

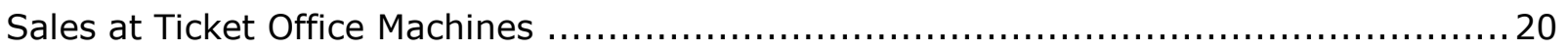

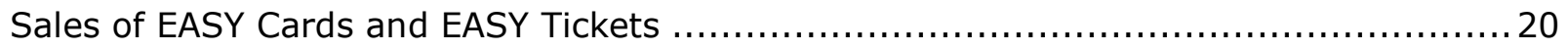

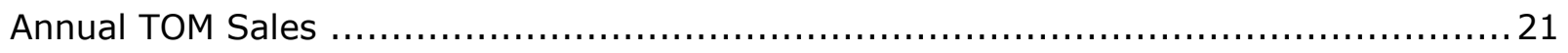

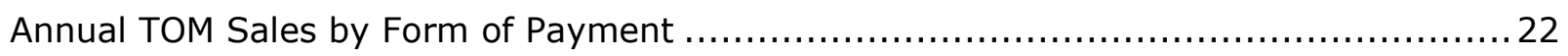

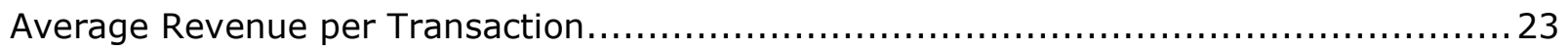

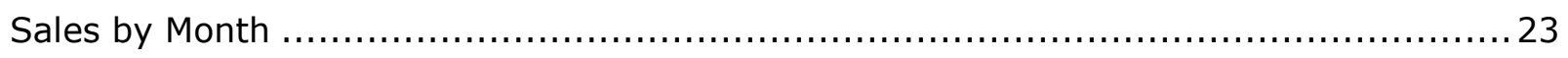

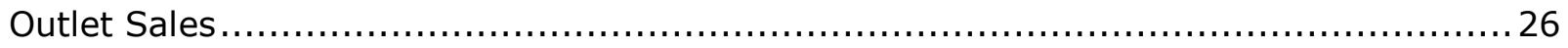

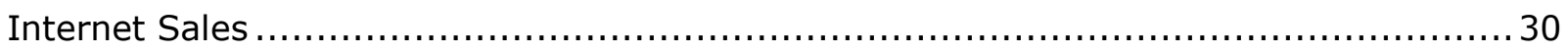

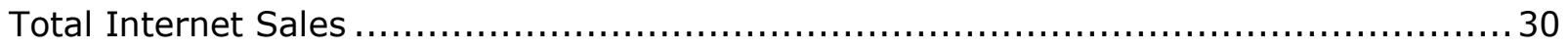

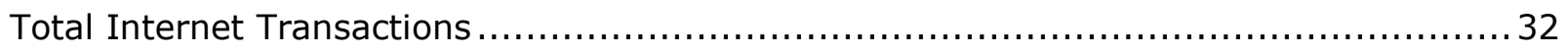




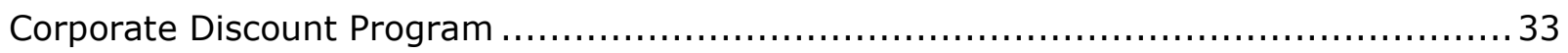

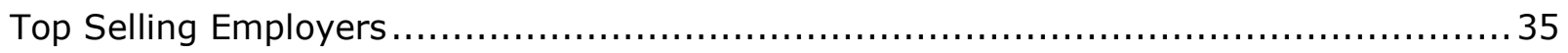

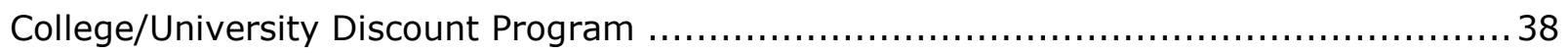

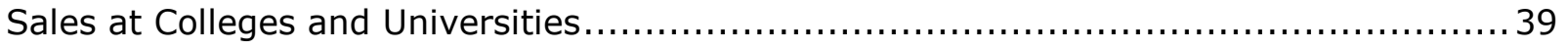

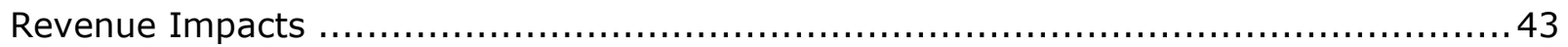

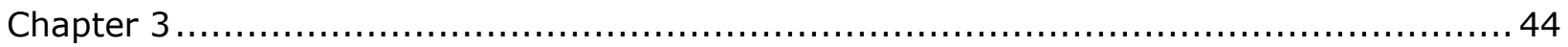

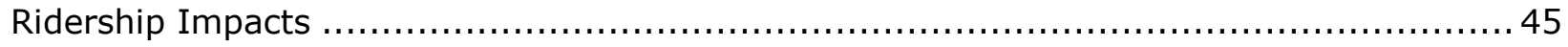

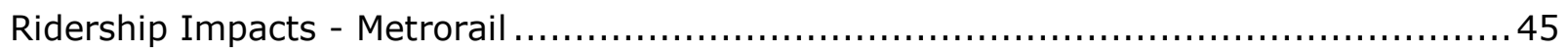

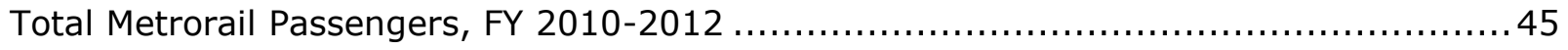

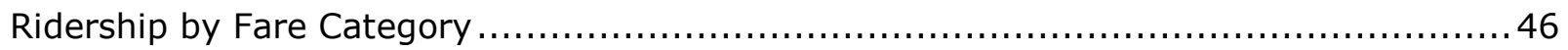

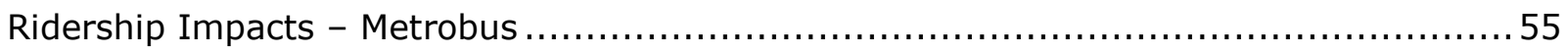

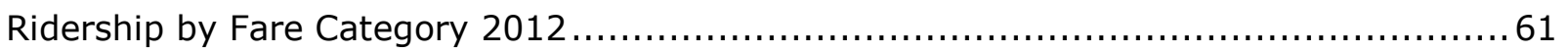

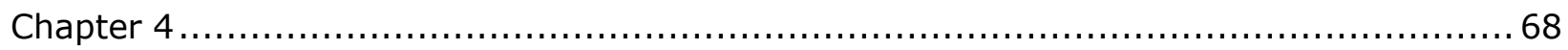

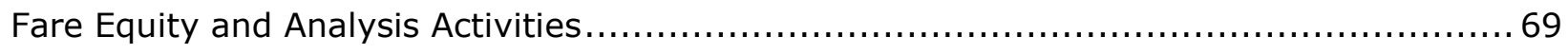

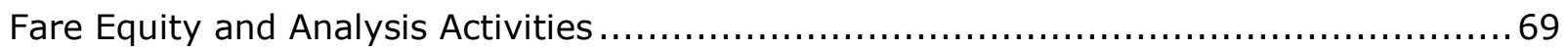

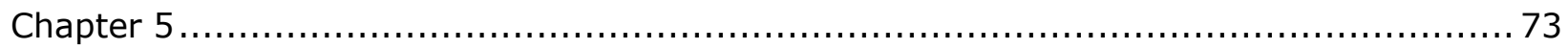

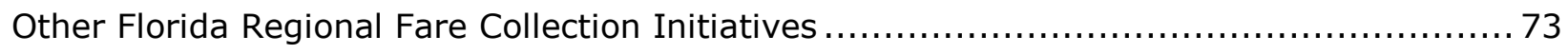

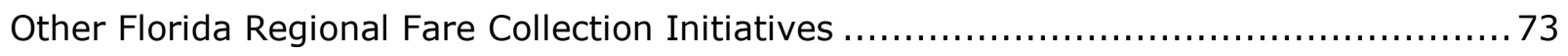

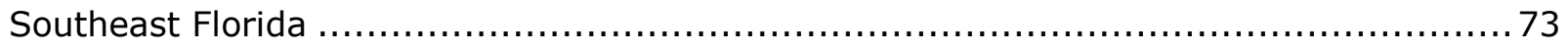

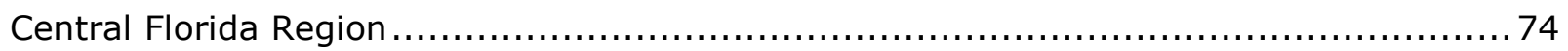

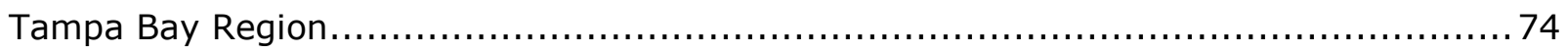

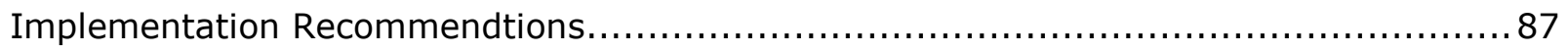

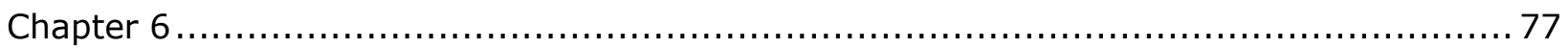

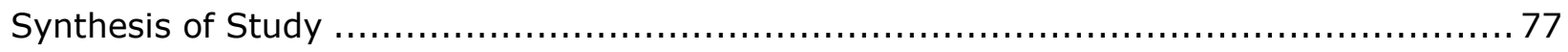

Fare Policy Changes and Incentives Associated with the EASY Card System ............. 77

Ridership Impacts, Trip Characteristics and Trip Patterns................................. 78

Growth Rate of EASY Card/EASY Ticket in Post-Implementation . .......................... 78

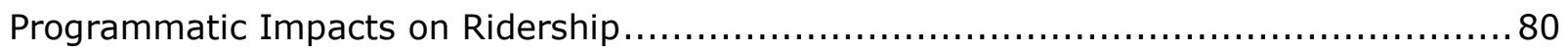

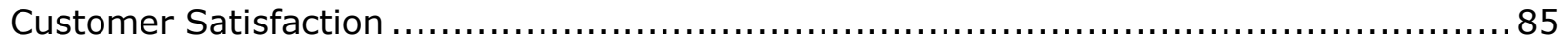

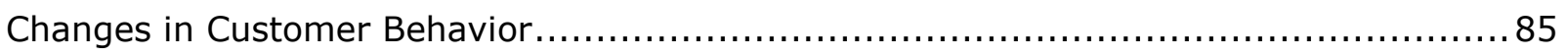

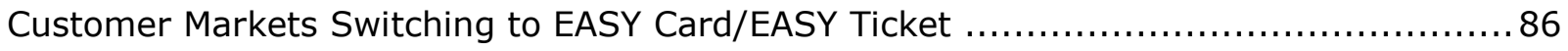

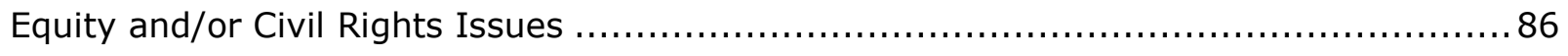

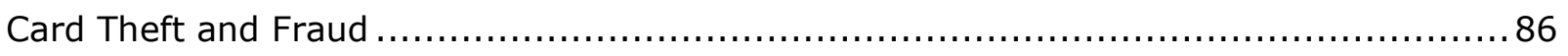

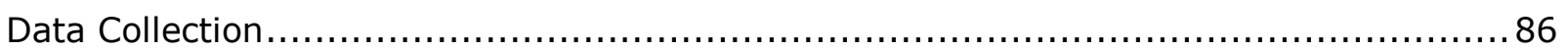

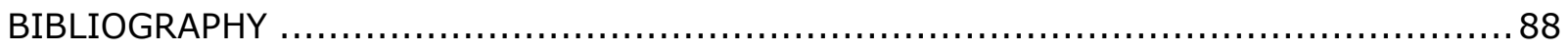

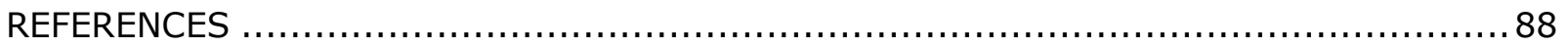




\section{List of Figures}

Figure 2-1: Ticket Vending Machines 9

Figure 2-2. Annual Ticket Vending Machines (TVM) Sales Broken Down by Transactions for

EASY Cards vs. EASY Tickets (FY 2010 - FY 2012) ........................... 10

Figure 2-3. Annual Ticket Vending Machines (TVM) Sales (FY 2010 - FY 2012) ...............11

Figure 2-4. Annual TVM Sales by Form of Payment (FY 2010- FY 2012) ...................... 12

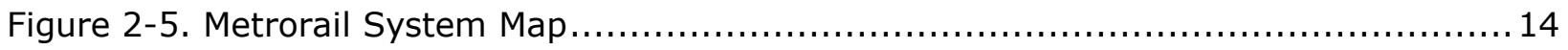

Figure 2-6. TVM Sales, Metrorail, Top 12 Highest Selling Stations: $2010-2012$.............15

Figure 2-7. TVM Sales, Metrorail, Sales of Remaining Stations: $2010-2012 \ldots \ldots \ldots \ldots \ldots \ldots \ldots$

Figure 2-8. TVM Sales, Metrorail, Top 12 Highest-Selling Stations: FY $2010 \ldots \ldots \ldots \ldots \ldots \ldots 17$

Figure 2-9. TVM Sales, Metrorail, Sales of Remaining Stations: FY $2010 \ldots \ldots \ldots \ldots \ldots \ldots \ldots 18$

Figure 2-10. TVM Sales, Metrorail, Top 12 Highest Selling Stations: FY $2011 \ldots \ldots \ldots \ldots \ldots 18$

Figure 2-11. TVM Sales, Metrorail, Sales of Remaining Stations: FY $2011 \ldots \ldots \ldots \ldots \ldots \ldots \ldots$

Figure 2-12. TVM Sales, Metrorail, Top 12 Highest Selling Stations: FY 2012 ................ 19

Figure 2-13. TVM Sales, Metrorail, Sales of Remaining Stations: FY $2012 \ldots \ldots \ldots \ldots \ldots \ldots \ldots . \ldots 20$

Figure 2-14. Annual Ticket Office Machines (TOM) Sales Broken Down by EASY Card and

EASY Ticket Transactions (FY 2010 - FY 2012) ............................. 21

Figure 2-15. Annual TOM Sales (FY 2010 - FY 2012) ....................................... 22

Figure 2-16. Annual TOM Sales by Form of Payment (FY 2010- FY 2012) ................... 23

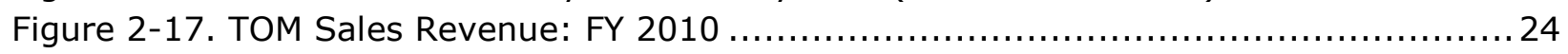

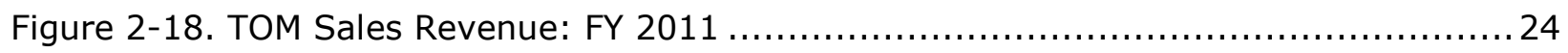

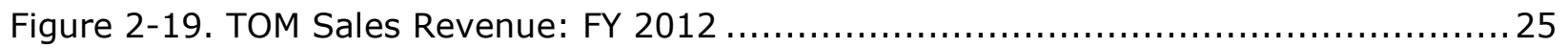

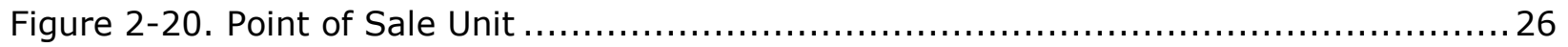

Figure 2-21. Miami-Dade Transit Outlet Revenues: October 2010 - September $2011 \ldots \ldots . .27$

Figure 2-22. Miami-Dade Transit Outlet Revenues: October 2009 - September 2010 ....... 27

Figure 2-23. Miami-Dade Transit Outlet Revenues: October 2011- July $2012 \ldots \ldots \ldots \ldots \ldots . \ldots 28$

Figure 2-24. Miami-Dade Transit Outlet Revenues: Total Annual Revenue, FY 2010-2012.. 28

Figure 2-25. Miami-Dade Transit Outlet Revenues: Total Annual Revenue, FY 2010-2012

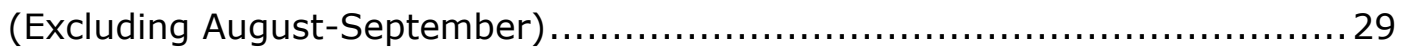

Figure 2-26. Miami-Dade Transit EASY Card Home Page ..................................... 30

Figure 2-27. Web Sales: All Types, Total Revenue (FY 2010-2012) ........................ 31

Figure 2-28. Web Sales: All Types, Total Number of Products Sold (FY 2010-2012) ......... 33

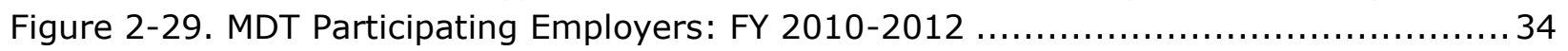

Figure 2-30. Total Sales for all Participating Employers: FY 2010-2012 .................... 35

Figure 2-31. University of Miami School of Medicine: CDP Sales - FY 2010-2012 .......... 36

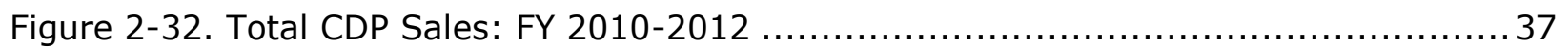

Figure 2-33. Number of Participating Institutions, By Year: FY 2010-2012 .................. 39

Figure 2-34. Total College/University Sales: FY 2010-2012 ............................... 40

Figure 2-35. Miami-Dade College: College Pass Sales, FY 2010-2012 ...................... 40

Figure 2-36. Total College Pass Sales: Top Sellers, FY 2010-2012 .......................41

Figure 2-37. Total College Pass Sales: Remaining Sales, FY $2010-2012 \ldots \ldots \ldots \ldots \ldots \ldots \ldots . \ldots 42$

Figure 2-38. Total Cumulative Sales - All Outlets and Programs, FY 2010- 2012...........43 


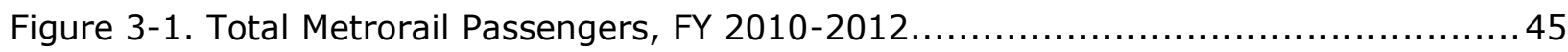

Figure 3-2. Ridership by Most Utilized Fare Categories: EASY Card and EASY Ticket

(October 2009 - September 2010) ............................................ 47

Figure 3-3. Ridership by Next Most Utilized Fare Categories - EASY Card and EASY Ticket

(October 2009 - September 2010) ...................................... 48

Figure 3-4. Ridership by Most Utilized Fare Categories: EASY Card and EASY Ticket

(October 2010 - September 2011) .......................................... 50

Figure 3-5. Ridership by Next Most Utilized Fare Categories EASY Card and EASY Ticket

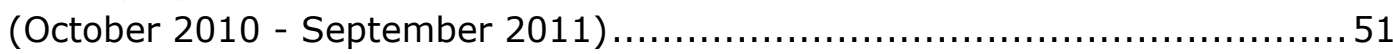

Figure 3-6. Ridership by Most Utilized Fare Categories: EASY Card and EASY Ticket

(October 2011 - September 2012) ............................................ 53

Figure 3-7 . Ridership by Next Most Utilized Fare Categories - EASY Card and EASY

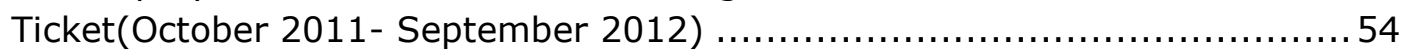

Figure 3-8. Ridership by Method of Payment, FY 2011-2012 ............................56

Figure 3-9. Total Annual Ridership (in millions) by Method of Payment and as a

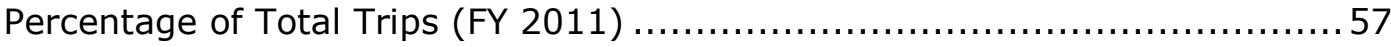

Figure 3-10. Total Annual Ridership by Method of Payment and as a Percentage of Total

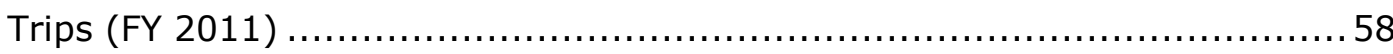

Figure 3-11. Total Annual Ridership by Method of Payment and as a Percentage of Total

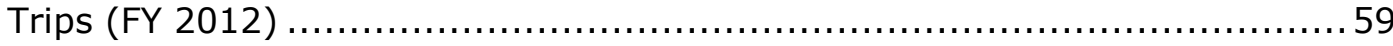

Figure 3-12. Total Annual Ridership by Method of Payment and as a Percentage of Total

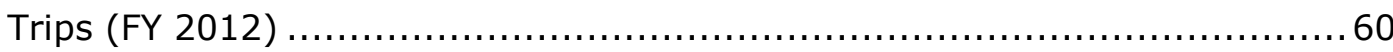

Figure 3-13. Percentage Change in Ridership by Method of Payment, FY 2011 - FY 2012..661

Figure 3-14. Route 3 Highest Ridership Levels by Fare Category, FY 2012 ................6 62

Figure 3-15. Route 7 Highest Ridership Levels by Fare Category, FY $2012 \ldots \ldots \ldots \ldots \ldots \ldots \ldots 63$

Figure 3-16. Route 8 Highest Ridership Levels by Fare Category, FY 2012 .................6 64

Figure 3-17. Route 9 Highest Ridership Levels by Fare Category, FY $2012 \ldots \ldots \ldots \ldots \ldots \ldots . \ldots 4$

Figure 3-18. Route 11 Highest Ridership Levels by Fare Category, FY 2012 ................65

Figure 3-19. Route 22 Highest Ridership Levels by Fare Category, FY 2012 .................65

Figure 3-20. Route 27 Highest Ridership Levels by Fare Category, FY $2012 \ldots \ldots \ldots \ldots \ldots \ldots 66$

Figure 3-21. Route 37 Highest Ridership Levels by Fare Category, FY 2012 .................66

Figure 3-22. Route 38 Highest Ridership Levels by Fare Category, FY 2012 ................6 67

Figure 3-23. Route 77 Highest Ridership Levels by Fare Category, FY $2012 \ldots \ldots \ldots \ldots \ldots \ldots . . .67$

Figure 6-1. Metrorail Ridership by Fare Type, FY 2010-2012 …........................ 79

Figure 6-2. Metrobus Ridership by Method of Payment, FY 2011-2012 ...................... 79

Figure 6-3. Combined Easy Card/Easy Ticket Ridership Compared to Total Metrobus +

Metrorail Ridership, FY 2011-2012 ....................................... 80

Figure 6-4. Metrorail - 7 Day Corporate Pass/PPB Monthly Pass Annual Ridership

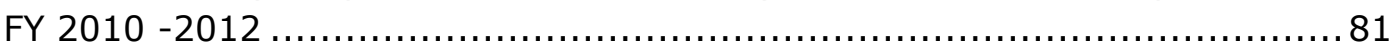

Figure 6-5. Metrobus Ridership - Corporate Discount Program, Annual Ridership,

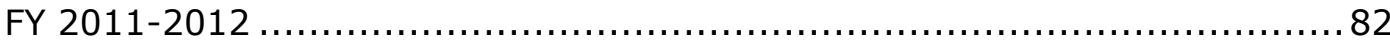

Figure 6-6. Metrorail - Stored Value Elderly/Annual SSB Annual Ridership,

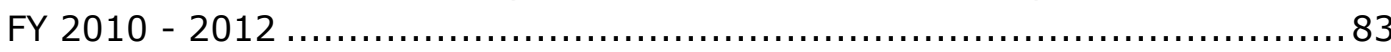

Figure 6-7. Metrorail - Annual Patriot Pass Ridership, FY 2010- 2012 ..................... 84

Figure 6-8. Metrobus Ridership - Annual Patriot Pass, Annual Ridership........................ 84 


\section{List of Tables}

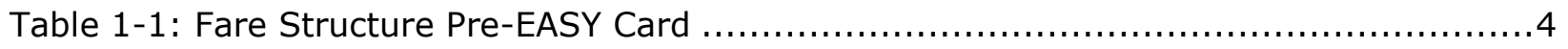

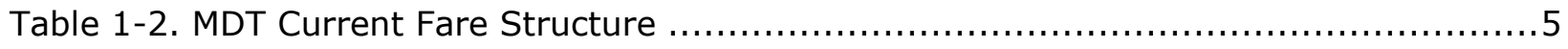

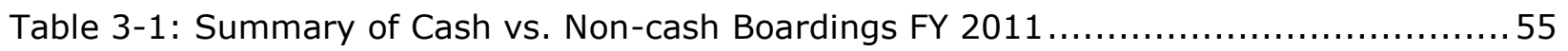

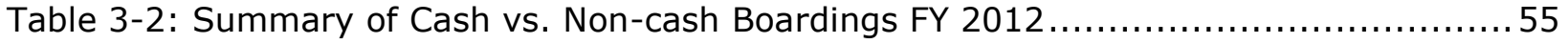




\section{Acronyms}

$\begin{array}{ll}\text { AFCS } & \text { Automated Fare Collection System } \\ \text { APC } & \text { Automated Passenger Counters } \\ \text { API } & \text { Application Programming Interface } \\ \text { APM } & \text { Automated People Mover } \\ \text { AB } & \text { Arterial Busway } \\ \text { BCT } & \text { Broward County Transit } \\ \text { BRT } & \text { Bus Rapid Transit } \\ \text { CCS } & \text { Central Computer System } \\ \text { CDP } & \text { Corporate Discount Program } \\ \text { CUDP } & \text { College/University Discount Program } \\ \text { CPOS } & \text { Compact Point of Sale } \\ \text { CSBP } & \text { Customer Service Business Plan } \\ \text { EDP } & \text { Employer Discount Program } \\ \text { ESRI } & \text { Economic and Social Research Institute } \\ \text { FDOT } & \text { Florida Department of Transportation } \\ \text { FIU } & \text { Florida International University } \\ \text { FTA } & \text { Federal Transit Administration } \\ \text { ID } & \text { Identification } \\ \text { LU } & \text { Stored Value Limited Use } \\ \text { MDC } & \text { Miami-Dade College } \\ \text { MDT } & \text { Miami Dade Transit } \\ \text { MDC } & \text { Miami-Dade College } \\ \text { MTC } & \text { Metroplitin Transprortation Commission } \\ \text { NCTR } & \text { National Center for Transit Research } \\ \text { POSU } & \text { Point of Sale Unit } \\ \text { PPB } & \text { Pre-paid Benefit } \\ \text { PFT } & \text { South Florida Regional Transit Authority }\end{array}$


STS Special Transportation Services

TCRP Transit Cooperative Research Program

TOM Ticket Office Machines

TRB Transportation Research Board

TVM Ticket Vending Machines

UM University of Miami

USDOT United States Department of Transportation 
This page intentionally left blank 


\section{Chapter 1}

\section{Introduction and Study Purpose}

\section{Introduction}

In 2009, Miami-Dade Transit (MDT) was the first Florida transit system to deploy an Automated Fare Collection System (AFCS) or "smart card" system branded EASY Card. EASY Card offers the choice of various period passes and a stored value electronic purse. MDT designed the EASY Card system to allow for future integration with other transit providers in the region such as the South Florida Regional Transit Authority's TriRail, Palm Tran, and Broward County Transit. MDT completed the technology infrastructure that was necessary to integrate Tri-Rail with the EASY Card system, which was introduced at Tri-Rail in February 2011. Transit customers now have the ability to use a single fare instrument (EASY Card) to pay fares on both systems. In addition to the convenience of a universal fare product, customers are also able to register the EASY Card and receive balance protection in the event the card is lost or stolen. A free autoload feature is also available online or by calling the EASY Card Customer Service Center.

From the perspective of transit agencies, an AFCS has the potential to reduce fare evasion, cash handling fraud, and transfer abuse. Additional benefits identified by Miami-Dade Transit during the planning and development phase of EASY Card include:

- Replacing erratic magnetic stripe cards with more reliable technology will improve operating efficiencies and enhance the customer's travel experience.

- Patrons will be able to use alternate payment methods such as credit/bank cards.

- The validating fareboxes will recognize counterfeit currency.

- Automatic passenger counters (APCs) will provide accurate passenger counts not previously available.

- Incentives for EASY Card use can be implemented through participating vendors (e.g., \$ off coupons by presenting EASY Card).

- Faster bus boardings will decrease dwell time and improve headway performance.

- The AFCS system will provide more accurate reports to facilitate strategic planning.

- Electronic fareboxes will reduce bus operator involvement in the boarding process that allows them to concentrate on driving. ${ }^{1}$

Recent literature searches revealed a considerable number of reports and trade journal articles expounding the benefits of transit smart card systems or detailing challenges or controversies that have occurred in individual deployments. However, no significant efforts to document customer behavior and acceptance related to transit smart card deployment were identified.

In mid-January 2011, MDT successfully completed the technology infrastructure enhancements required to integrate Tri-Rail to the MDT AFCS. The zone-based integration for all 18 Tri-Rail stations (Approximately 72 miles and traversing Palm Beach, Broward and 
Miami Dade County) was completed in February 2011, to include 59 full service TVMs, 17 cashless TVMs, 85 rail station validators, six TOMs and five photo ID machines.

The AFCS made a new regional fare product possible in October 2011. The Regional Monthly Pass loaded on EASY Card costs $\$ 140$ and permits unlimited monthly rides on both Tri-Rail and MDT's Metrobus and Metrorail, allowing seamless tranfers between both systems and is the first step in a fully integrated transit system in South Florida.

The National Center for Transit Research (NCTR), with funding provided by the Florida Department of Transportation (FDOT) and the United States Department of Transportation (USDOT), commissioned the study, "Ridership Impacts of South Florida's EASY Smart Card" to document some of the issues related to fare policy when smart cards are introduced. The EASY Card system will be used as a case study to evaluate issues related to organizational decision-making, fare policy, consumption, revenue, ridership and customer behavior. Objectives of this study included:

- Identification of fare policy/structure choices that were made in conjunction with the deployment of smart cards and the agencies' rationale for policy changes.

- Identification of card distribution policies at sales outlets and via the internet.

- Examination of the degree to which employers or institutions such as universities are promoting the program for employees and students and the degree of success of such promotions.

- Acquisition, analysis and assimilation of data available from the agencies to examine fare media types and values, sales and revenue (via various sales outlets), ridership by mode and routes, and transfers (intra-and inter-system value).

- Acquire, analyze and assimilate data on fare policy and pricing. Determine whether there are strategies that promote or incentivise switching from traditional fare media to smart cards based on pricing and/or availability.

- Establish measures for customer convenience in comparison to stated predeployment benefits and actual passenger behavior or customer satisfaction based on survey data, if available.

- Promote awareness of issues experienced in South Florida for transit agencies considering an AFCS deployment.

- Assess and collect information regarding how agencies address criminal activity including but not limited to: card theft and creation and distribution of fraudulent cards.

- Assess availability of collateral data displaying levels of customer satisfaction, ridership impacts, age, origin/destination and frequency of use and summarize findings.

Given the benefits of an AFCS in terms of reduced fare evasion, cash handling, fraud, transfer abuse, and increased customer convenience, other Florida transit systems are following in the footsteps of South Florida and are in various stages of planning or implementation of similar systems. The EASY Card case study will provide a summary of 
lessons learned and pitfalls to avoid so that other agencies may benefit from a South Florida experience when implementating an AFCS.

\section{Miami-Dade Transit}

MDT operates the 14th largest transit system in the United States and is the largest transit system in the State of Florida. MDT is one of the largest departments in Miami-Dade County government. MDT operates four modes of transit service: bus (Metrobus), heavy rail (Metrorail), automated people-mover (Metromover), and demand-response service (Special Transportation Services or STS). Metrobus service includes local, feeder, circulator, limitedstop, express, and Bus Rapid Transit (BRT) Busway. Together these modes comprise an integrated multimodal transit system for Miami-Dade County with more than 327,500 daily (weekday) boardings on the MDT system while STS's average daily boardings are approximately $5,100 .^{2}$

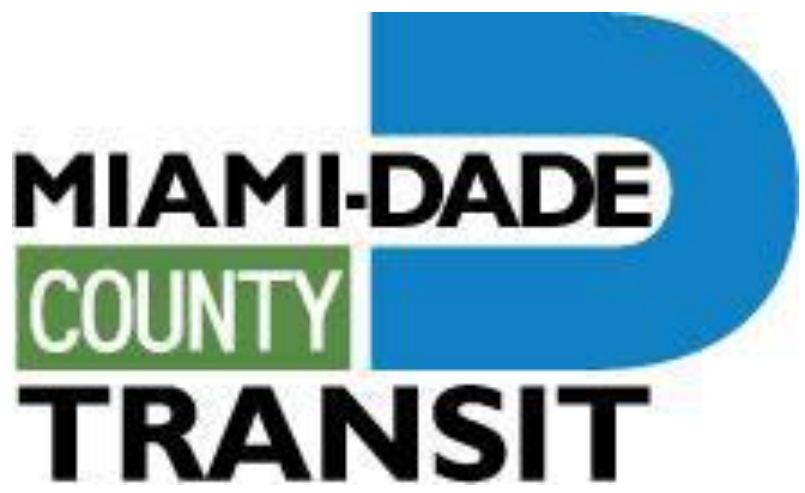

\section{EASY Card and Fare Overview}

In June 2008, MDT awarded Cubic Transportation Systems a contract to replace its 25 year old fare collection system. On October 29, 2009, MDT introduced the new AFCS following a 15-month installation and implementation process. The AFCS links MDT to other transit systems such as the City of Hialeah Transit, Conchita Transit Express (a private jitney service) and more recently, the

South Florida Regional Transportation Authority (SFRTA) through the integrated use of the EASY Card.

While the system as a whole is referred to as the EASY Card system, it includes multiple components: ticket vending machines (TVMs), ticket office machines (TOMs), point-of-sale units (POSU), validating fareboxes, faregates, central computing and data systems, a parking system and automatic passenger counters (APC).

South Florida currently uses two types of contactless smart card media: EASY Cards and EASY Tickets. The EASY Card is a plastic smartcard designed to last up to twenty years and can be used to store more than one type of media at a time. It also protects the card hold from fraud in the event a card is lost or stolen through balance protection registration. Additionally, EASY Cards can accommodate discounted fares and when a photo is affixed to the card, it can serve as a form of identification and proof of eligibility for certain fare discounts such as the Patriot Pass Program for honorably discharged Veterans. On the other hand, EASY Tickets are paper-based smartcard media designed to last up to 60 days. They can only store the original fare type first loaded, cannot be used for most discounted fare rates, and cannot be registered for loss or theft protection. 
The EASY Card and EASY Ticket allow passengers to pay their fares conveniently by simply tapping their cards on the farebox or fare gate which reads and deduct the appropriate value from the card or ticket.

Table 1-1 presents MDT's major fare categories prior to the introduction of the EASY Card system and Table 1-2 presents MDT's major fare categories post EASY Card implementation. The most notable changes associated with the introduction of EASY Card were related to the elimination of paper and magnetic transfers issued by bus drivers which were replaced by transfers encoded on the EASY Card. Tokens were eliminated and MDT also adopted a pay-per-boarding policy for cash customers without an EASY Card. These customers are now required to pay a full or reduced fare each time they board. EASY Card and EASY Ticket holders can transfer between buses free of charge and pay a discounted transfer fee for transfers between bus and rail modes.

Another feature offered through the system was the ability to load an electronic purse or a monetary value selected by the cardholder to make purchases. For example, a regular Metrorail customer who has a monthly Metrorail EASY Card may only occasionally use Metrorail parking, in which case the daily parking charge could be deducted from the electronic purse. The discounted transfer fees for transfers between bus and rail are also deducted from the electronic purse.

Table 1-1: Fare Structure Pre-EASY Card

\begin{tabular}{|l|c|c|}
\hline \multicolumn{1}{|c|}{ Fare Type } & Regular Fare & Reduced Fare \\
\hline Metrobus & $\$ 2$ (or one token) & $\$ 1.00$ \\
\hline Express Bus & $\$ 2.35$ (or one token $\$ 0.25)$ & $\$ 1.15$ \\
\hline Shuttle Bus & $\$ 0.25$ & $\$ 0.10$ \\
\hline Metrorail & $\$ 2.00$ & $\$ 1.00$ \\
\hline Metrorail Reduced-Fare Permit & Not Applicable & $\$ 0.65$ per month \\
\hline Metrorail Daily Parking Fee & $\$ 4.00$ & Not applicable \\
\hline Metrorail Monthly Parking Permit & $\$ 10.00$ & Not applicable \\
\hline Metromover & Free & Free \\
\hline Special Transportation Services (STS) & $\$ 3.00$ & $\$ 0.25$ \\
\hline Bus-to-Bus Transfer & $\$ 0.50$ & $\$ 0.25$ \\
\hline Bus-to-Express Bus Transfer & $\$ 0.50$ transfer $+\$ 0.35$ & $\$ 0.25$ transfer $+\$ 0.15$ \\
\hline Bus-to-Rail Transfer & $\$ 0.50$ & Not applicable \\
\hline Rail-to-Bus Transfer & $\$ 0.50$ & Not applicable \\
\hline Monthly Metropass & $\$ 100.00$ & Not applicable \\
\hline Discount Monthly Metropass & $\$ 50.00$ & Not applicable \\
\hline $\begin{array}{l}\text { Monthly Metropass Group Discount 5- } \\
99 \text { Passes }\end{array}$ & $\$ 90.00$ & Not applicable \\
\hline $\begin{array}{l}\text { Monthly Metropass Group Discount 100 } \\
+ \text { Passes }\end{array}$ & $\$ 85.00$ & $\$ 13.00$ \\
\hline College Metropass & $\$ 50.00$ & Free \\
\hline 7-Day Visitor Passport & $\$ 26.00$ & Not applicable \\
\hline Golden Passport or Patriot Passport & Free & \\
\hline One Roll of 10 Tokens & $\$ 19.50$ & \\
\hline
\end{tabular}

Source: MDT 2009 Transit Development Plan 
Table 1-2. MDT Current Fare Structure

\begin{tabular}{|c|c|c|}
\hline Bus & Regular Fare & Reduced Fare \\
\hline Metrobus & $\$ 2.00$ & $\$ 1.00$ \\
\hline Express Bus & $\$ 2.35$ & $\$ 1.15$ \\
\hline Shuttle Bus & $\$ 0.25$ & $\$ 0.15$ \\
\hline Bus-to-Bus Transfer & Free & Free \\
\hline Bus-to-Express Bus Transfer & $\$ 0.50+\$ 0.35$ Upgrade & $\$ 0.25+\$ 0.15$ Upgrade \\
\hline Bus-to-Rail Transfer & $\$ 0.50$ & $\$ 0.25$ \\
\hline Rail-to-Bus Transfer & $\$ 0.50$ & $\$ 0.25$ \\
\hline Shuttle Bus-to-Bus or Rail Transfer & $\$ 1.75$ & $\$ 0.90$ \\
\hline Shuttle Bus-to-Express Bus Transfer & $\$ 2.10$ & $\$ 1.05$ \\
\hline Rail & Fare & Discount Fare \\
\hline Metrorail & $\$ 2.00$ & $\$ 1.00$ \\
\hline Metrorail Daily Parking Fee & $\$ 4.00$ & Not Applicable \\
\hline Metrorail Monthly Parking Permit & $\begin{array}{c}\$ 10.00 \text { (with purchase of } \\
\text { monthly pass) }\end{array}$ & Not Applicable \\
\hline Discounts & Fare & Discount Fare \\
\hline 1-Month Pass & $\$ 100.00$ & $\$ 50.00$ \\
\hline $\begin{array}{l}\text { 1-Month Pass-Group Discount } \\
\text { 4-99 Passes }\end{array}$ & $\$ 90.00$ & Not Applicable \\
\hline $\begin{array}{l}\text { 1-Month Pass-Group Discount } \\
100 \text { or More Passes }\end{array}$ & $\$ 85.00$ & Not Applicable \\
\hline 7-Day Pass & $\$ 26.00$ & $\$ 13.00$ \\
\hline 1-Day Pass & $\$ 5.00$ & $\$ 2.50$ \\
\hline College/Adult Educations Monthly Pass & $\$ 50.00$ & Not Applicable \\
\hline Golden Passport/Patriot Passport & Free & Free \\
\hline Special Transportation Services & $\$ 3.00$ & Not Applicable \\
\hline Other & Fare & Discount \\
\hline Metromover & Free & Free \\
\hline EASY Card & $\$ 2.00$ & Not Applicable \\
\hline EASY Ticket & Free & Free \\
\hline
\end{tabular}

Source: MDT Website 


\section{EASY Card System Rollout}

Given the complexity of the MDT fare structure and the planned introduction of the new technology, MDT developed a phased approach to rollout. Equipment installation took place in two phases. Phase 1 included the new central computer system (CCS), the bus garage computer, bus vaulting equipment and bus fareboxes. This phase had little or no impact on customers because existing fare products, policies and procedures remained in place throughout the installation. During Phase 1:

- EASY Cards were not used.

- All monthly magnetic passes were presented to MDT bus operators or "flashed" by patrons for entry onto the bus.

- Tokens were validated and accepted.

- All coins except pennies were validated and accepted.

- $\$ 1, \$ 2, \$ 5, \$ 10$ and $\$ 20$ bills were validated and accepted.

- Paper tear-off transfers were issued and accepted by drivers.

- Magnetic transfers were issued and accepted by drivers.

The rail system installation took place in Phase 2 which included TVMs, faregates, TOMs and the introduction of EASY Cards, new fare products, POSUs and other hardware and software components. Highlights of Phase 2 included:

- EASY Cards and EASY Tickets were available for purchase at TVMs, TOMs and via the internet.

- All existing and new fare products were encoded on EASY Cards to integrate bus, rail and parking.

- Paper and magnetic transfers were eliminated. Patrons without an EASY Card were required to pay a full or reduced fare for each boarding.

- For customers beginning their journey on Metrorail, transfers were valid for three hours.

- Metrorail parking payment via EASY Card was introduced.

- Sales outlets with the full capability to issue and register EASY Cards and load and re-load fare projects were introduced.

- All flash passes were discontinued.

- 1-Day and 7-Day rolling passes were introduced.

- A post-introductory EASY Card fee of $\$ 2.00$ was established and EASY Tickets continued to be offered free of charge.

- A consistent transfer policy of two transfers to be used within three hours for bus and rail was established.

- Metrorail customers were required to have an EASY Card.

- The sale of tokens was discontinued.

To facilitate the transition to the new AFCS, MDT developed a detailed customer service business plan to ensure maximum coordination among all internal stakeholders impacted by the new system. The business plan focused on efforts to ensure external customers receive education and communication about the new system, acquire the fare products appropriate to their needs, and maximize convenience and accessibility to the MDT network. 
MDT began preliminary outreach efforts to notify the public of the upcoming changes to the fare collection system as early as 2008. A "coming soon" informational campaign was conducted to reach customers at train stations, bus bays, inside buses and rail vehicles, at bus stops and at transit service centers. The pre-deployment activities included:

- Production of brochures, pocket folders, posters, giveaways and bookmarks in English, Spanish and Creole

- Application of notification decals on all Metrorail turnstiles and bus fareboxes

- Production of an EASY Card customer information newsletter

- Distribution of the EASY Card newsletter to the Corporate Discount Program customer database

- Conducting outreach activities at Metrorail stations and major transit hubs

- Advertising on buses, trains, business centers, vehicles and transfer centers

- Utilization of mock TVMs for training at terminals, rail stations and public events

- Conducting a media campaign consisting of 30-second commercials airing on local and public access television stations

- Print advertisements in all major circulation and community newspapers.

The phased implementation for customers began with Golden Passport and Patriot Passport customers conversion to EASY Card. Miami-Dade County residents who are 65 years and older and are Social Security beneficiaries are entitled to ride MDT services free of charge. Specialized strategies to educate Golden Passport customers included:

- Production of large type informational materials in English, Spanish and Creole

- Distribution of advance mail notices

- Distribution of "how-to-use" informational materials

- Establishment of a multi-lingual customer support telephone number

- Conducting of outreach activities at senior centers and housing complexes

- Distribution of free EASY Cards with photo ID upon annual renewal and recertification.

Honorably-discharged veterans who are residents of Miami-Dade County and have an annual income of $\$ 22,000$ or less may ride MDT services free of charge with a Patriot Passport. MDT contacted these customers and encouraged them to apply for recertification to receive new EASY Cards. MDT also worked cooperatively with the Veterans Administration to contact other qualified veterans who historically have been difficult to reach by mail.

Because the conversion from Golden and Patriot Passports commenced before full implementation of the fare system, Passport eligible passengers were required to "flash" their EASY Card or EASY Ticket to security and fare collection personnel prior to boarding.

Prior to implementation, MDT also made approximately 500,000 free EASY Cards available for distribution to the general public beginning September 28, 2009, to facilitate the transition to the new system.

In preparation for EASY Card implementation, the business plan also detailed the extensive MDT staff training plans and requirements ranging from the AFCS equipment, account 
management, dispute resolution, report generation and online sales. A new Station Services unit was created with staff dedicated to helping customers use the AFCS at the point of fare media purchase and use at major stations, terminals, and transfer points. Representatives from this unit were initially part of the overall introduction of the AFCS and, with the support of other MDT staff and an extensive network of volunteers, provided one-on-one customer assistance at MDT stations and bus facilities 24/7 for approximately 16 weeks following EASY Card implementation. 


\section{Chapter 2}

\section{Sales and Transaction Data}

\section{Sales at Ticket Vending Machines}

In the original procurement, MDT purchased 62 full service (cash, credit and debit) and 34 cashless TVMs. TVMs are located at all 23 Metrorail stations as well as one at the Adrienne Arsht MetroMover Station and the South Dade Justice Center. For this analysis, the TVM located at Golden Glades Park \& Ride is included with the 23 Metrorail stations as a major sales location. Figure 2-1 to the right displays

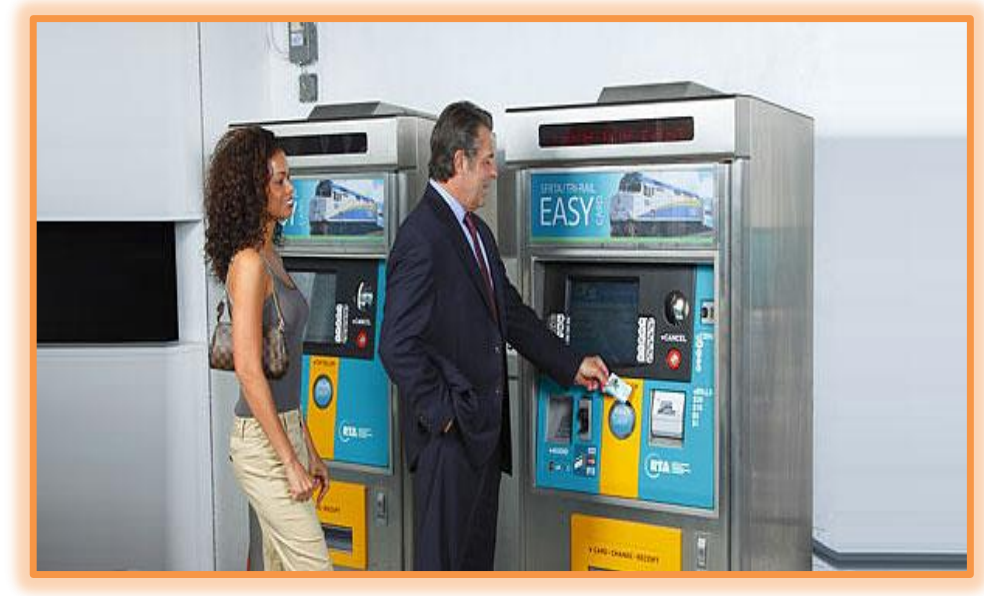

Figure 2-1: Ticket Vending Machines a TVM. TVMs are by far the most popular, most utilized, and highest selling sales outlets in the Miami-Dade Transit system with total sales of $\$ 84.82$ million from 2010 to 2012 . Sales at TVMs increased from $\$ 24.5$ million in 2010 , to $\$ 28.8$ million in 2011 , and $\$ 31.5$ million in 2012.

\section{Annual TVM Sales Broken Down by Transactions for EASY Cards and EASY Tickets}

EASY Tickets out-sold EASY Cards in all three years from 2010 to 2012. In 2010, there were 1.79 million EASY Card transactions while there were 1.99 million EASY Ticket transactions. Three year cumulative transactions include 6,080,857 EASY Card and 7,627,273 EASY Ticket transactions for a total of 13,708,130 total transactions, as shown in Figure 2-2. 


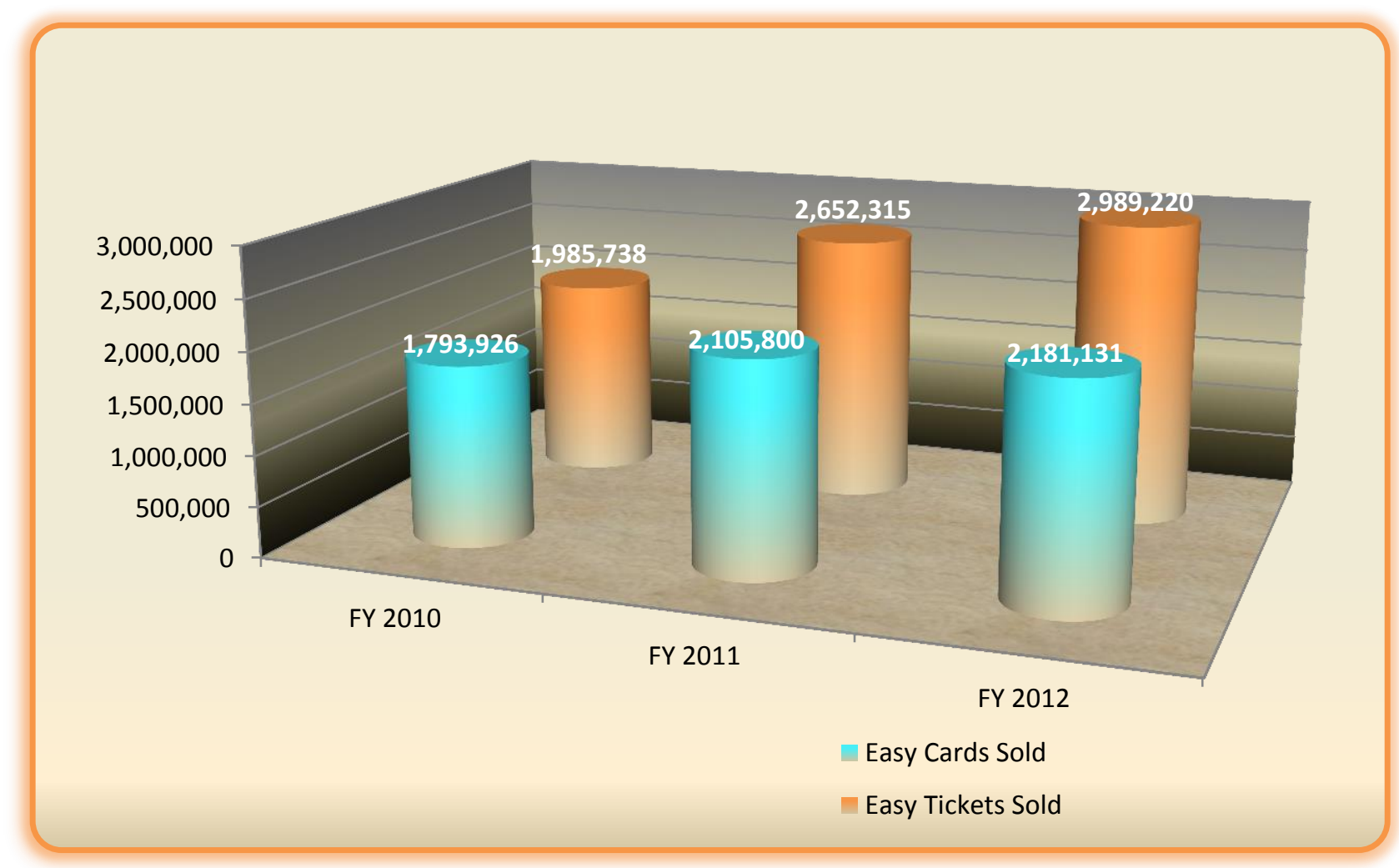

Figure 2-2. Annual Ticket Vending Machines (TVM) Sales Broken Down by Transactions for EASY Cards vs. EASY Tickets (FY 2010 - FY 2012) 


\section{Total Annual TVM Sales}

Total sales for TVMs were $\$ 84.82$ million for the three years from 2010 to 2012. In 2010, total sales were $\$ 24.82$ million increasing to $\$ 28.77$ million in 2011 , a 17.1 percent increase. In 2012, total sales were $\$ 31.50$ million, a 9.5 percent increase over 2011 . Figure 2-3 below displays total annual TVM sales, 2010-2012.

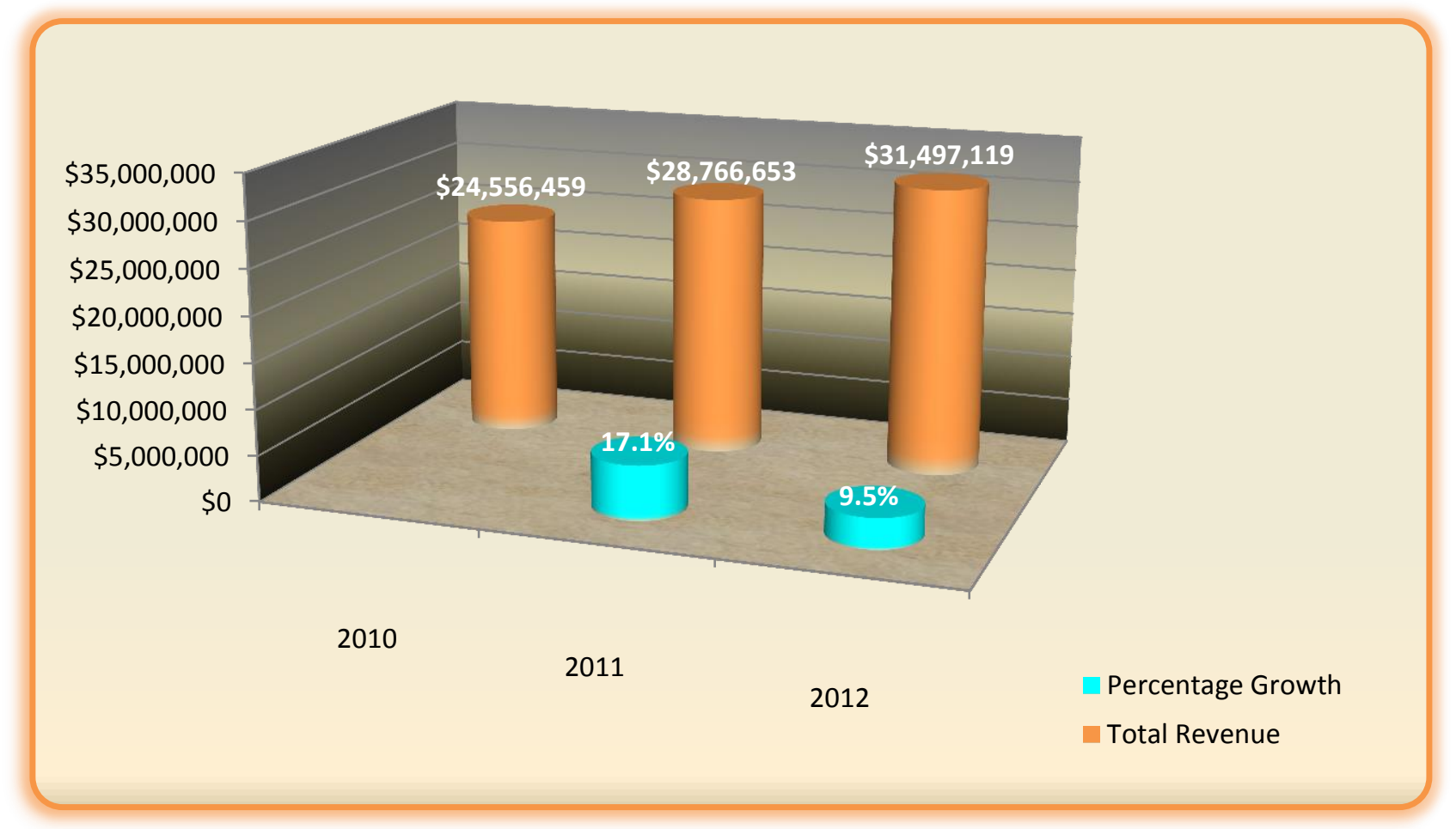

Figure 2-3. Annual Ticket Vending Machines (TVM) Sales (FY 2010 - FY 2012) 


\section{Average Revenue per Transaction}

With $\$ 84.82$ million in total sales for $13,708,131$ transactions, the average revenue per transaction was $\$ 6.18$. This average revenue per transaction is significantly lower than the average for TOMs, which was $\$ 27.25$.

\section{Annual TVM Sales by Form of Payment}

The forms of payment accepted on TVMs are cash and credit/debit card although some TVMs are cashless. Cash is still the most utilized form of payment; however, credit/debit card transactions increased between 2010 and 2012. For the three-year period, cash sales totaled $\$ 64.8$ million and credit/debit cards accounted for $\$ 19.1$ million in sales. Figure $2-4$ below displays the annual TVM sales by form of payment.

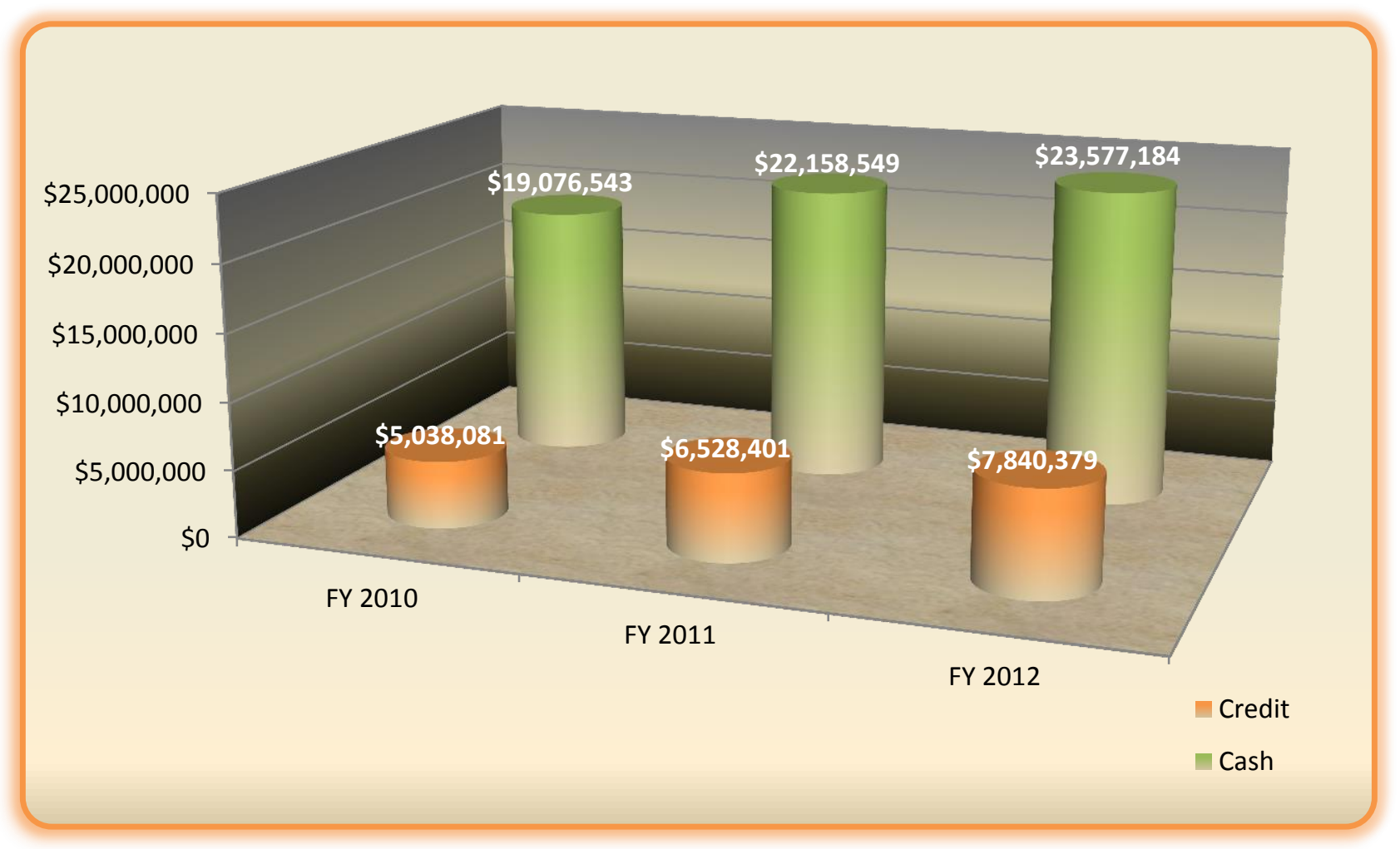

Figure 2-4. Annual TVM Sales by Form of Payment (FY 2010- FY 2012) 


\section{Three Year Cumulative Total of Sales at Metrorail Stations and Golden Glades}

Government Center had the highest sales at $\$ 14.5$ million for the three-year period. Dadeland South had $\$ 8.5$ million in cumulative TVM sales while Dadeland North had $\$ 7.3$ million. Brickell had $\$ 6.9$ million in TVM sales and Douglas Road had $\$ 5.2$ million. Seven of the top selling stations are located at Government Center or south of Government Center. Top-selling stations north of Government Center include the Civic Center, Allapattah, and Northside. The top 10 TVM sales stations account for 70 percent of all TVM sales.

Figure 2-5 below is a system map displaying the locations of all Metrorail stations and Figures 2-6 and 2-7 display the cumulative sales at Metrorail stations between 2010 and 2012. 
Palmetto

(P)

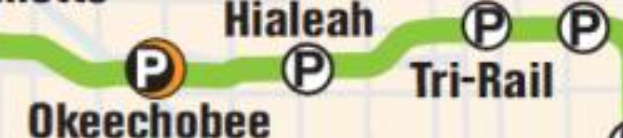

(PDr. Martin Luther King Jr.

\section{Brownsville (P)}

\section{Earlington Heights}

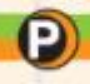

(P) Allapattah

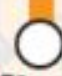

Miami

International

Airport
(P) Santa Clara

Civic Center

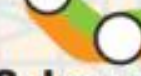

Culmer

Historic Overtown/ Lyric Theatre

Government Center

Brickell

\section{Vizcaya}

\section{Coconut Grove}

\section{(P)}

\section{Douglas Road}

\section{University}

P

South Miami

(P)

Dadeland North

Dadeland South

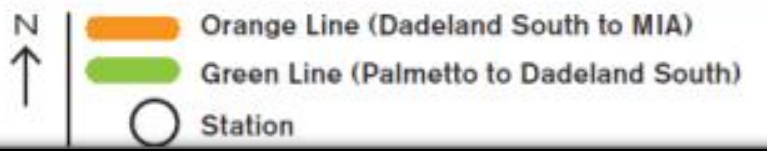

Figure 2-5. Metrorail System Map 


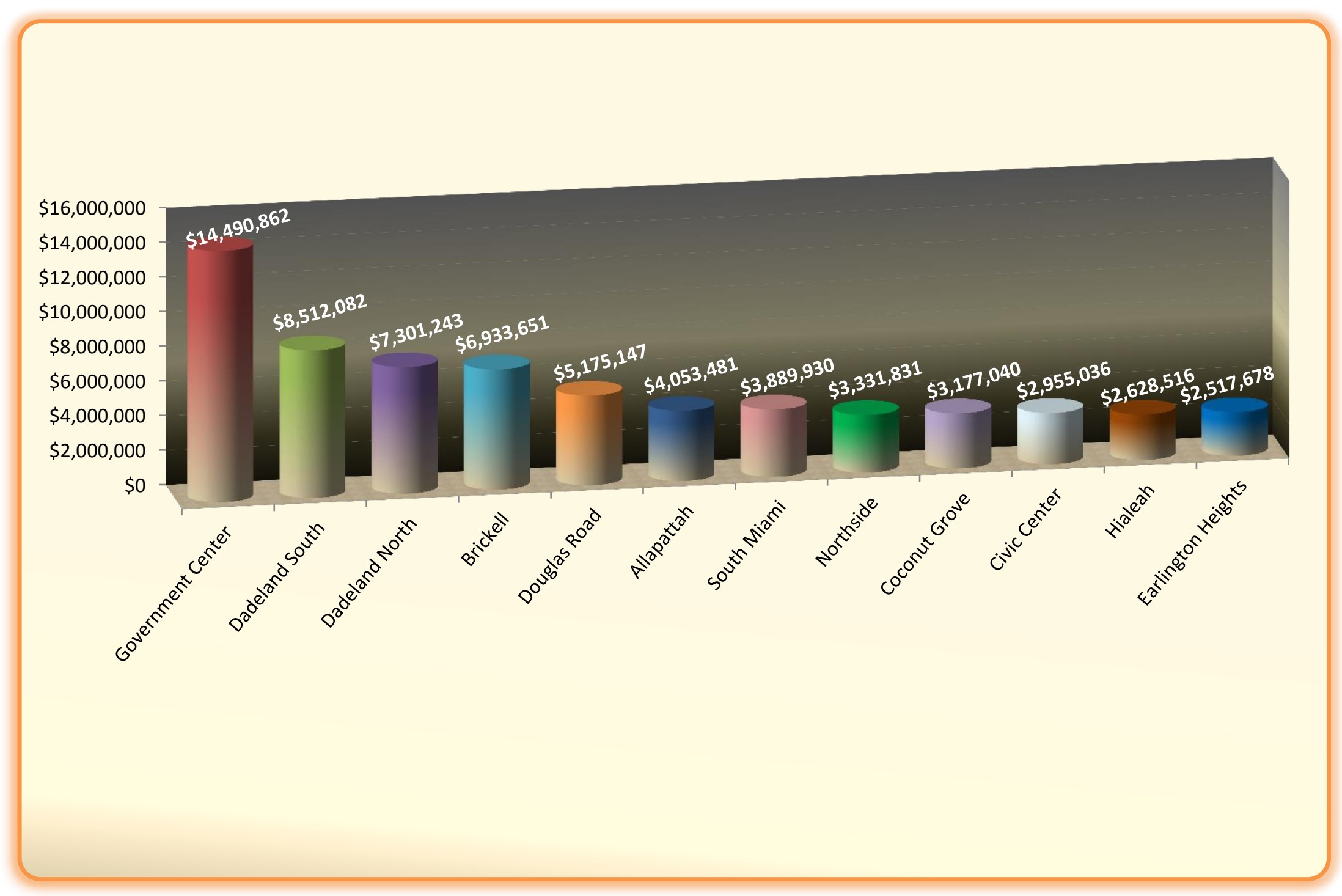

Figure 2-6. TVM Sales, Metrorail, Top 12 Highest Selling Stations: 2010-2012, Cumulative 


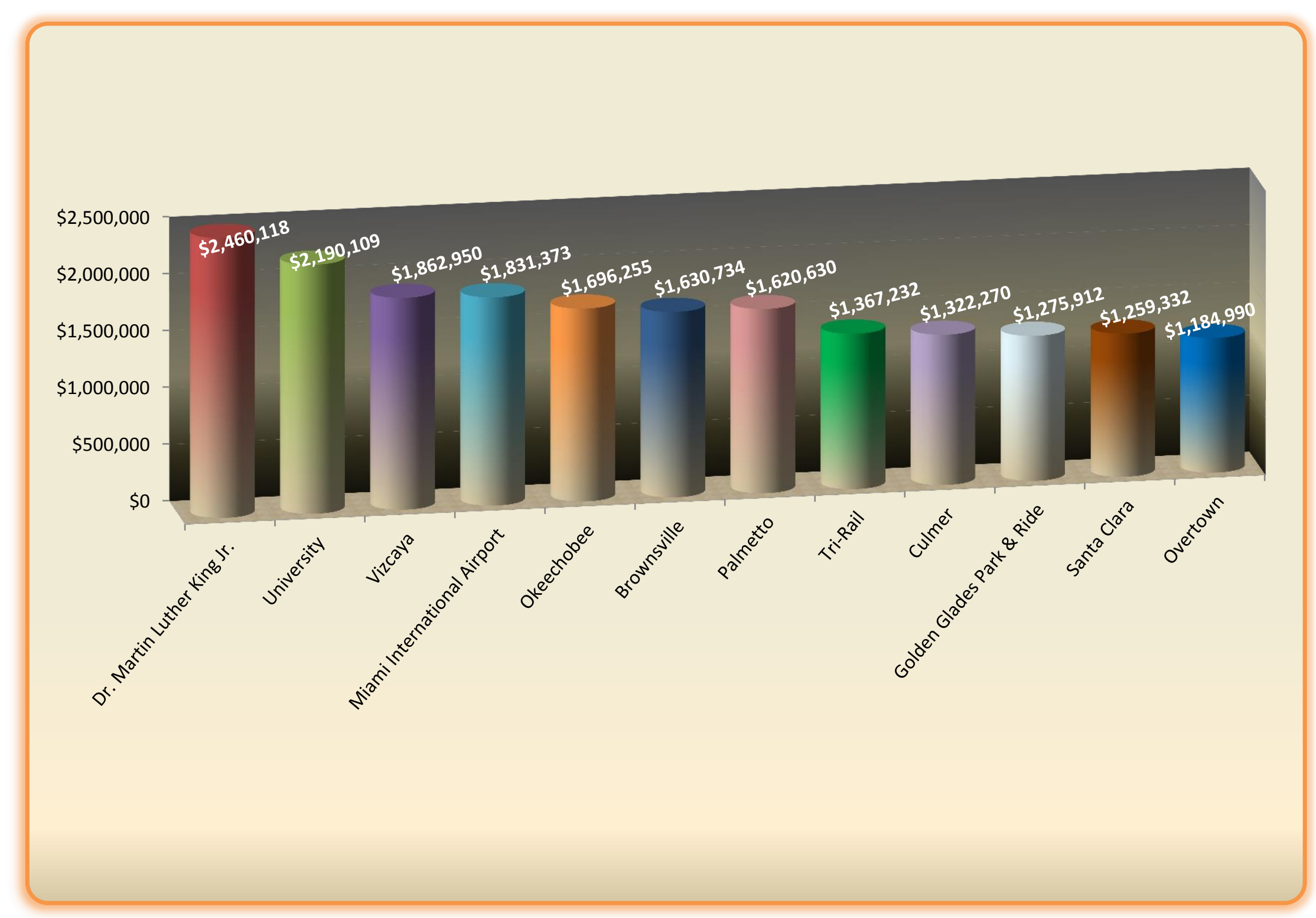

Figure 2-7. TVM Sales, Metrorail, Sales of Remaining Stations: 2010-2012, Cumulative 


\section{Annual Sales at Metrorail Stations and Golden Glades}

In 2010, there were eight Metrorail stations wherein sales at TVMs exceeded $\$ 1$ million. Those stations were Government Center, Dadeland South, Dadeland North, Brickell, Douglas Road, Allapattah, South Miami and Northside. The remaining stations had sales ranging from $\$ 137,000$ to $\$ 932,000$. Figures 2-8 and 2-9 display sales by station for 2010 .

By 2011, there were nine stations with TVM sales greater than $\$ 1$ million in sales with Coconut Grove joining the eight stations identified above. The remaining stations had total sales ranging from $\$ 339,000$ to $\$ 983,000$. Figures $2-10$ and $2-11$ display sales by station for 2011.

By 2012, the Civic Center had TVM sales that exceeded $\$ 1$ million for a total of 10 stations with sales greater than $\$ 1$ million. The remaining stations had sales ranging from $\$ 457,000$ to $\$ 989,000$. All stations experienced an annual growth in sales over the three year period. Figures 2-12 and 2-13 below display sales by station for 2012 .

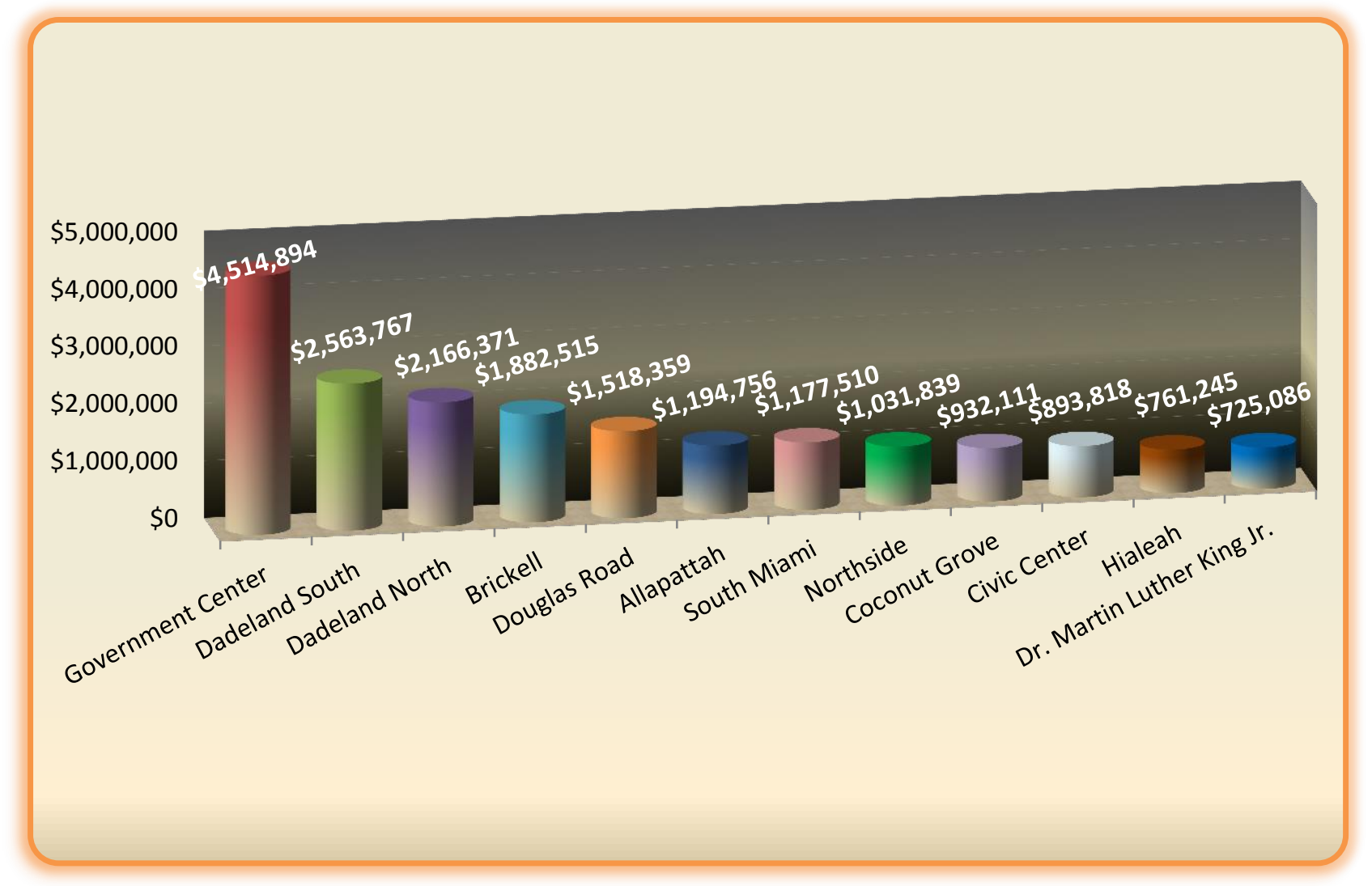

Figure 2-8. TVM Sales, Metrorail, Top 12 Highest-Selling Stations: FY 2010 


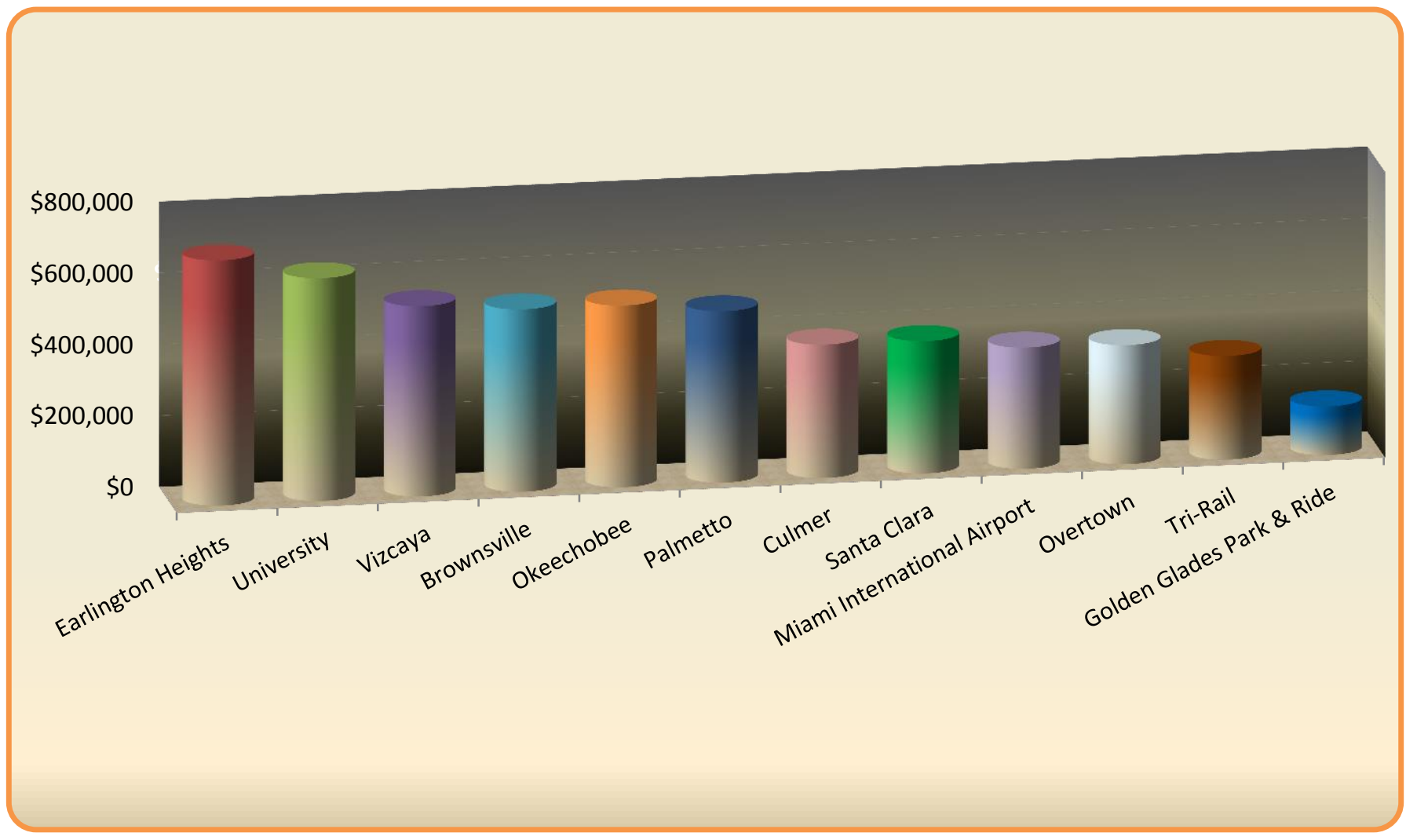

Figure 2-9. TVM Sales, Metrorail, Sales of Remaining Stations: FY 2010

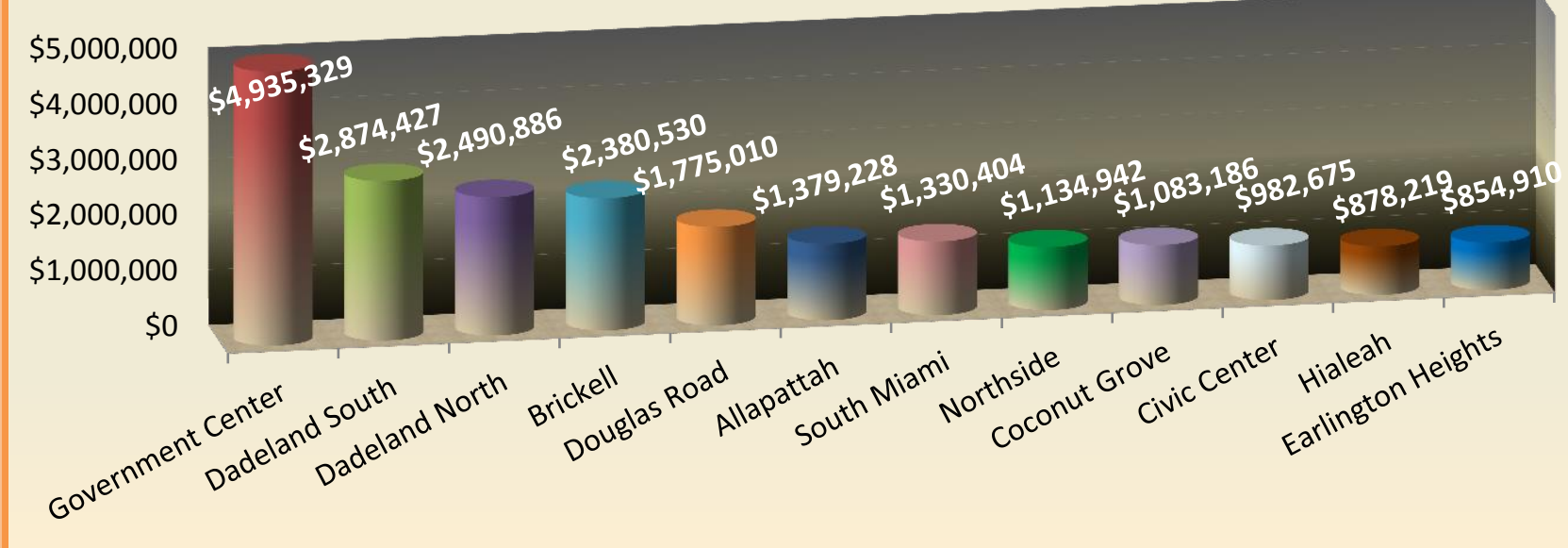

Figure 2-10. TVM Sales, Metrorail, Top 12 Highest Selling Stations: FY 2011 


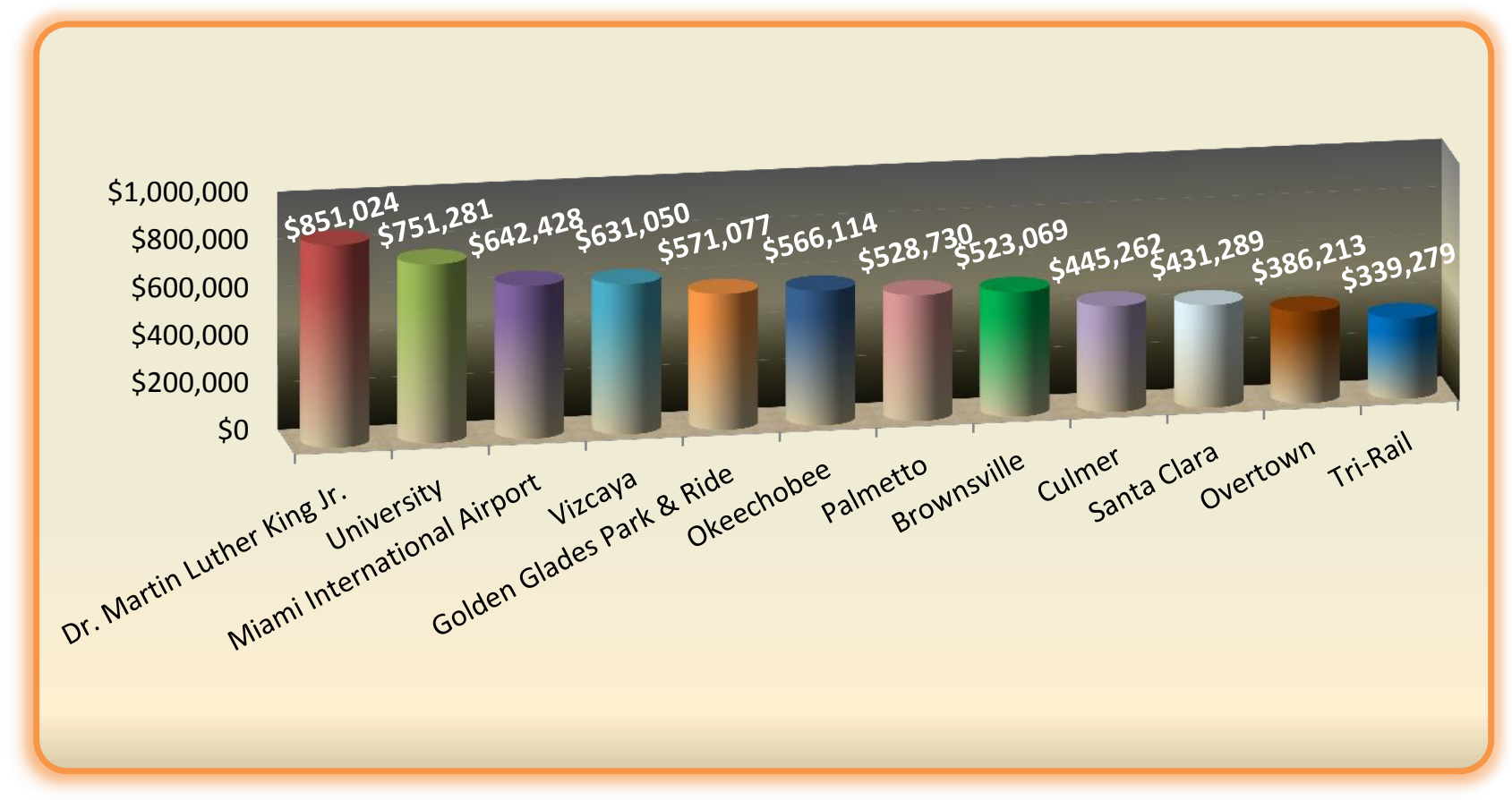

Figure 2-11. TVM Sales, Metrorail, Sales of Remaining Stations: FY 2011

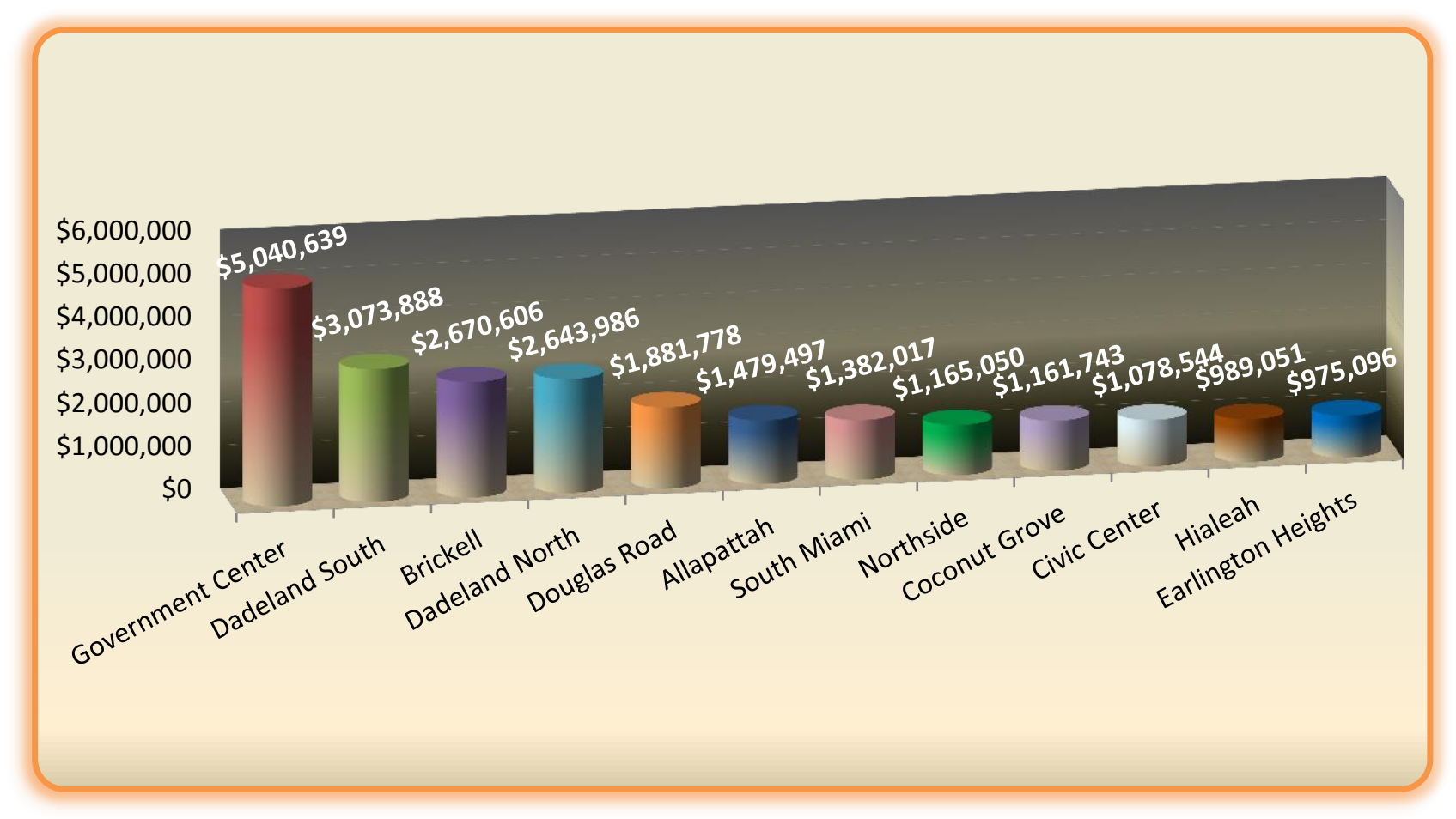

Figure 2-12. TVM Sales, Metrorail, Top 12 Highest Selling Stations: FY 2012 


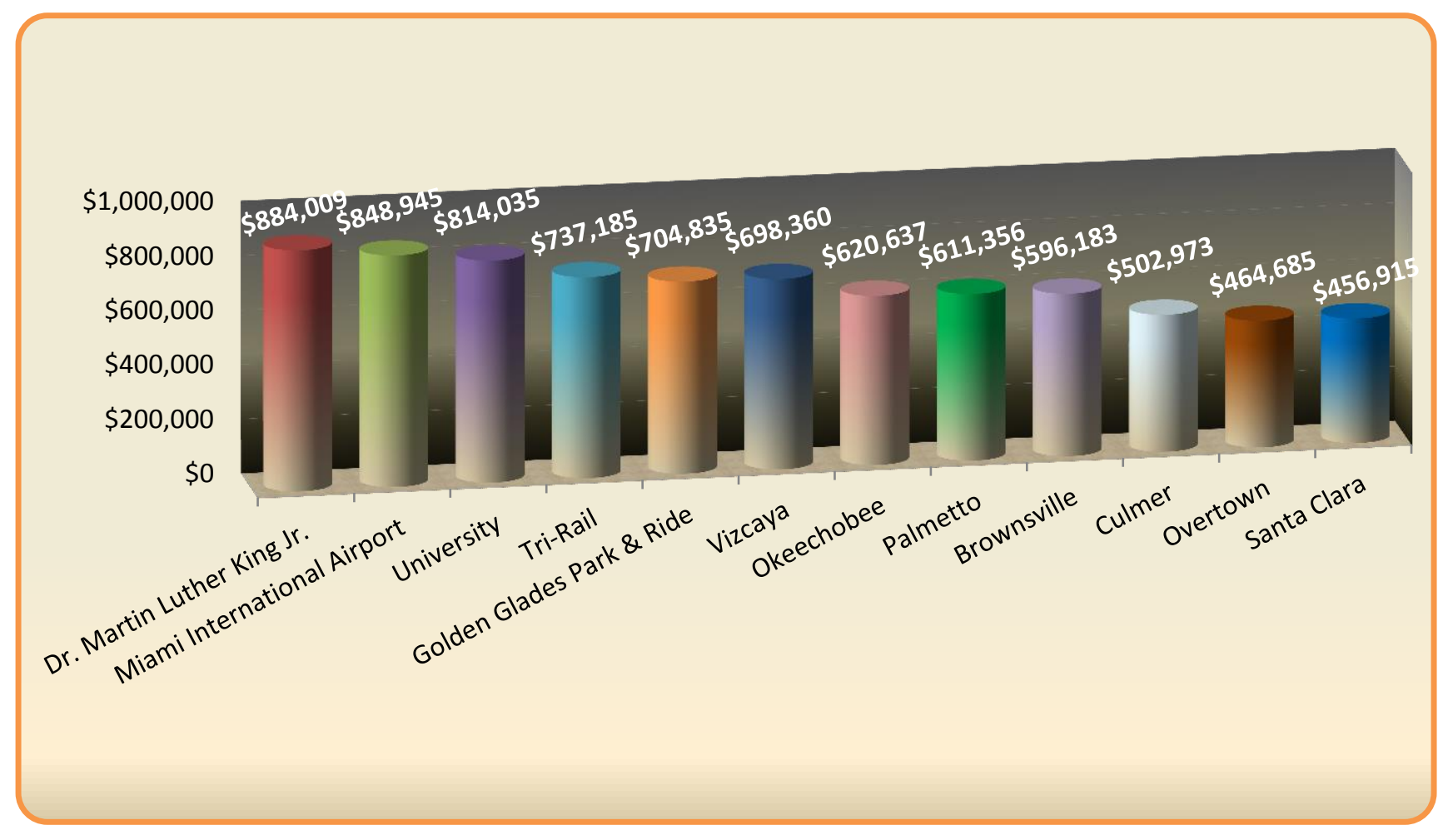

Figure 2-13. TVM Sales, Metrorail, Sales of Remaining Stations: FY 2012

\section{Sales at Ticket Office Machines}

Miami-Dade Transit purchased four TOMs in the original procurement. TOMs are different than TVMs because they are used at personally staffed sales outlets. Government Center, the North Dade Justice Center, the Miami-Dade Permitting and Inspection Center, and the Revenue Office each had one TOM. According to MDT's website, the two remote TOMs have limited sales capability. For instance, EASY Cards and EASY Tickets are not available for purchase but customers can reload an existing pass. Also, no cash is accepted and no discounted fare purchases can be made. Fare purchases are only available for full-fare paying customers. However, based on the data supplied by MDT, these limitations do not apply to the TOM at Government Center. Below is data regarding sales at TOMs from 2010 to 2012 .

\section{Sales of EASY Cards and EASY Tickets}

Over the three-year period, there were 306,609 EASY Card and 178,475 EASY Ticket transactions at TOMs, inclusive of parking. Because of the initial roll-out, sales in 2010 were higher than 2011 or 2012; however, sales in 2012 exceeded sales in 2011. In 2012, there were 99,658 EASY Cards and 58,176 EASY Tickets sold at TOMs. Figure 2-14 below displays the breakdown of sales by year. 


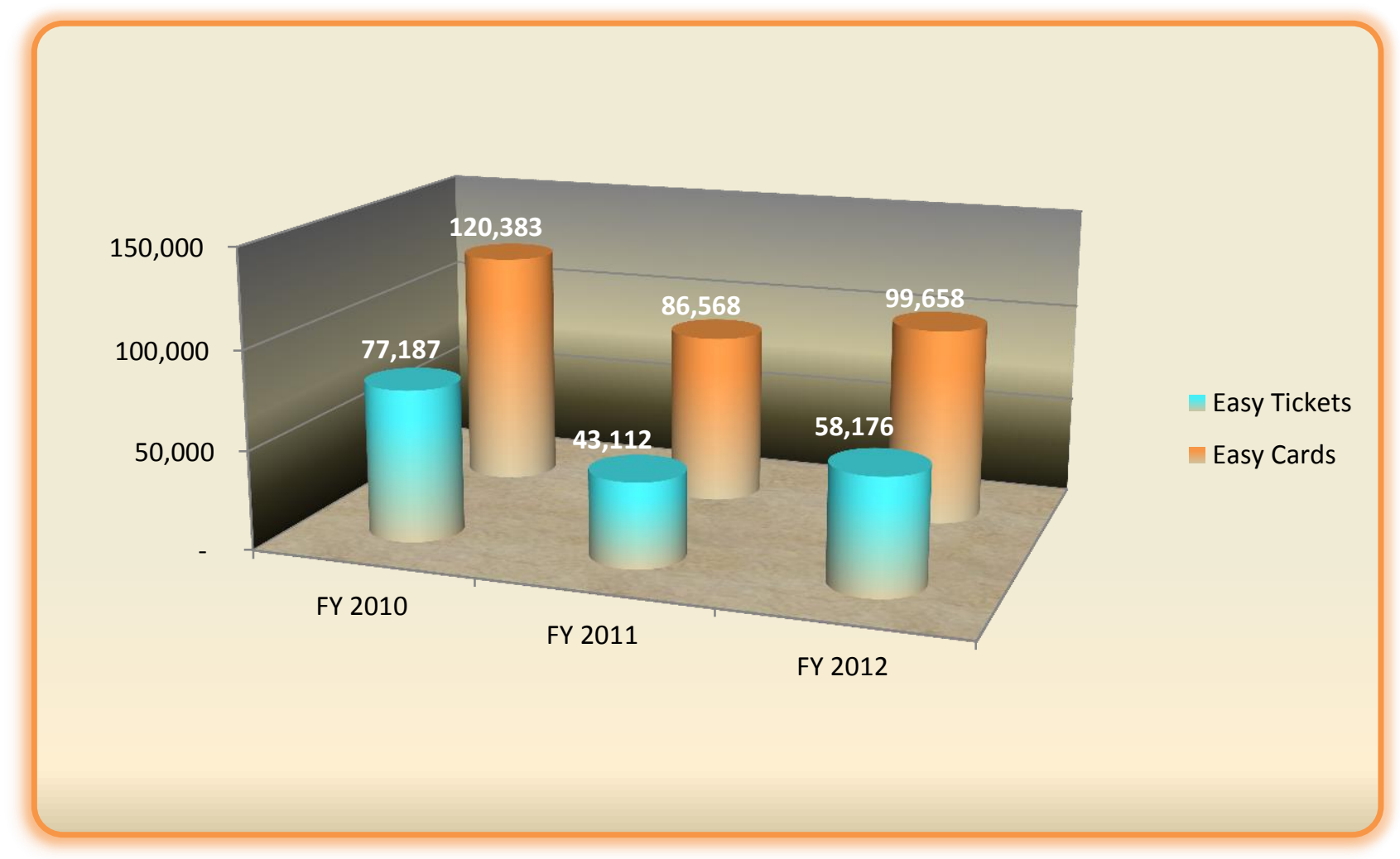

Figure 2-14. Annual Ticket Office Machines (TOM) Sales Broken Down by EASY Card and EASY Ticket Transactions (FY 2010 - FY 2012)

\section{Annual TOM Sales}

Total sales for the three-year period were $\$ 13.2$ million, with most of those sales occurring at Government Center. Sales peaked in 2010 at $\$ 5.1$ million, dipped to $\$ 3.9$ million in 2011, and increased to $\$ 4.12$ million in 2012 , a two-percent increase over 2011 . Figure 2-15 below displays total sales by year, inclusive of parking. 


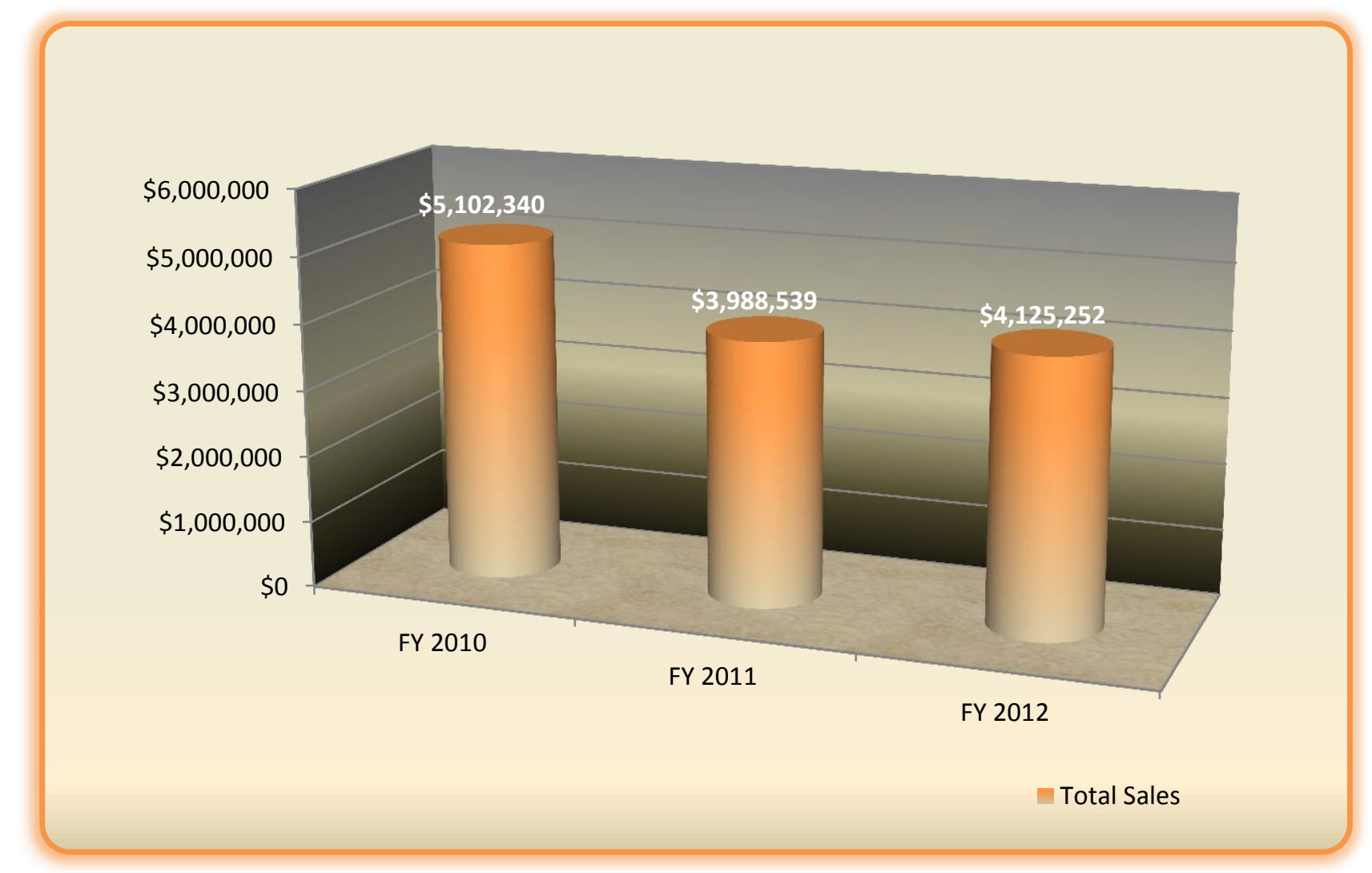

Figure 2-15. Annual TOM Sales (FY 2010 - FY 2012)

\section{Annual TOM Sales by Form of Payment}

The three forms of payment are cash, check and credit card. In 2010, TOMs processed $\$ 2.2$ million in cash transactions. By 2011 cash transactions declined to $\$ 1.6$ million and increased in 2012 to $\$ 1.7$ million. Payment by check increased from $\$ 1.3$ million in 2010 to $\$ 1.7$ million in 2011 , but declined to $\$ 906,808$ in 2012 . On the other hand, credit card transactions experienced a dramatic increase from $\$ 564,519$ in 2010 to $\$ 1.5$ million in 2012, a 166 percent increase. Figure 2-16 below displays the annual TOM sales by form of payment. 


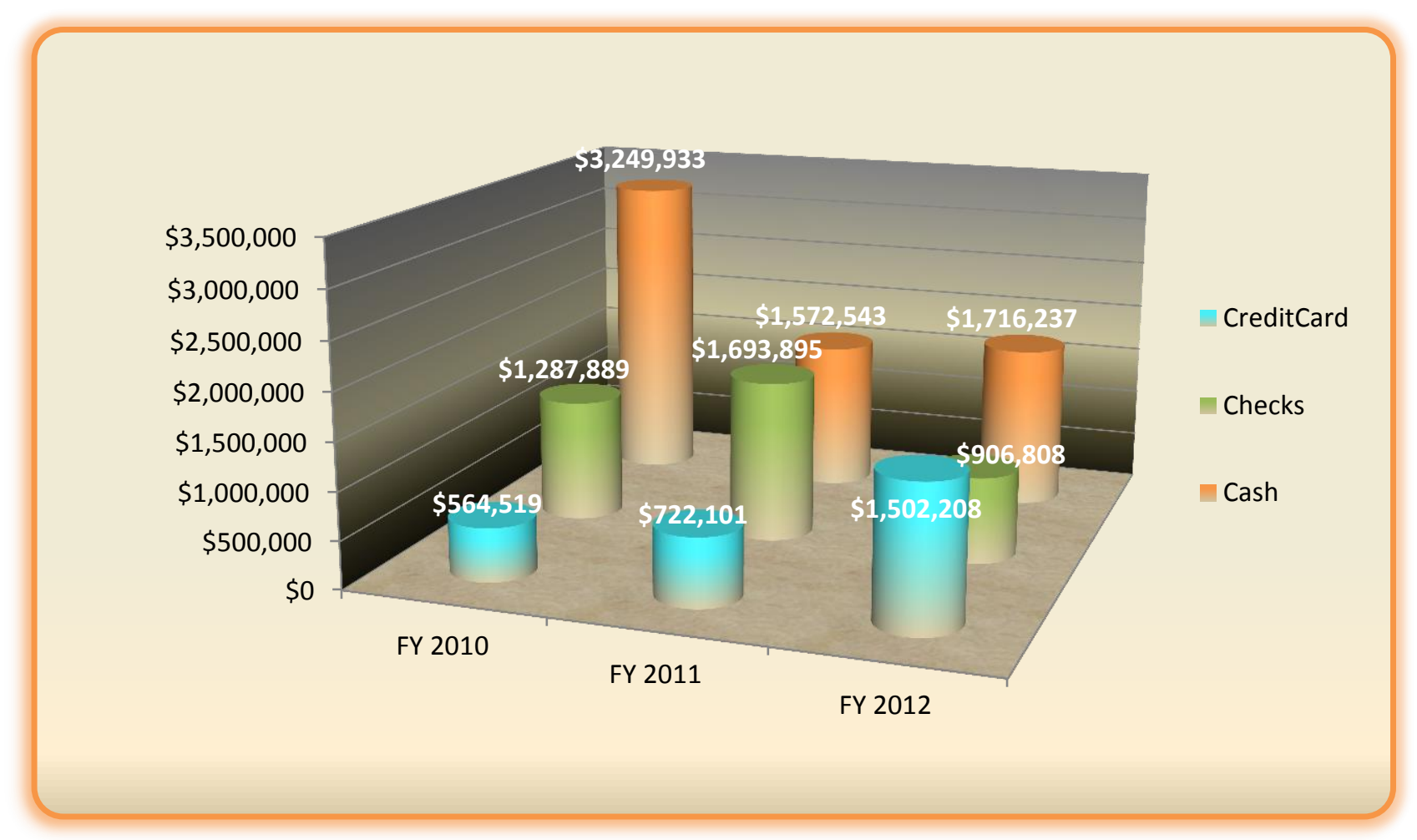

Figure 2-16. Annual TOM Sales by Form of Payment (FY 2010- FY 2012)

\section{Average Revenue per Transaction}

The total transactions for EASY Card, EASY Ticket and parking were 485,084 and total revenue was $\$ 13.2$ million or an average revenue per transaction of $\$ 27.85$. In 2010 , there were 197,570 transactions that generated $\$ 5.1$ million in revenue, or an average of $\$ 25.82$ per transaction. In 2011, there were 129,680 transactions with revenue of $\$ 4.0$ million, or an average of $\$ 30.75$ per transaction. The 157,834 transactions that occurred in 2012 generated revenue of $\$ 4.1$ million, for an average $\$ 26.13$ per transaction.

\section{Sales by Month}

In FY 2010, sales during the first three months of the AFCS roll-out totaled $\$ 3.0$ million. The 2010 sales, however, dropped from January to July and picked up again in the months of August and September when sales averaged about $\$ 340,000$ per month. In the remaining months, sales dropped to between $\$ 166,000$ and $\$ 230,000$ per month until August and September when monthly sales averaged about $\$ 340,000$ per month (Figure $2-17$ ). In 2011, sales averaged $\$ 332,378$ per month (Figure 2-18) and by 2012 sales averaged $\$ 343,771$ per month (Figure 2-19). With the exception of early FY 2010, no significant TOM seasonal sales fluctuations occurred during the three year period. Although sales trended somewhat higher in late FY 2010 and 2011, there was a slight decline in FY 2012. 


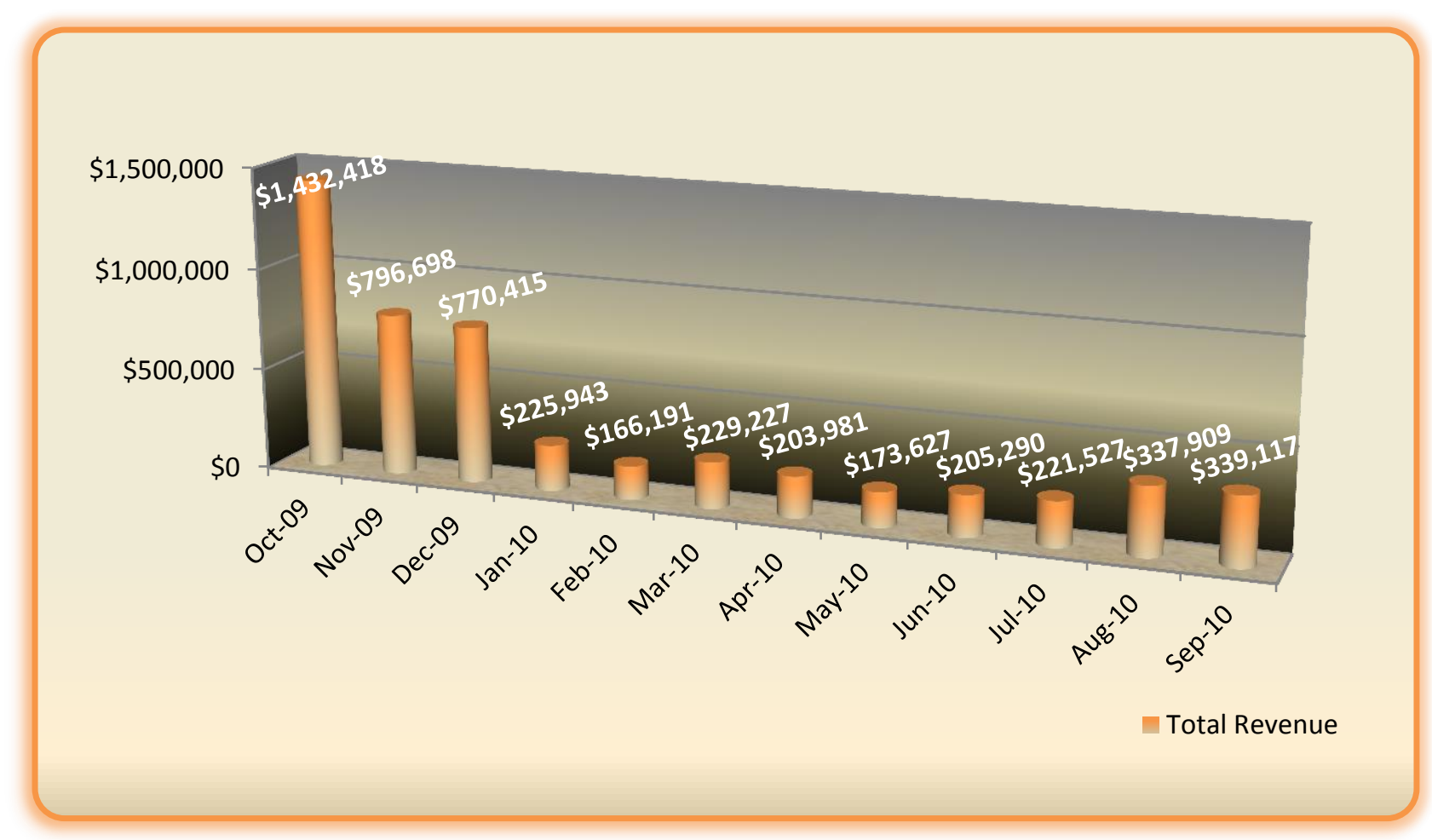

Figure 2-17. TOM Sales Revenue: FY 2010

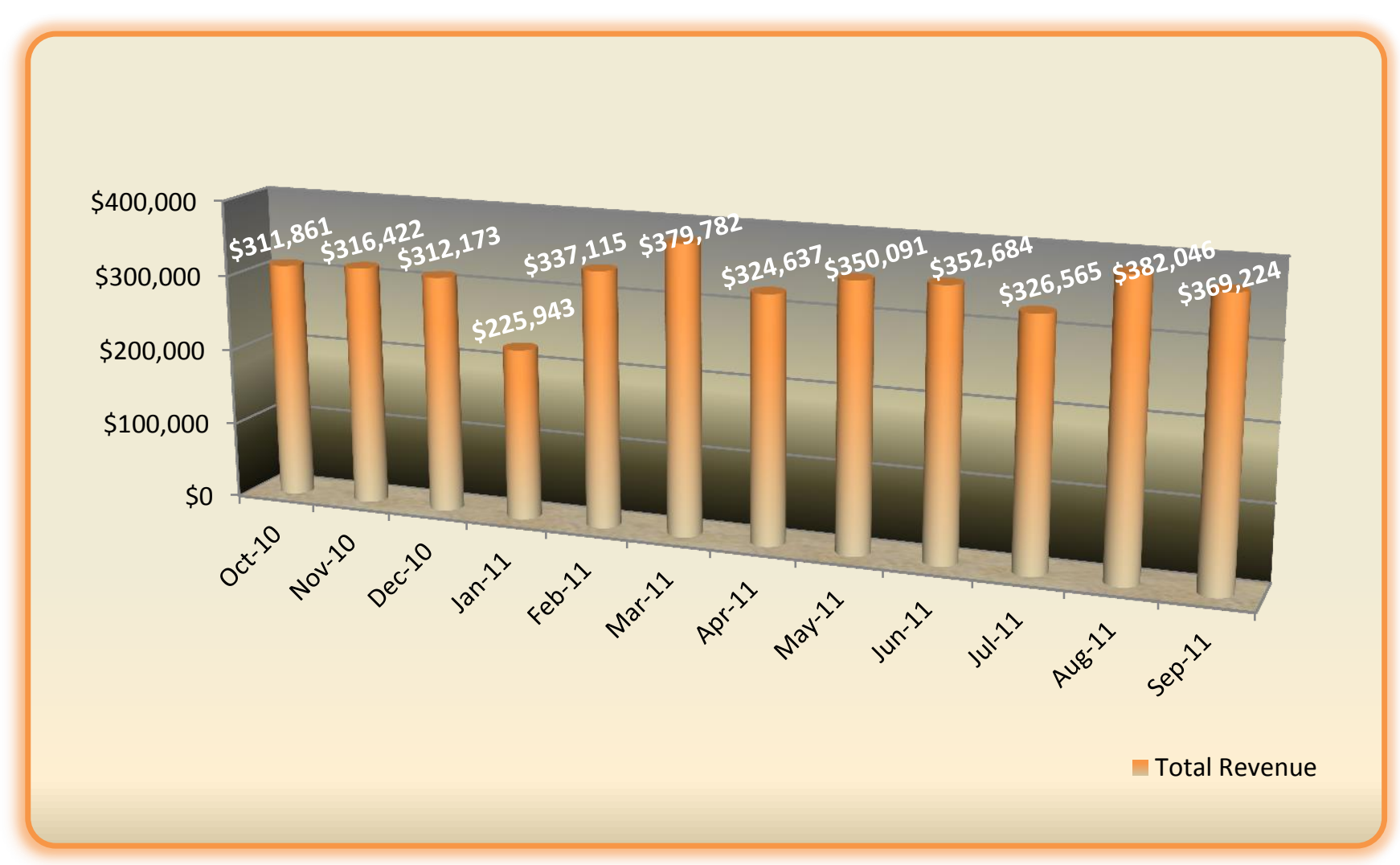

Figure 2-18. TOM Sales Revenue: FY 2011 


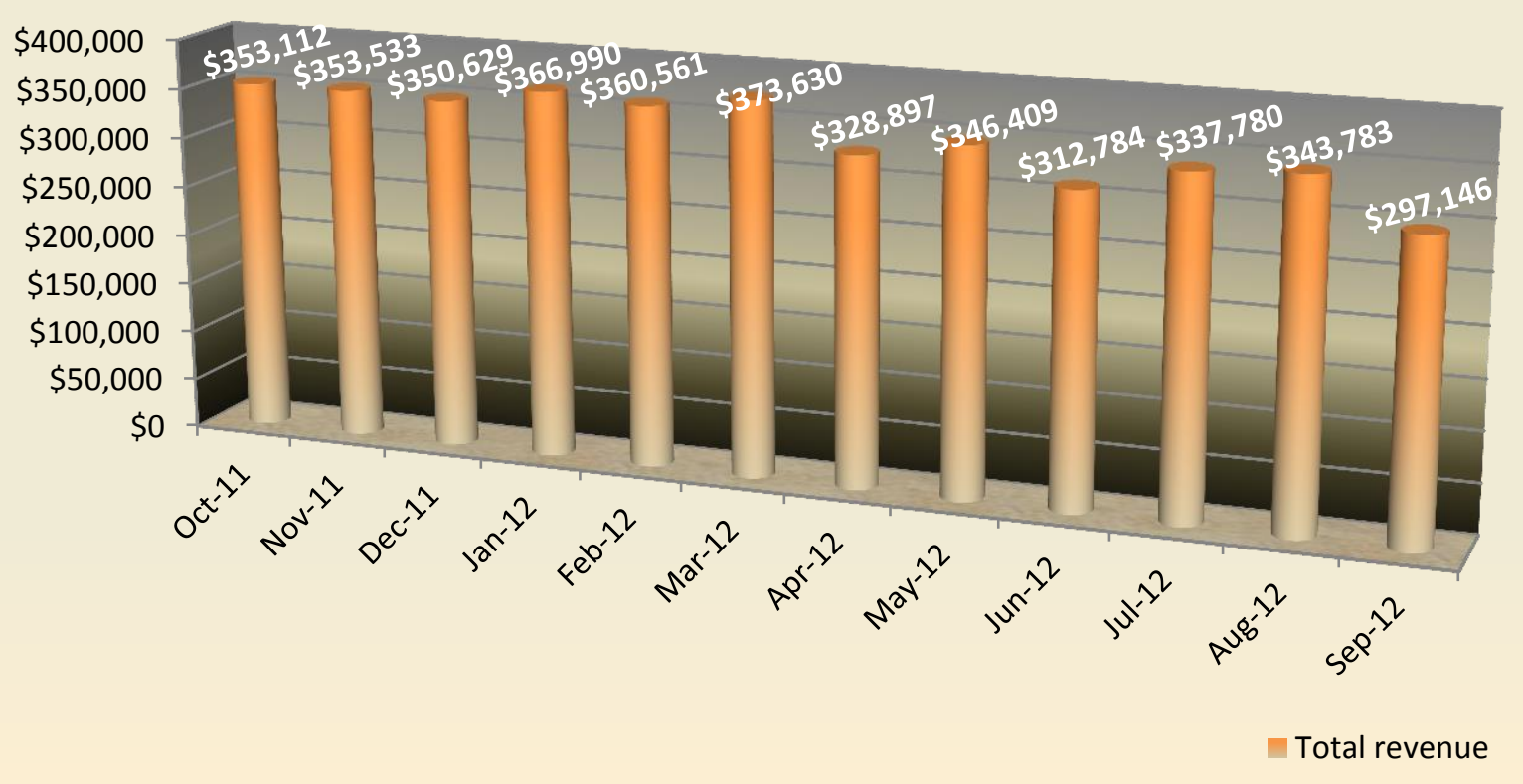

Figure 2-19. TOM Sales Revenue: FY 2012 


\section{Outlet Sales}

Miami-Dade Transit currently has agreements with 86 retail outlets throughout Miami-Dade County to sell EASY Cards and EASY Tickets. The agency promotes the sales outlets on the website by organizing outlets into the following areas of Miami-Dade County:

- Miami Beach

- Downtown

- Central

- Northeast

- Northwest

- Southwest

- Homestead/Florida City

Each retailer is equipped with a point of sale unit (POSU), which is a compact unit capable of

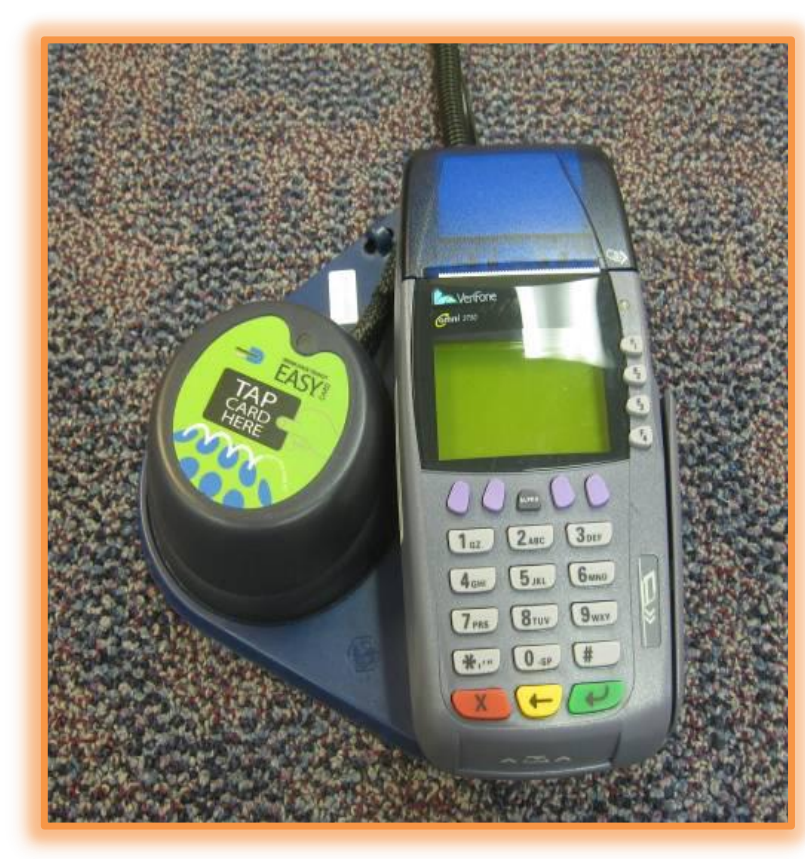

Figure 2-20. Point of Sale Unit selling smart cards as well as adding value. Upon selection of the value to be added, the EASY Card or EASY Ticket is touched to the target on the initialization device. Data is then written to the EASY Card and a record is made of the transaction with sales details for storage. Figure 2-20 displays a point of sale unit.

Miami-Dade Transit supplied aggregate sales data for 2010, 2011 and 2012. Sales data were supplied on a monthly basis. Unfortunately, in 2012, data for the months of August and September were not available. Therefore, in order to show real change over the threeyear period, CUTR used the first ten months (October to July) for each year to equalize the reporting of sales data.

In 2010, total sales were $\$ 10,4$ million with sales peaking in August 2010 with sales of $\$ 1.3$ million (Figure 2-21). By 2011, sales reached a total of $\$ 11.4$ million, with sales peaking in August with $\$ 1.0$ million (Figure $2-22$ ). In 2012 , with only ten months reported, total sales were $\$ 9.8$ million. In the ten months reported for 2012, sales peaked in March 2012 with $\$ 1.1$ million in total sales (Figure 2-23). The raw total of sales for the 34 month period (instead of 36-month period) was $\$ 31.6$ million (Figure 2-24). However, when considering the ten month period for each of 2010, 2011 and 2012, sales in 2010 were $\$ 8.5$ million, in 2011 were $\$ 9.4$ million, and in 2012 were $\$ 9.8$ million. Therefore, 2012 sales of $\$ 9.8$ million 762,700 represent a 18.2-percent increase over 2010 (Figure 2-25). 


\section{RIDERSHIP IMPACTS OF SOUTH FLORIDA'S EASY SMART CARD}

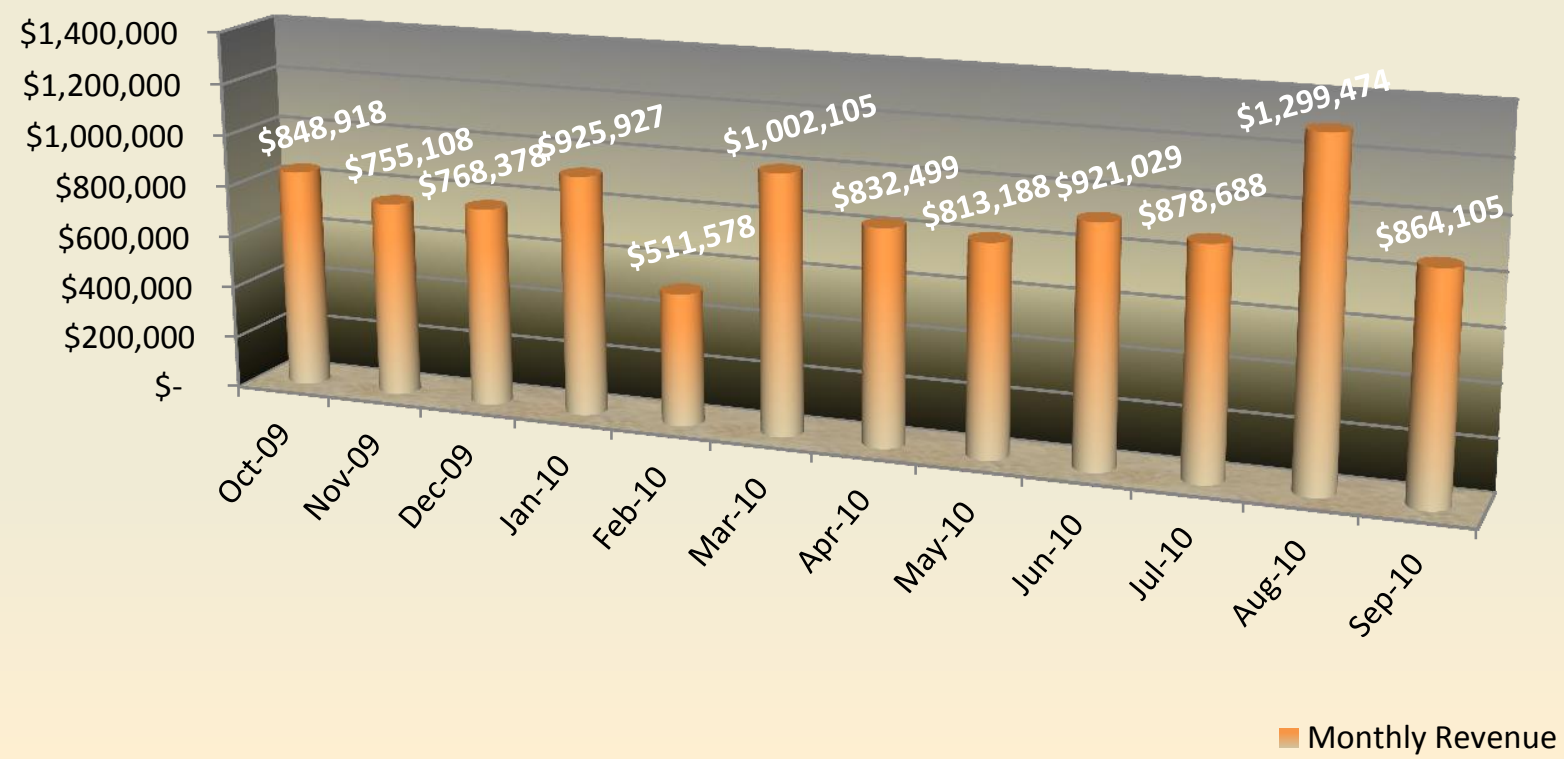

Figure 2-21. Miami-Dade Transit Outlet Revenues: October 2009 - September 2010

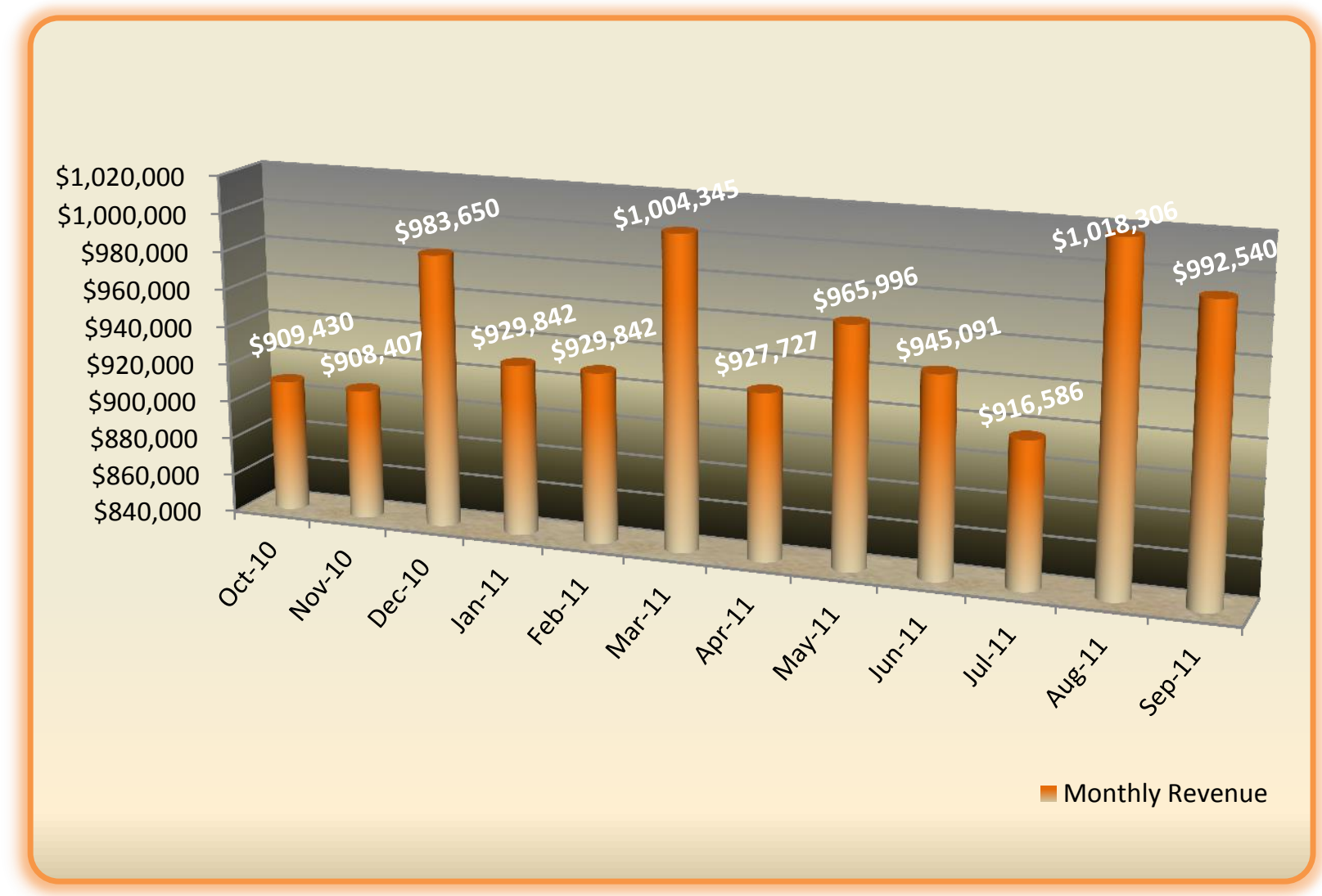

Figure 2-22. Miami-Dade Transit Outlet Revenues: October 2010 - September 2011 


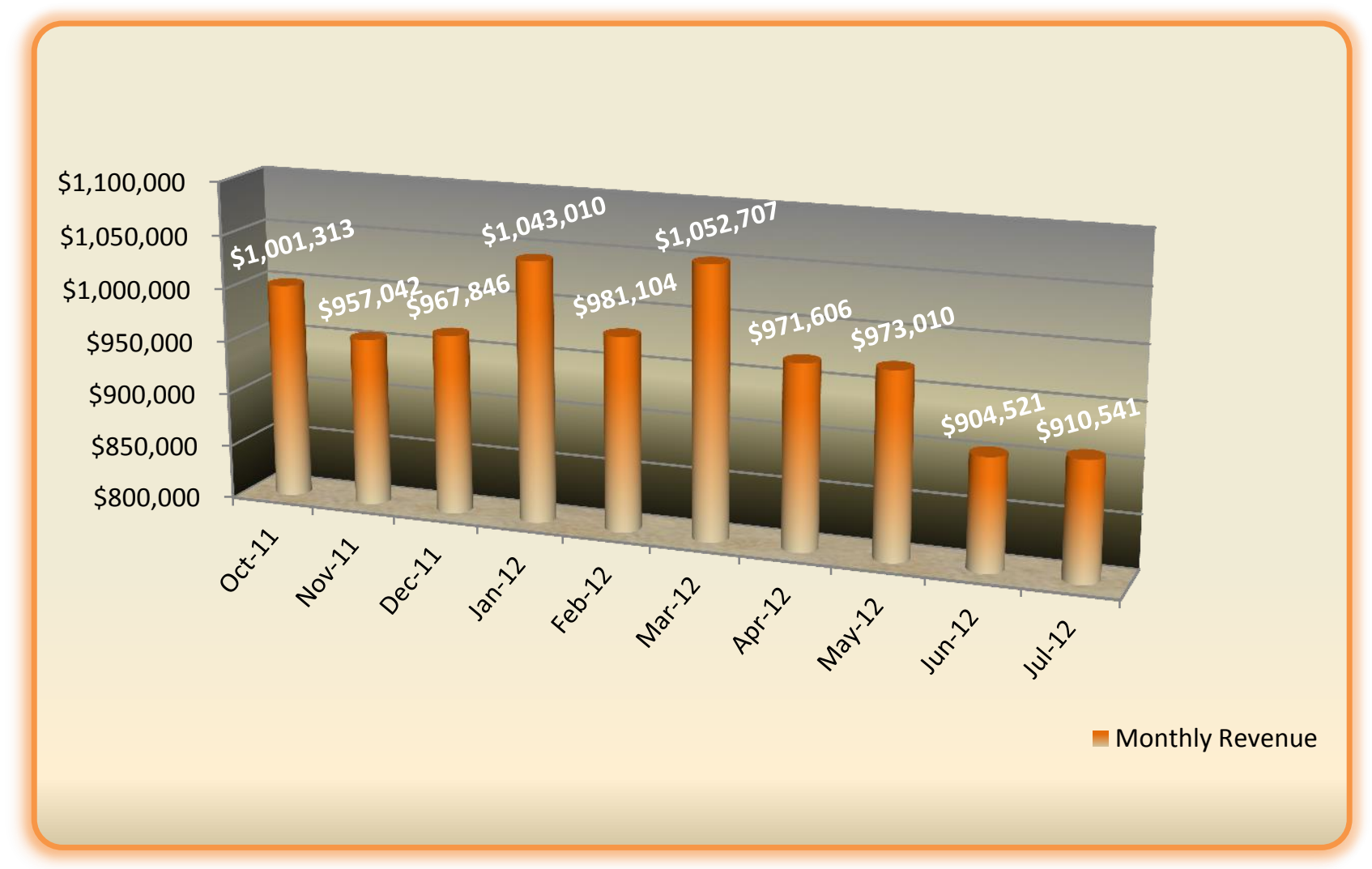

Figure 2-23. Miami-Dade Transit Outlet Revenues: October 2011- July 2012

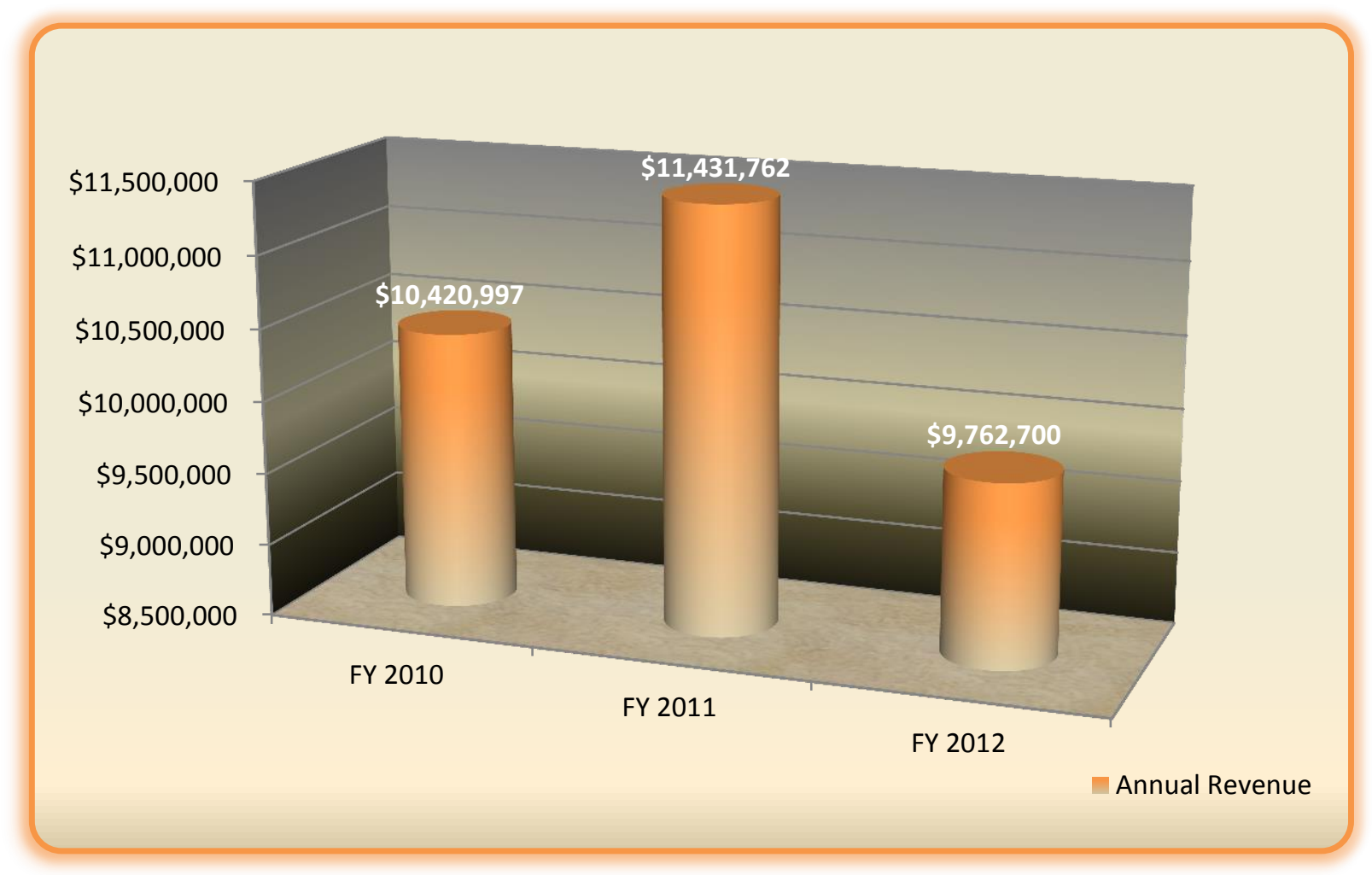

Figure 2-24. Miami-Dade Transit Outlet Revenues: Total Annual Revenue, FY 2010-2012 


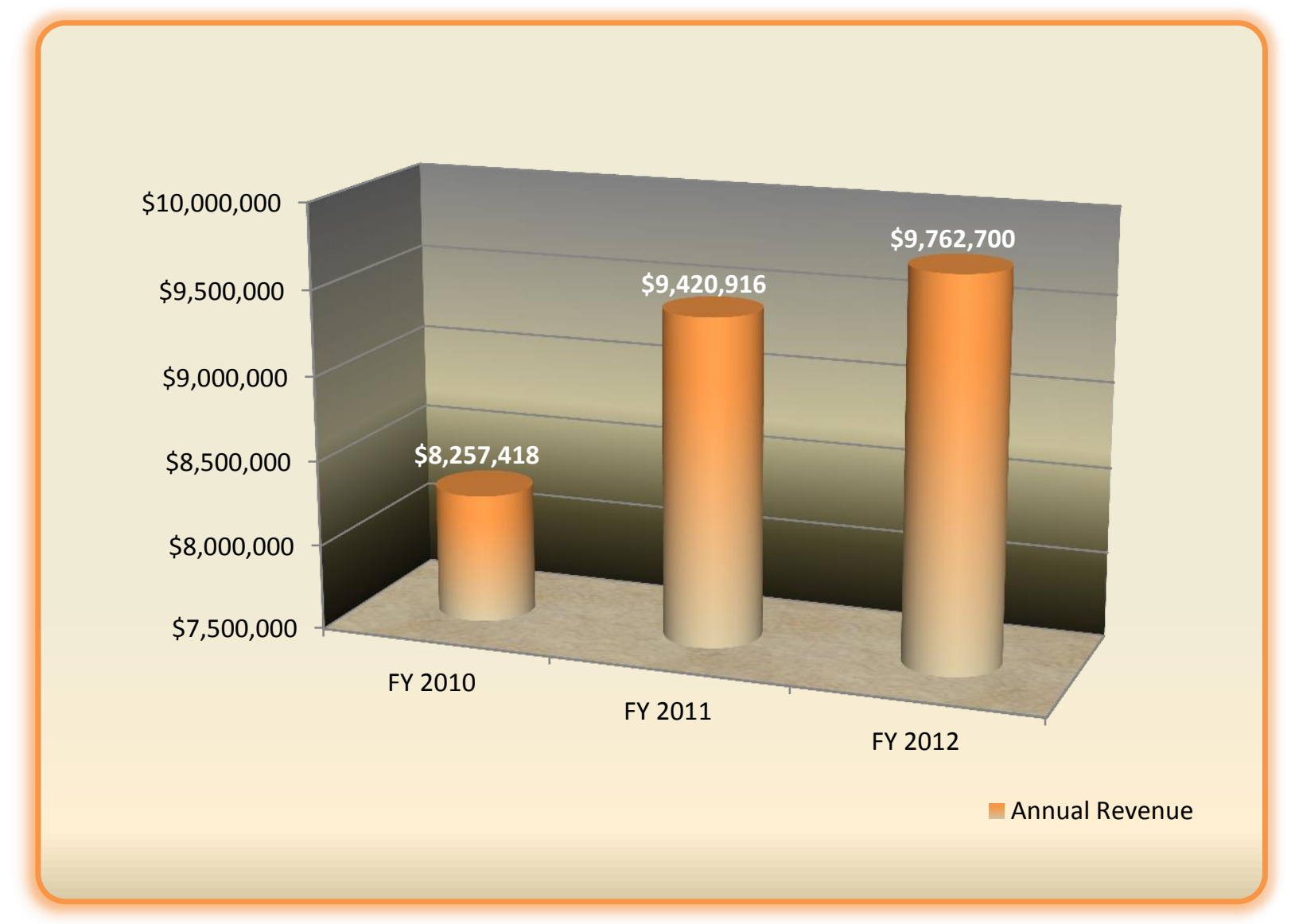

Figure 2-25. Miami-Dade Transit Outlet Revenues: Total Annual Revenue, FY 2010-2012 (Excluding August-September) 


\section{Internet Sales}

One completely new sales outlet created by the AFCS was a web-based program via the internet for EASY Card purchase with credit payment. In some cases, transit agencies have offered pass sales via the internet wherein customers could purchase a pass that was then mailed to their home. With the EASY Card system, customers can purchase initial EASY Cards and EASY Tickets and can also periodically reload via the internet with the following five fare media:

- One-day pass

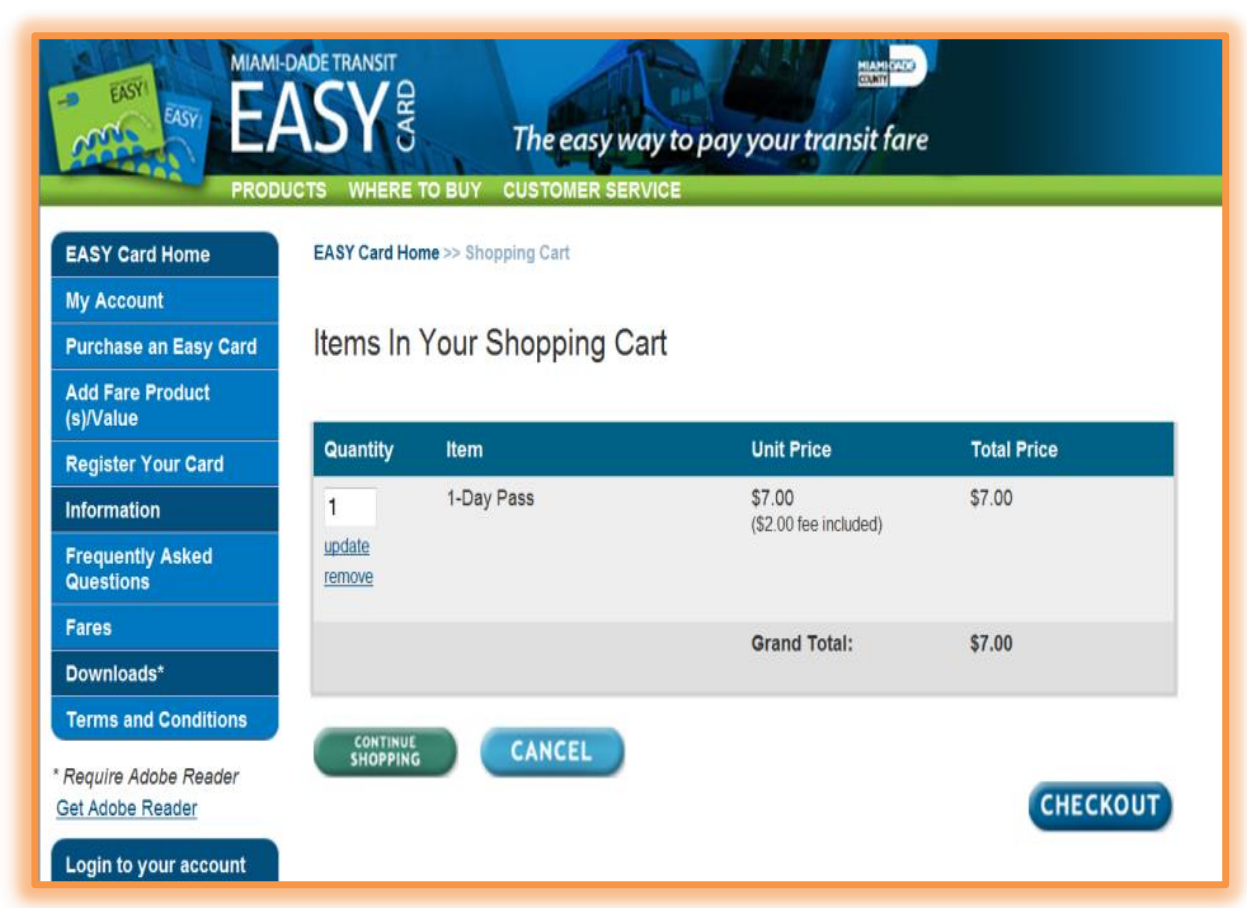

- Seven-day pass

- Monthly Metropass

- Monthly Metropass Plus Parking

- Stored Value with value increments between $\$ 5$ and $\$ 150$

EASY Ticket customers can purchase one of the media above, but EASY Tickets are only good for 60 days and cannot be reloaded via the internet nor phone. Due to the overall limitations of availability (many fare categories are not sold via the internet), internet sales have been modest in relation to all physical sales venues. However, internet sales have increased for the categories of Stored Value, Monthly Metropass and the Seven-day Pass.

Below is data collected from MDT on sales and transactions for each of the five fare categories.

\section{Total Internet Sales}

Total internet sales for the three years from 2010 to 2012 were $\$ 2.39$ million. For the threeyear period, total sales of Stored Value led with $\$ 1.36$ million or 57 percent of all internet sales. Next were Monthly Metropass sales at $\$ 550,100$ or 23 percent of all internet sales. Next were Monthly Pass + Parking at $\$ 182,620$ which was 7.6 percent of all sales. The remaining fare instruments were Seven-day Passes at $\$ 204,984$ (7.5 percent) and One-day Passes at $\$ 57,455$ (2.4 percent).

Stored value had clear year-over-year increases between 2010 and 2012, starting at $\$ 235$, 740 in 2010, increasing to $\$ 467,797$ in 2000 (a 98-percent increase) and then to $\$ 659,123$ 
in 2012 (a 41-percent increase over 2011 and a 180 percent increase over 2010), thus making it the most popular fare media to purchase over the web.

Sales of Monthly Metropasses were mixed, starting at $\$ 172,900$ in 2010 , declining to $\$ 134,300$ in 2011 (a 22-percent decline) and increasing to $\$ 242,900$ in 2012, an overall 40 percent increase over 2010.

The Monthly Pass + Parking also had mixed results starting at $\$ 64,570$ in 2010 and declining to $\$ 56,970$ in 2011 (a 12-percent decline). Then sales in 2012 were $\$ 61,080$ which represented a 5.4 percent decline over 2010 .

Similar to the stored value, the Seven-day Pass also had clear year-over-year increases between 2010 and 2012, starting at $\$ 31,122$ in 2010, increasing to $\$ 72,124$ (a 132-percent increase over 2010), and in 2012 total sales were $\$ 101,738$ (a 41-percent increase over 2011 and a 227 percent increase over 2010.)

Finally, the One-day pass has been a popular fare media to purchase via the internet but generate less revenue starting with sales of $\$ 14,770$ in $2010, \$ 24,495$ in 2011 and $\$ 18,190$ in 2012. One note is that reloading an EASY Card is not immediate and can take up to two days for the reload value to be available for use.

Figure 2-27 displays the total sales by year for each fare type.

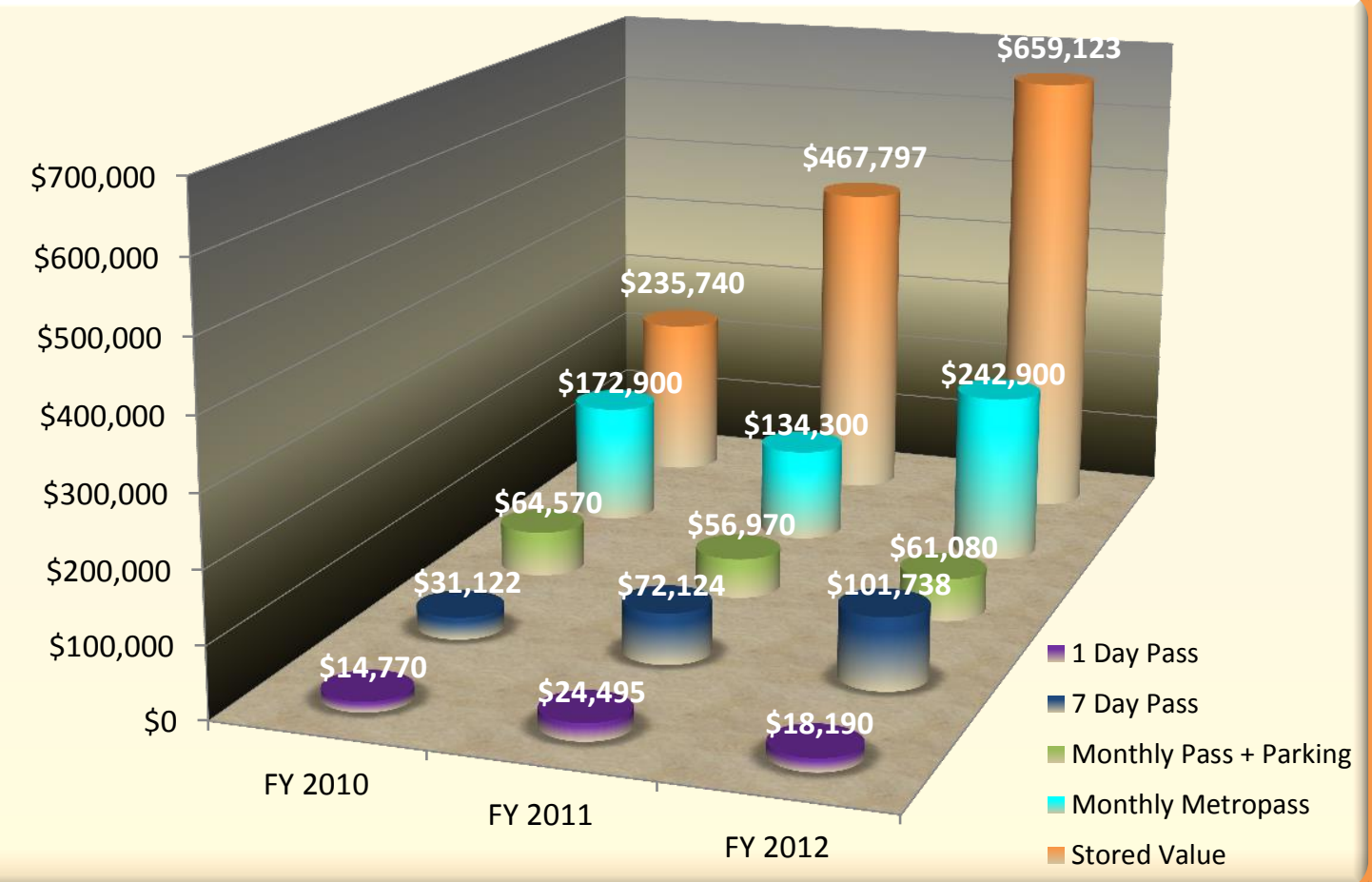

Figure 2-27. Web Sales: All Types, Total Revenue (FY 2010-2012) 


\section{Total Internet Transactions}

For the three-year period from 2010 to 2012, there were 104,582 total transactions via the internet. Of those, there were 77,995 Stored Value transactions representing 74.6-percent of all transactions. One-day passes were next with 11,491 transactions representing 11 percent of all transactions. There were 7,884 Seven-day Pass transactions representing 7.5percent of all transactions. Monthly Metropass had 5,512 transactions which represented 5.2-percent of all transactions and Monthly Pass + Parking had 1,700 transactions representing 1.6-percent.

Stored Value transactions had annual increases starting at 14,060 in 2010, increasing to 28,366 in 2011 (a 102-percent increase over 2010), and 35,569 in 2012 (a 25-percent increase over 2011 and a 153-percent increase over 2010).

Similarily, transactions for Seven-day Passes also had year-over-year increases starting at 1,197 in 2010, increasing to 2,774 in 2011 (a 131-percent increase over 2010), and in 2012, 3,913 transactions (a 41-percent increase over 2011 and a 227-percent increase over 2010)

Sales of Monthly Metropasses were mixed starting at 1,740 transactions in 2010, and declining to 1,343 in 2011 (a 23-percent decline over 2010). Then, in 2012, transactions increased to 2,429 (an 81-percent increase over 2011 and a 40-percent increase over 2010).

One-day Pass transactions were also mixed with 2,954 transactions in 2010, increasing to 4,899 in 2011 (a 66-percent increase over 2010) and declining to 3,638 in 2012 (a 26percent decline over 2011).

Finally, Monthly Pass + Parking also had mixed sales with 619 transactions in 2010, declining to 522 in 2011; and then increasing slightly to 559 transactions in 2012.

Figure 2-28 below displays sales transactions via the internet. 


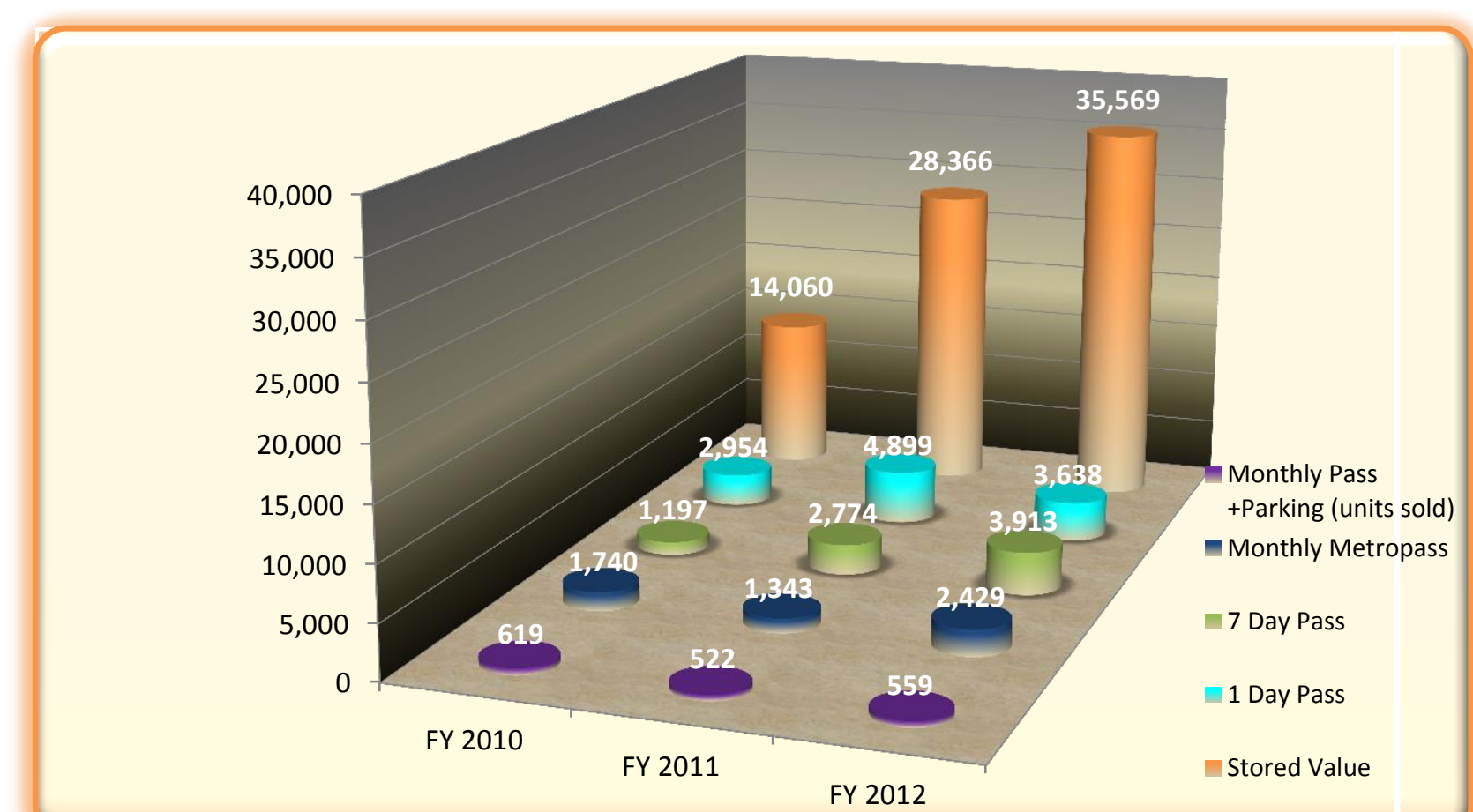

Figure 2-28. Web Sales: All Types, Total Number of Products Sold (FY 2010-2012)

\section{Corporate Discount Program}

Miami-Dade Transit's corporate discount program (CDP) allows participants to save on commuting costs through group discounts and pre-tax savings by obtaining monthly public transportation benefits through a pre-tax payroll deduction from their employer under IRS Code 132(f). The CDP provides 1-Month transit passes on EASY Cards, good for a month of unlimited rides on Metrobus and Metrorail. The EASY Card is automatically reloaded every month with a 1-Month pass as long as the employee remains enrolled in the program. Participants who take Metrorail can save even more by also purchasing their $\$ 10$ monthly Metrorail parking permit with pre-tax dollars.

The regular price of an MDT monthly pass on an EASY Card is $\$ 100$ per month. But through the Corporate Discount Program, groups of four to 99 employees are eligible to purchase passes for $\$ 90$. Groups of 100 or more pay only $\$ 85$ per monthly pass. The passes are distributed by employers. 
In September 2012, 185 employers were participating in the CDP. There was only a slight increase (up from 179 in 2010) in the number of employer participants. Figure 2-29 below shows participating employers between 2010 and 2012. MDT continues efforts to promote the CDP. Some employers, particularly those with a relatively small number of employees, have indicated a reluctance to participate due to the requirement that employers have a dedicated phone line for card management activities, but have expressed interest in participating when the CDP offers a web-based application.

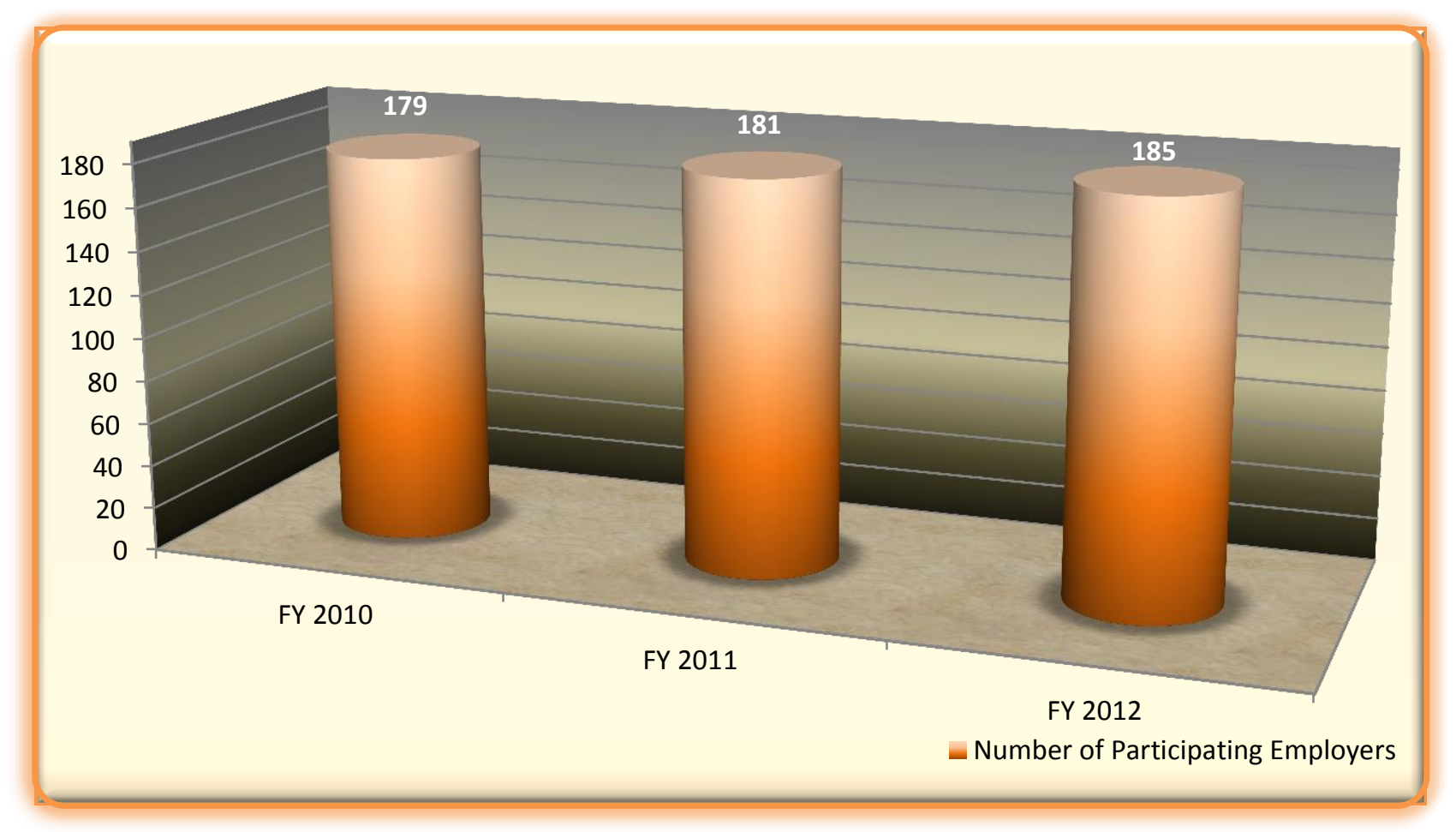

Figure 2-29. MDT Participating Employers: FY 2010-2012 
Figure 2-30 below shows that while the total number of participating employers increased over the three year period, revenue dropped slightly between 2011 and 2012.

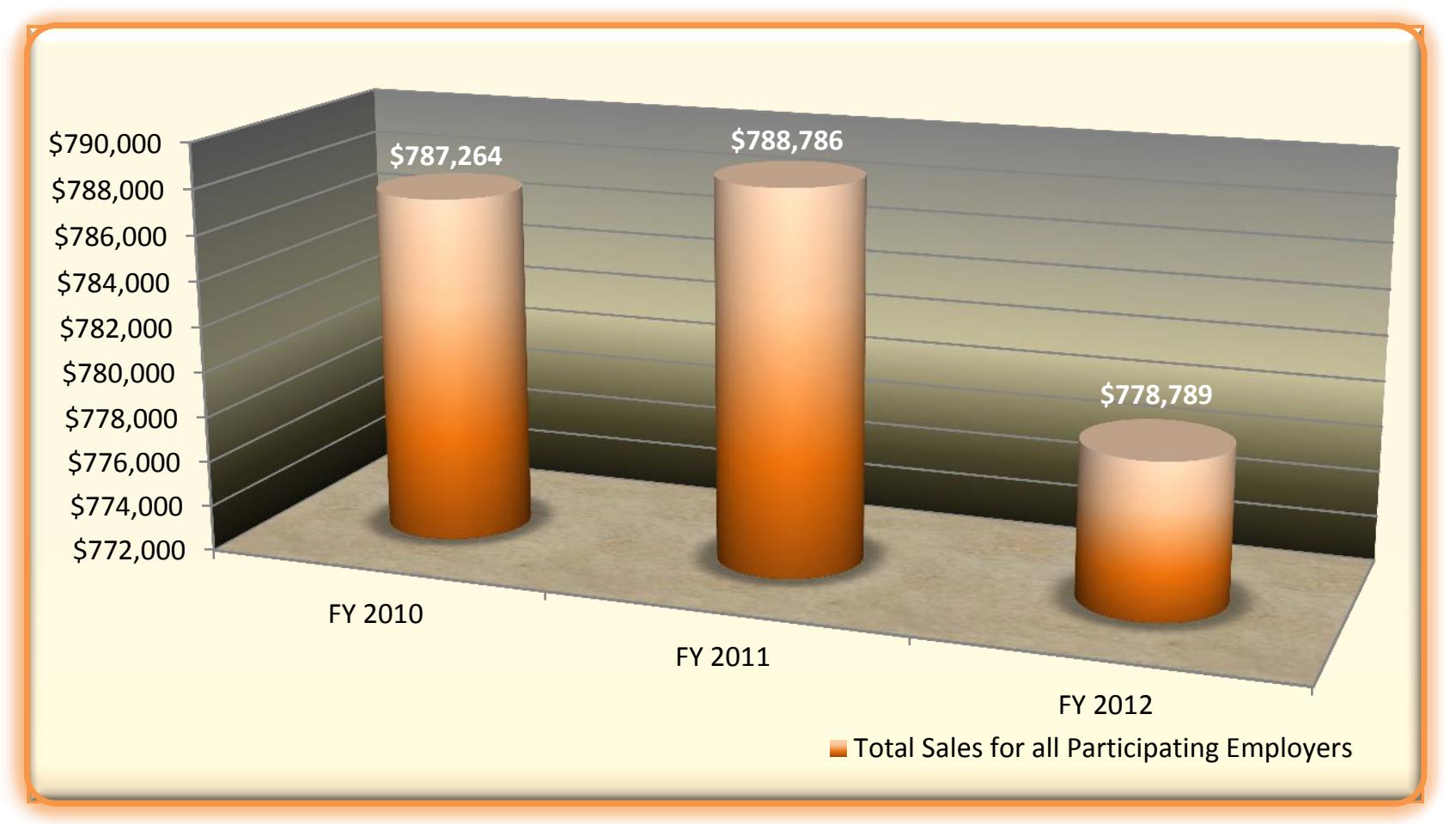

Figure 2-30. Total Sales for all Participating Employers: FY 2010-2012

Tri-Rail also offers an Employer Discount Program (EDP). Currently, more than 2,500 companies in the South Florida region participate. Their employees receive a 25-percent discount on monthly and 12-Trip passes. Tri-Rail offers employees of participating South Florida businesses a 25-percent discount on Monthly and 12-Trip passes. Members of the EDP can obtain an EDP-encoded EASY Card from a designated ticket kiosk, and load their EDP passes directly from Tri-Rail's TVMs located at all stations.

\section{Top Selling Employers}

The University of Miami School of Medicine is the top selling CDP participant. From 2010 to 2012 , total sales were $\$ 733,554$, or 31.1-percent of all CDP sales. Sales peaked in 2010 at $\$ 258,300$ but dipped to $\$ 220,260$ by 2012 , or a 14.7 -percent decrease. Figure $2-31$ below displays sales for the University of Miami School of Medicine from 2010 to 2012.

The top 15 employers purchased $\$ 1.7$ million in EASY Cards over the three-year period, which was 71.1 percent of total sales of $\$ 2.5$ million (see Figure 2-32). 


\section{RIDERSHIP IMPACTS OF SOUTH FLORIDA'S EASY SMART CARD}

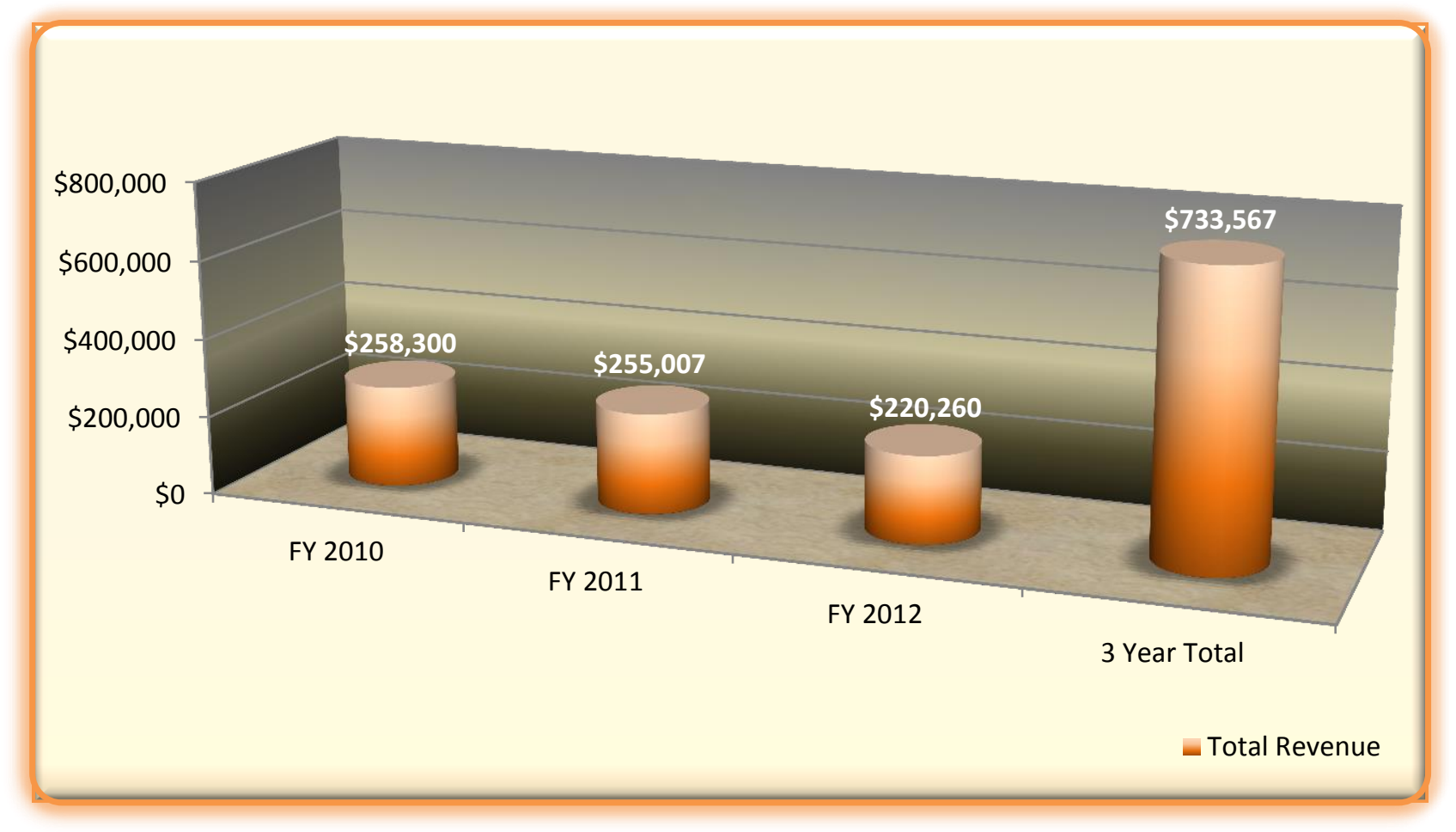

Figure 2-31. University of Miami School of Medicine: CDP Sales - FY 2010-2012

Remaining top sellers, including the University of Miami School of Medicine, are shown in Figure 2-32 below. These corporate partners include Miami-Dade County (payroll deduction), Jackson Memorial Hospital, Baptist Health South Florida, Publix and Wage Works. 


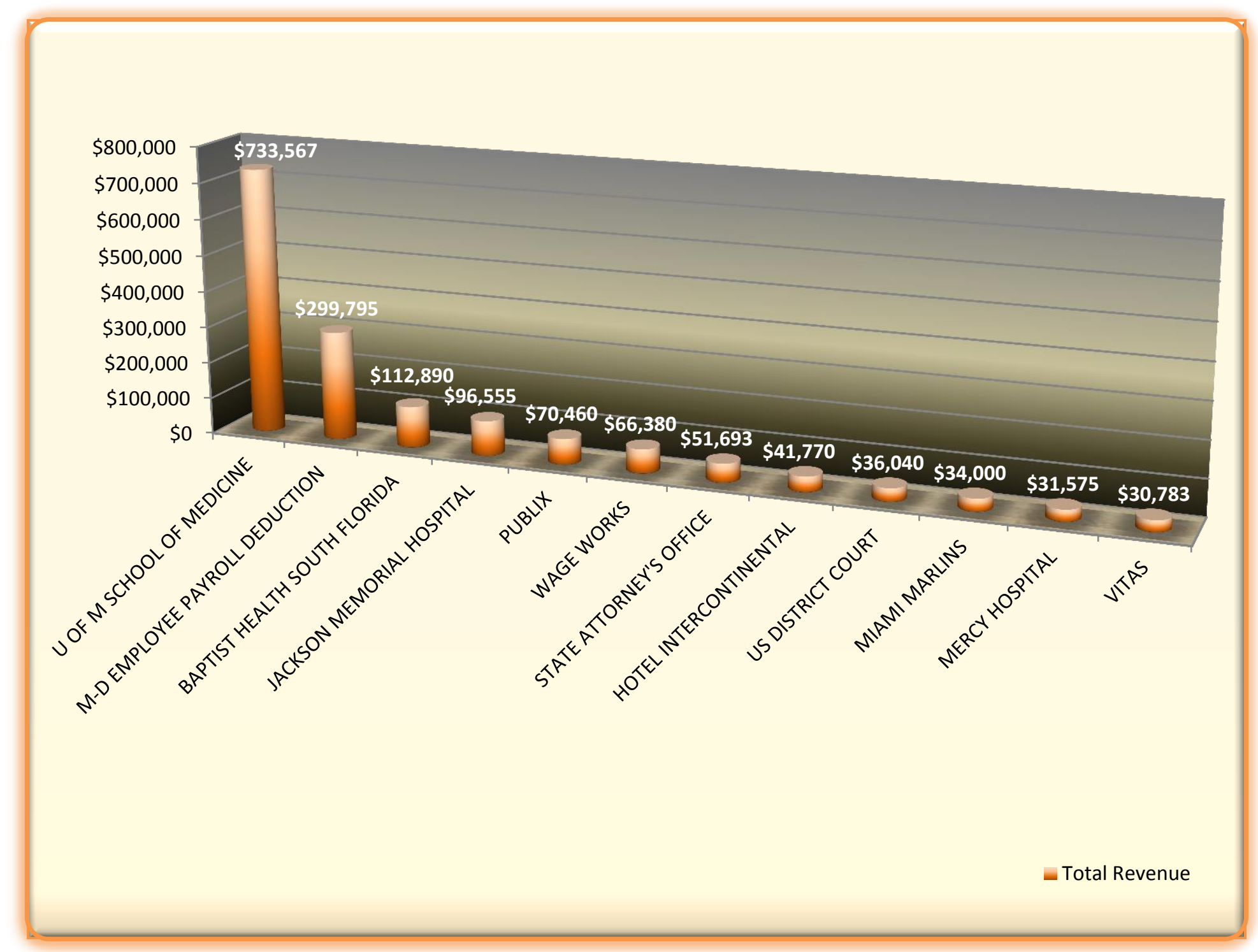

Figure 2-32. Total CDP Sales: FY 2010-2012 


\section{College/University Discount Program}

The College/UniversityDiscount Program (CUDP) allows registered, full-time students at local colleges, universities, and technical and vocational schools to purchase the MDT College EASY Ticket (a 1-Month Pass loaded on an orange EASY Ticket) for just $\$ 50$ - half off the regular $\$ 100$ price. All students enrolled in the CUDP must show a valid Student Identification when using their College EASY Ticket. College EASY Tickets are sold exclusively at participating schools.

As of September 2012, there were 42 educational institutions participating in the program, a 40 percent increase over 2010. Particularly at the larger schools, the availability of discounted EASY Tickets is promoted via the institution's website and in school catalogues.

Florida International University (FIU) and Miami-Dade College (MDC) are examples of institutions that further incentivize students to participate in the CUDP Program by promoting the availability of an Emergency Ride Home Program on dedicated websites: get2FIU and get2MDC transportation services website. FIU and MDC students who ride transit two or more days per week can receive up to six free taxi cab vouchers a year to use in the event of an unexpected emergency or unscheduled overtime when transit service may not be available. According to the MDT website, the CUDP is administered as follows:

- There is no minimum or maximum purchase when placing an order for College Discount Passes.

- All participating schools must place their order and pay for their College Discount Passes after the 20th day of the month for the following month's tickets.

- MDT accepts Visa/MasterCard/AMEX/School checks as a form of payment.

- MDT Finance Division will provide the requested number of College Discount Passes, already pre-coded with the fare media for the requested month.

- Parking permits are not sold separately and must be ordered and paid when placing the College Discount Pass order.

- The schools will sell the pre-coded College Discount Passes and Parking Permits jointly to the students.

- All participating schools are responsible for the verification of student enrollment for the purchase of College Discount Passes. Students must be enrolled full-time in order to purchase a College Discount Pass.

- If supply of College Discount Passes and/or Parking Permits is exhausted, students will need to wait until the following month to obtain the discount. College Discount Passes and Parking Permits are not sold at the discounted rate anywhere but at the school where the student is enrolled. 


\section{Sales at Colleges and Universities}

As the EASY Card program rolled out, there were 30 participating colleges and universities in the program. By 2011, that number had increased 40-percent to 42 participating institutions. Figure 2-33 below shows that the number of participating institutions held steady in 2012 at 42.

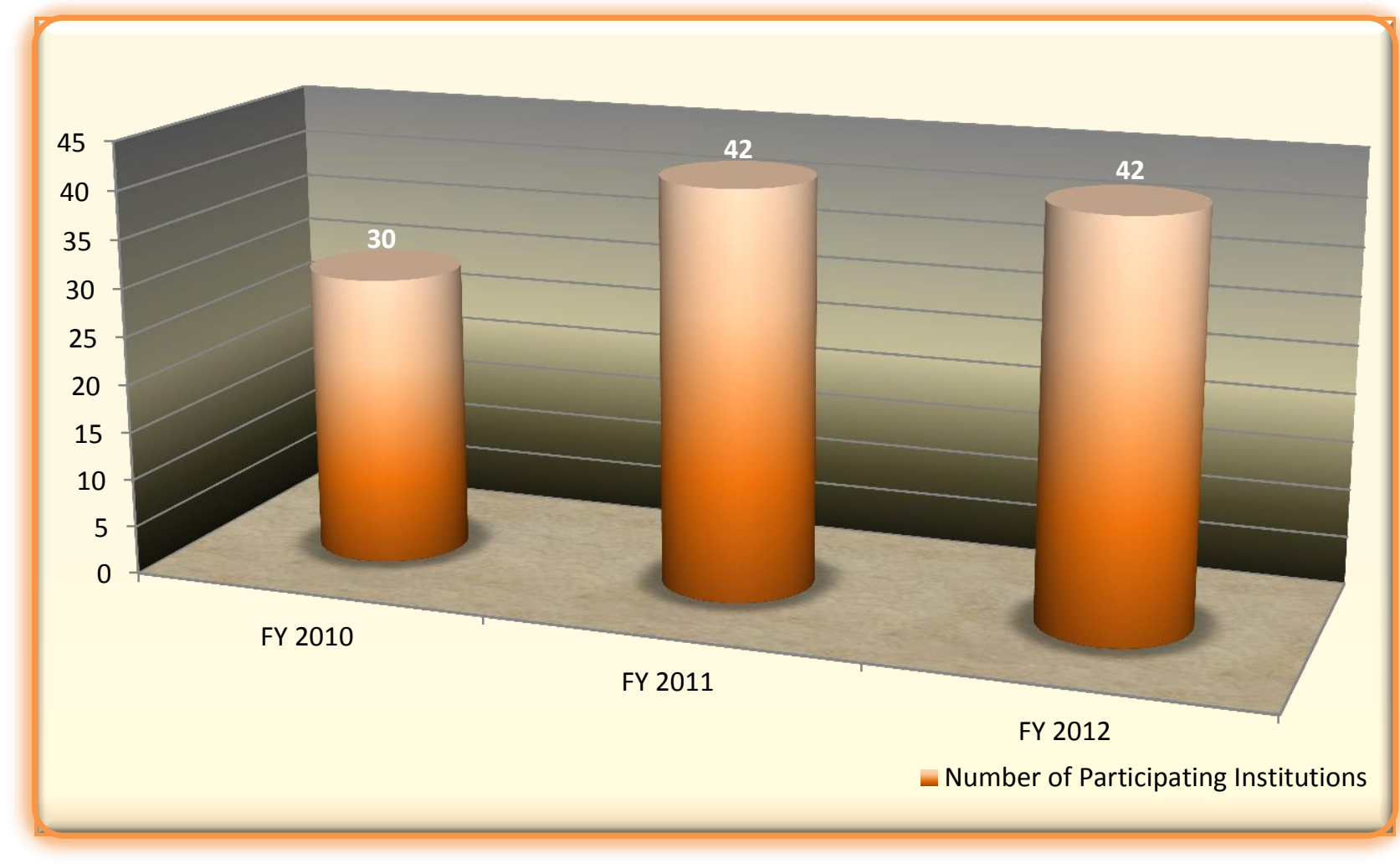

Figure 2-33. Number of Participating Institutions, By Year: FY 2010-2012 
Figure 2-34 shows the growth in total sales increased only slightly from $\$ 375,365$ in 2010 to $\$ 378,000$ in 2011 . However, by 2012 sales rose to $\$ 411,250$, which was an 8.8-percent increase. Total sales for the three-year period were $\$ 1,164,615$, or 23,292 EASY Tickets sold at a price of $\$ 50.00$ each.

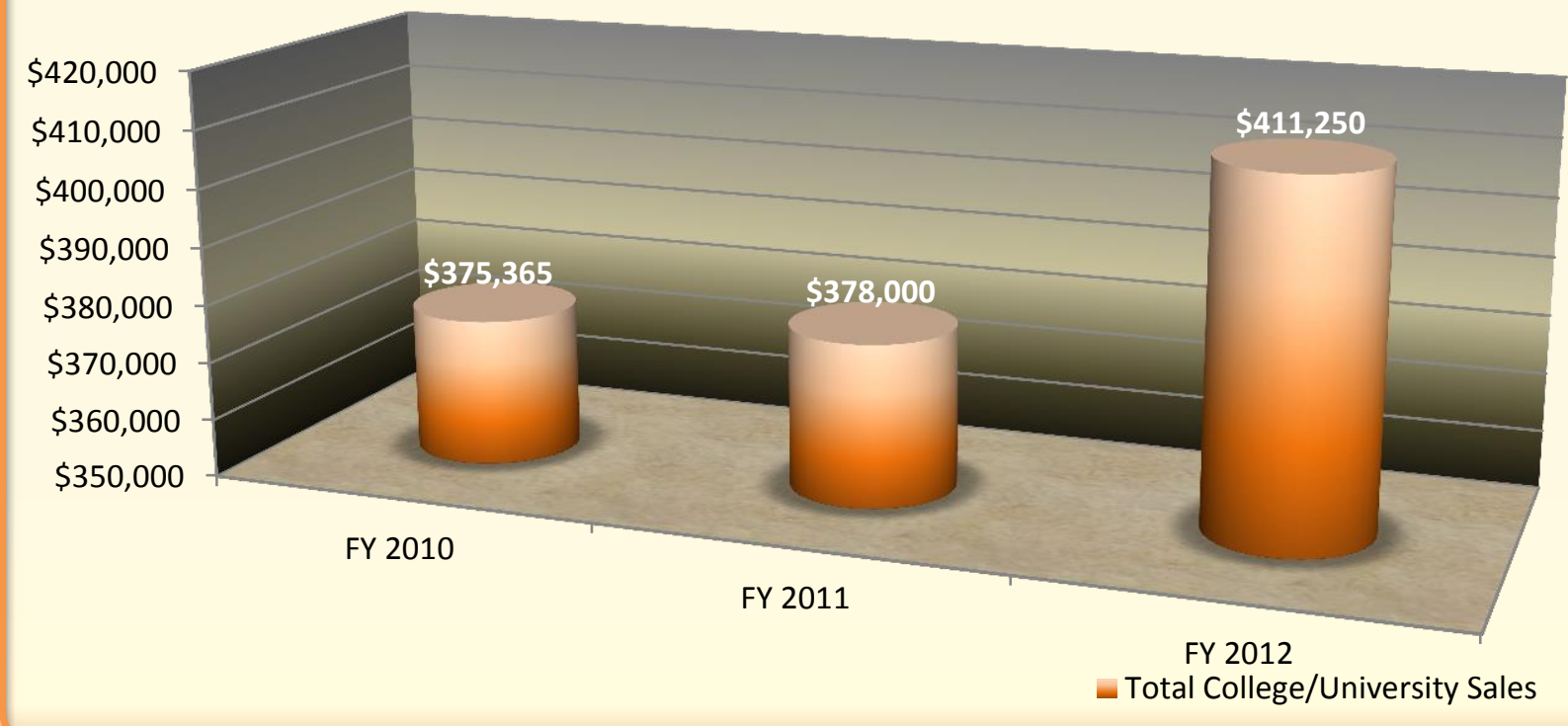

Figure 2-34. Total College/University Sales: FY 2010-2012

Of all participating institutions, Miami-Dade College (MDC) stands out as a primary purchaser of College Discount Program EASY Tickets. From 2010 to 2012, MDC purchased $\$ 807,000$ (approximately 16,140 EASY Tickets at $\$ 50$ each) in EASY Tickets. With sales of $\$ 275,480$ in 2012 increasing six-percent over sales of $\$ 260,380$ in 2010. Figure 2-35 below displays the total three-year sales for MDC. Of the remaining universities, top sellers include Florida International University, the University of Miami Coral Gables, and the University of Miami Medical School (Figure 2-36). Remaining institutions depicted in Figure 2-37 all purchased less than $\$ 10,000$ in total EASY Tickets.

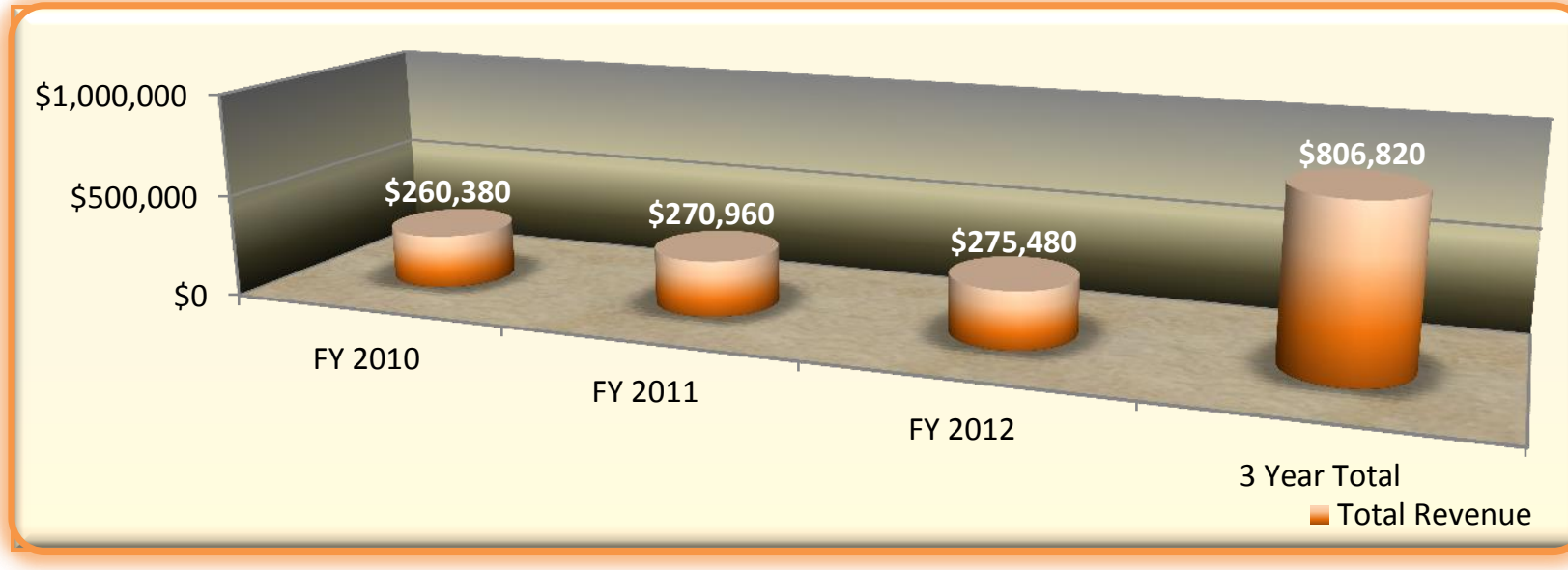

Figure 2-35. Miami-Dade College: College Pass Sales, FY 2010-2012 


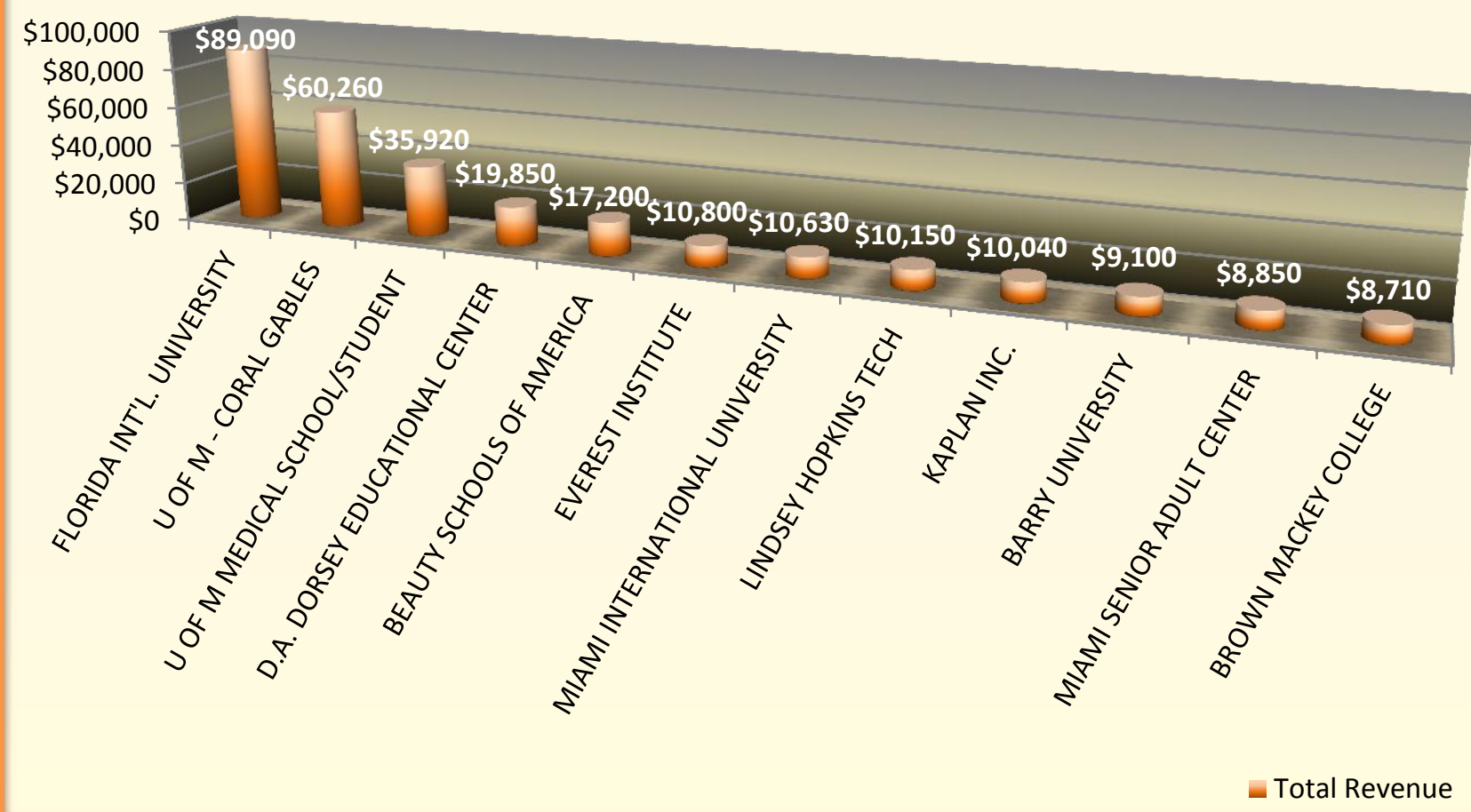

Figure 2-36. Total College Pass Sales: Top Sellers, FY 2010-2012 


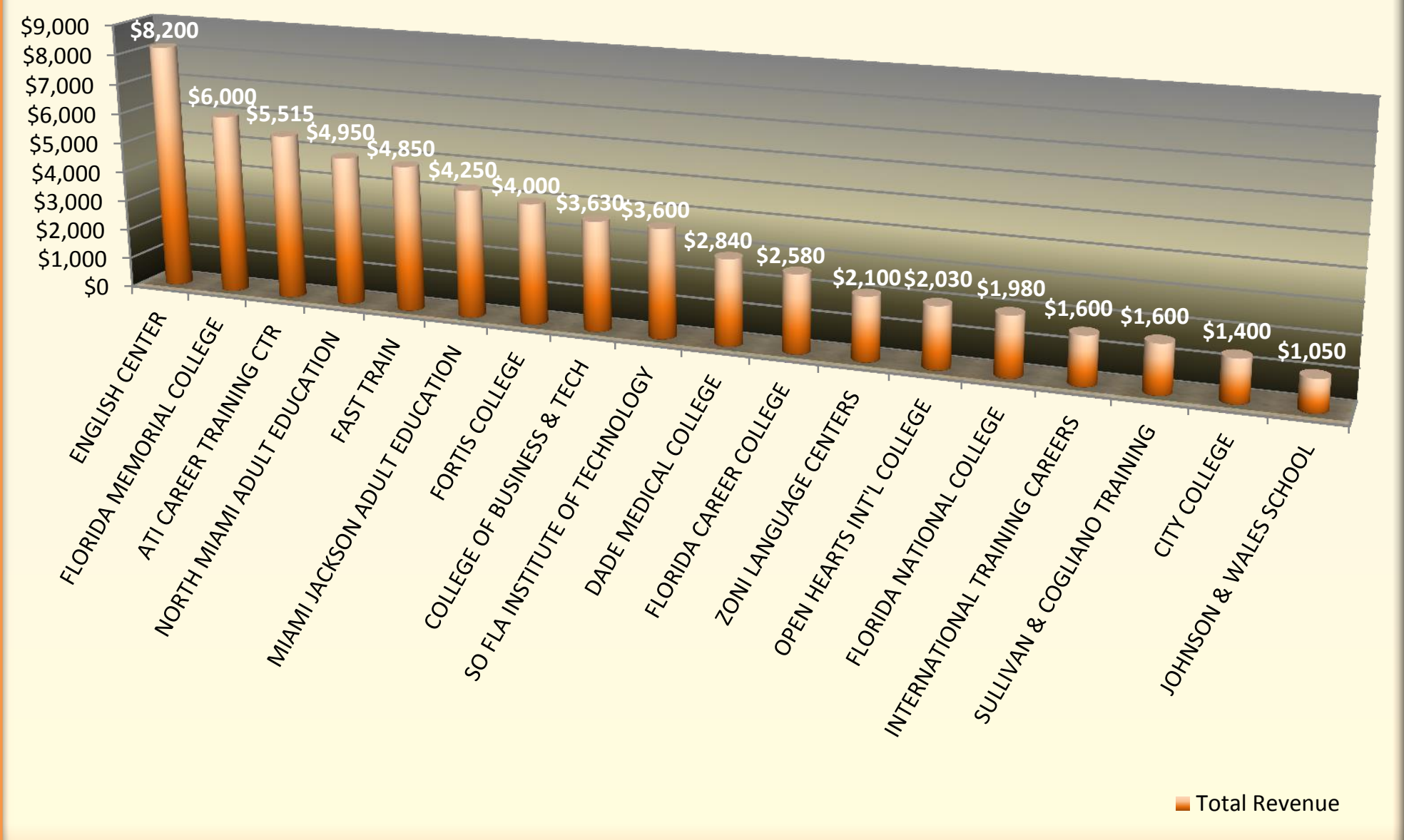

Figure 2-37. Total College Pass Sales: Remaining Sales, FY 2010-2012 


\section{Revenue Impacts}

For all of the sales venues and programs, the cumulative sales for the three-year period were $\$ 135.5$ million. TVM sales were 63-percent of total sales and outlet sales were 23 percent of sales totals. Figure 2-38 below displays cumulative sales for all venues and programs analyzed as part of this study.

$\$ 90,000,000$

$\$ 85,000,000$

$\$ 80,000,000$

$\$ 75,000,000$

$\$ 70,000,000$

$\$ 65,000,000$

$\$ 60,000,000$

$\$ 55,000,000$

$\$ 50,000,000$

$\$ 45,000,000$

$\$ 40,000,000$

$\$ 35,000,000$

$\$ 30,000,000$

$\$ 25,000,000$

$\$ 20,000,000$

$\$ 15,000,000$

$\$ 10,000,000$

$\$ 5,000,000$

$\$ 0$

\section{$\$ 84,820,231$}

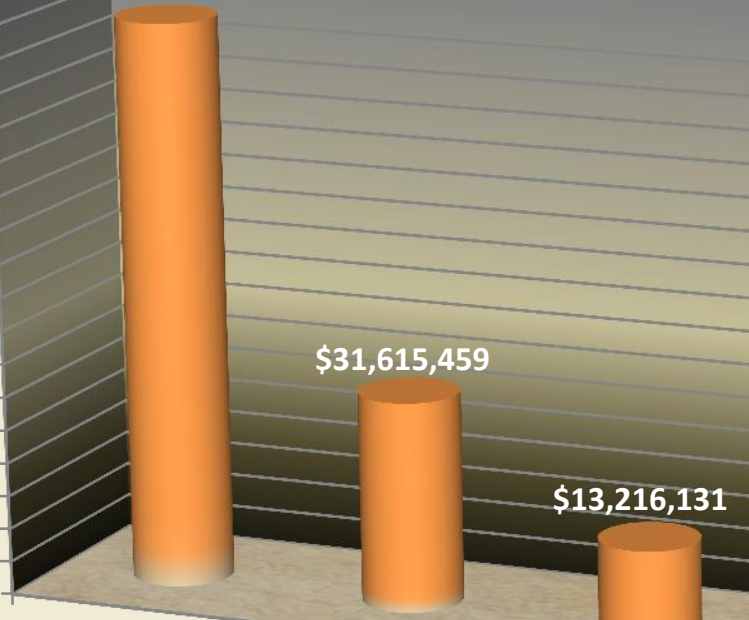

Ticket Vending Machines

Outlet Sales

Ticket Office Machines Internet Sales
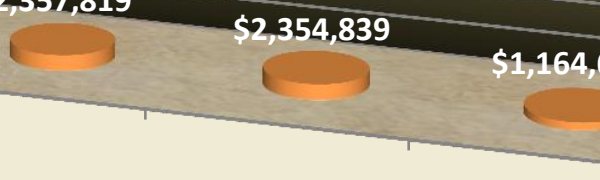

$\begin{array}{cc}\text { Corporate } & \text { Colleges and } \\ \text { Discount } & \begin{array}{c}\text { Universities } \\ \text { Sales }\end{array}\end{array}$

Figure 2-38. Total Cumulative Sales - All Outlets and Programs, FY 2010- 2012 
This page intentionally left blank 


\section{Chapter 3}

\section{Ridership Impacts}

\section{Ridership Impacts - Metrorail}

The primary impact of the implementaton of EASY Card and EASY Ticket for Metrorail customers was that all other fare media were eliminated. Customers are required to have an EASY Card or Ticket in order to use the Metrorail system. MDT supplied overall rail ridership and ridership by fare category for the three-year period 2010-2012. CUTR then examined the highest ridership generated by the top 24 fare categories. In 2010, the top 24 categories accounted for 97-percent, in 2011, 95-percent, and in 2012, 98-percent of all Metrorail passenger trips

\section{Total Metrorail Passengers, FY 2010-2012}

In 2010, total ridership on Metrorail was 17,351,553. By 2011, ridership increased by 763,230 passenger trips to $18,134,783$, which was a 4.39 -percent increase over 2010 . In 2012 , ridership increased by 542,937 passenger trips to $18,667,720$, which was a 2.99 percent increase over 2011. Figure 3-1 below shows growth in overall ridership from 20102012.

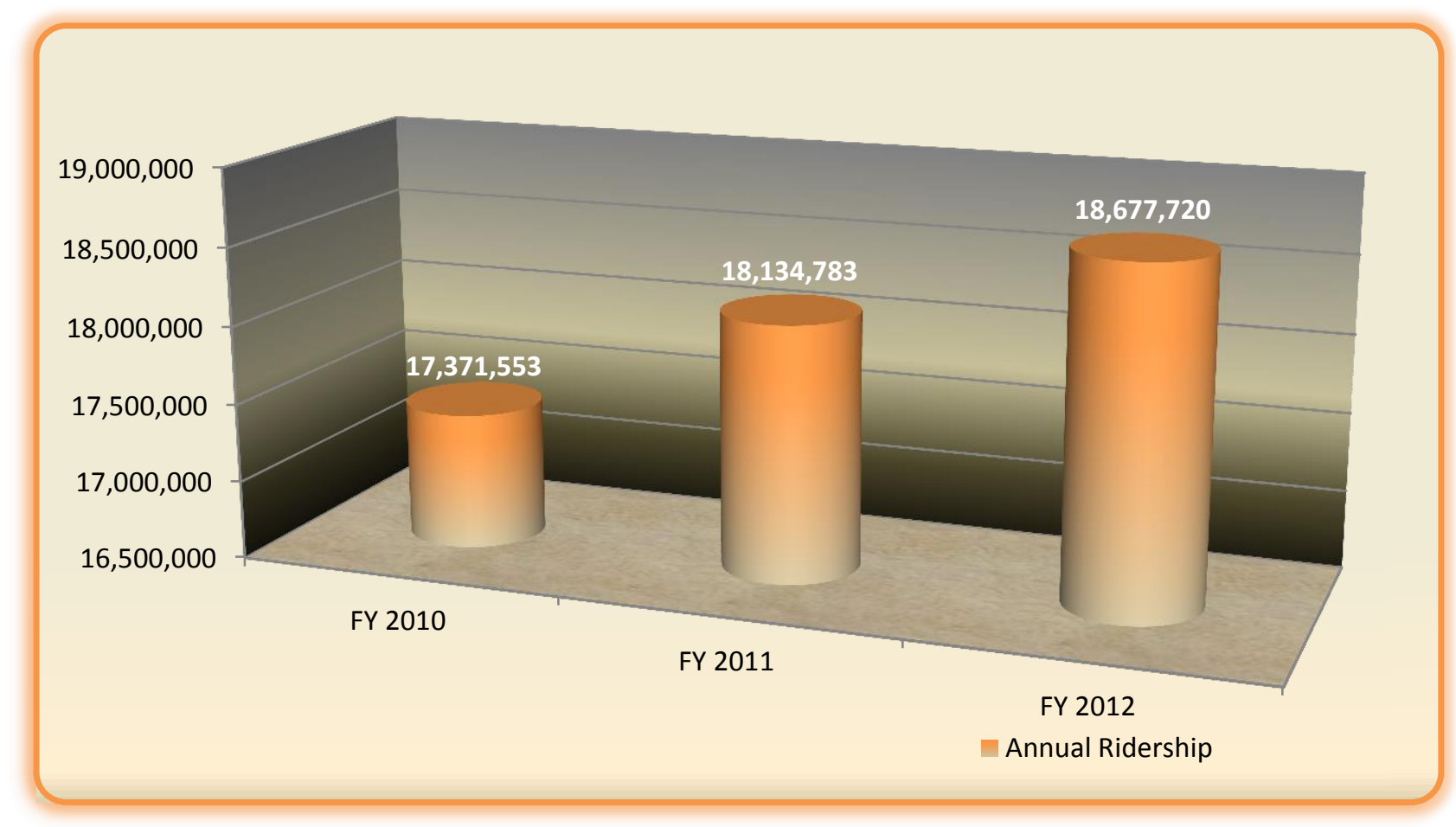

Figure 3-1. Total Metrorail Passengers, FY 2010-2012 


\section{Ridership by Fare Category}

As mentioned above, ridership for the top 24 fare categories accounted for 97-percent of all passenger trips in 2010. The top 12 fare categories ranged from 568,000 to 2,600,000 passenger trips and the second tier 12 categories ranged from 87,000 to 525,000 passenger trips.

Stored Value Full Fare was the number one fare category at 2,613,240, which was 15percent of all Metrorail passenger trips. The 7 Day Corporate Pass, which was available under the Corporate Discount Program in the first year of implementation, accounted for 1.7 million trips. In 2011, this changed to Pre-paid Benefit (PPB) Monthly. Stored Value Limited Use (LU), 1 Day Ticket, and Monthly Ticket are all EASY Tickets. Stored Value Elderly, from consultations with MDT staff, is the same as a Golden Passport. This means that the fare category says, "Stored Value," but fares for seniors are actually free. Stored Value Elderly accounted for 1.2 million passenger trips in 2010. Other top fare categories include Federal Monthly Ticket (EASY Ticket), Monthly Metropass, Transfers, Stored Value Corporate PPB (later changed to Monthly PPB), and Monthly Pass + Parking.

In the 12 second tier ridership by fare category in 2010, the Seven-day Pass and the Oneday Pass each had more than 500,000 passenger trips. The fare category Stored Value Station Service is an administrative fare category for the MDT organization. Annual Patriot Pass, which is also free fare, appears in this group with 332,000 passenger trips. Also, SFRTA Monthly Corporate Discount and SFRTA 1 day tickets appear in this grouping. Figures 3-2 and 3-3 display the ridership by fare category for the top 12 and the next 12 fare categories in 2010. 


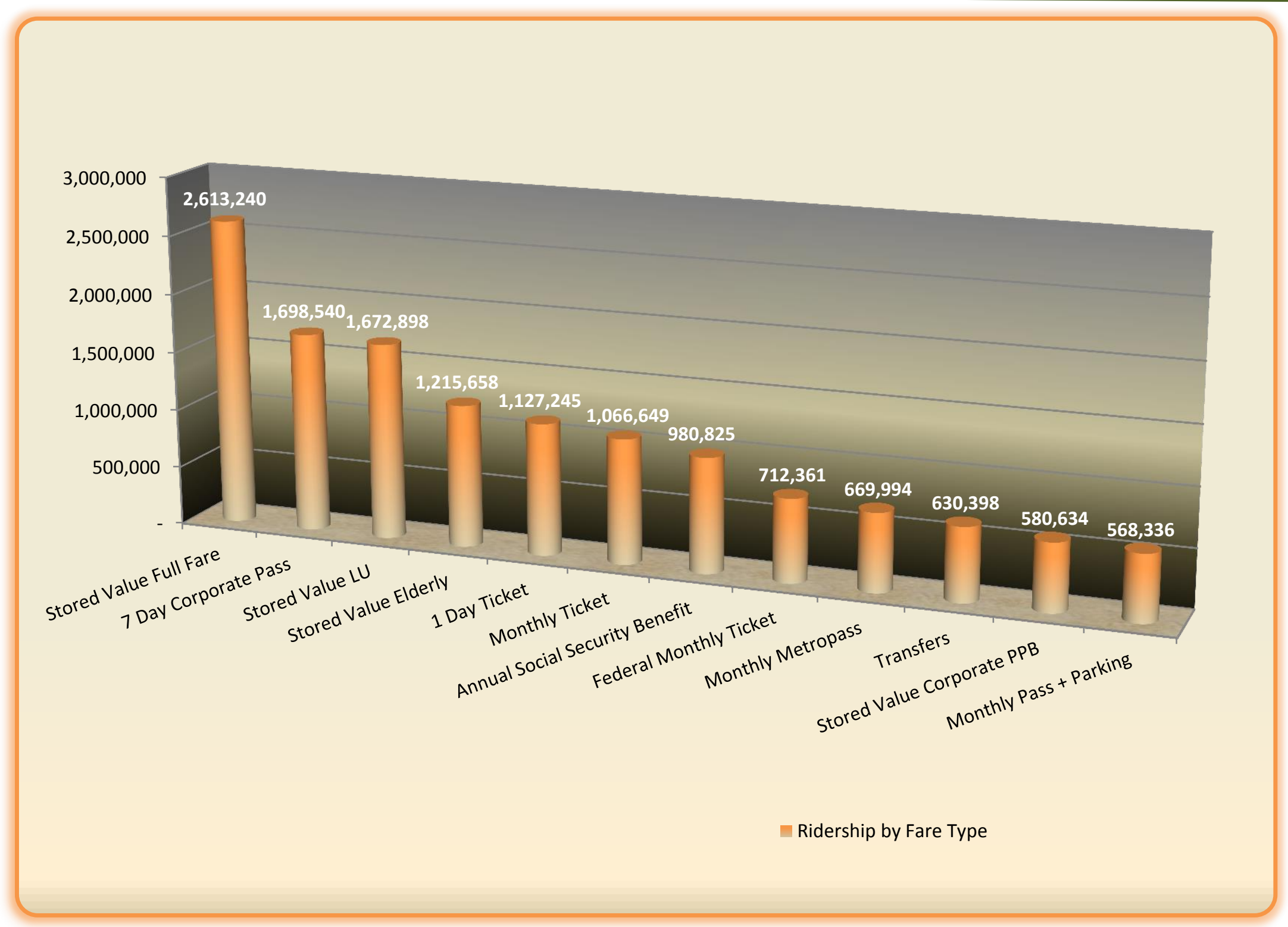

Figure 3-2. Ridership by Most Utilized Fare Categories: EASY Card and EASY Ticket (October 2009 - September 2010) 


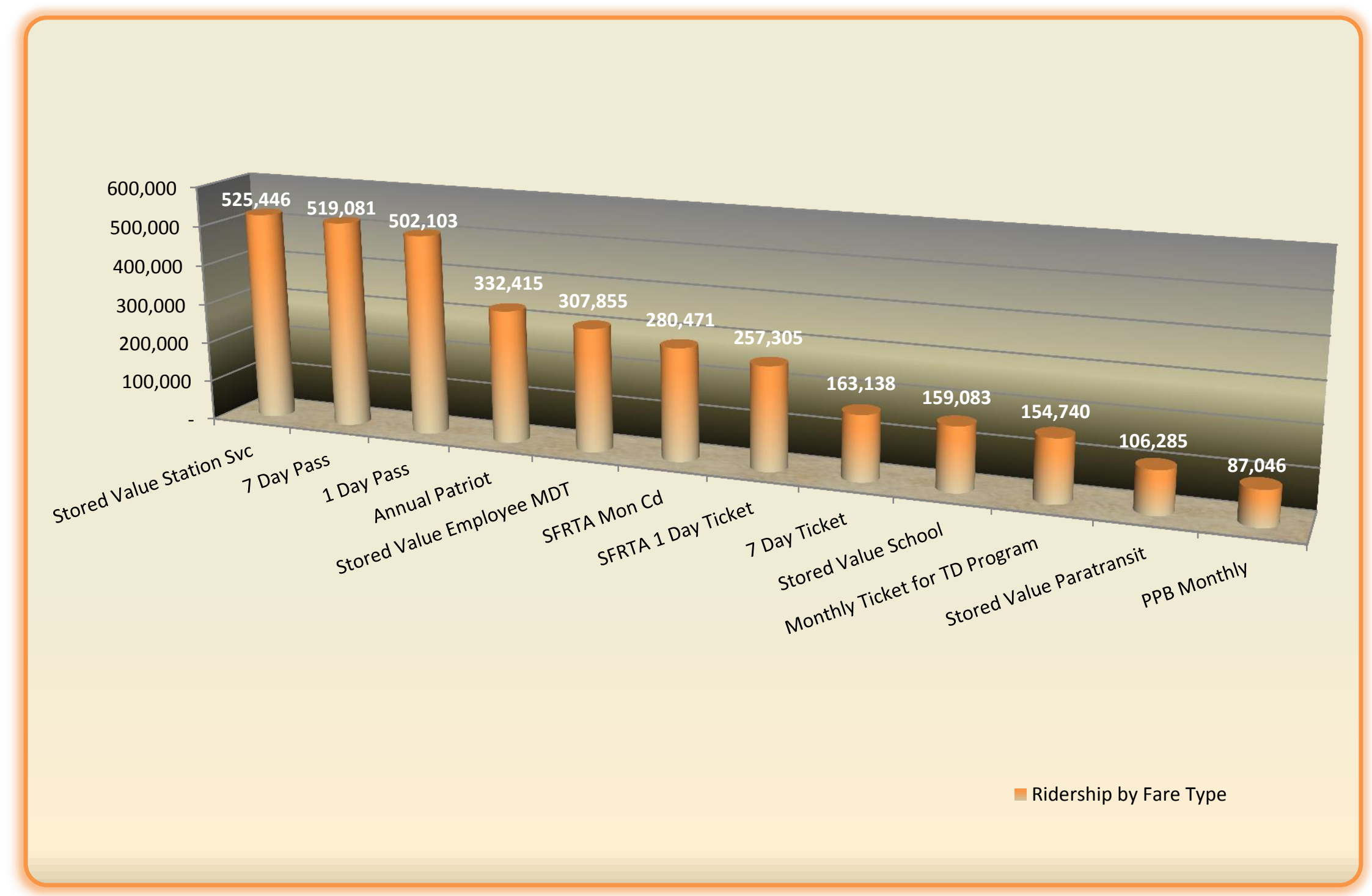

Figure 3-3. Ridership by Next Most Utilized Fare Categories - EASY Card and EASY Ticket (October 2009 - September 2010) 
The top 12 ridership by fare categories range from 579,000 to 2,252,000 annual passenger trips. Ridership for the top 24 fare categories in 2011 accounted for 95-percent of all passenger trips. In 2011, Stored Value Full Fare was once again the top category with 2,252,750 passenger trips, but decreased to 12.42-percent of all passenger trips compared to 15-percent in 2010. The One-day Ticket, which is an EASY Ticket moved into the second spot with Monthly PPB in the third spot with 1.56 million passenger trips (Corporate Discount Program). Stored Value Elderly (Golden Passport, free fare) generated 1.2 million passenger trips. Stored Value LU, 1 Day ticket, Monthly Ticket and Federal Monthly Ticket are all EASY Ticket fare categories.

The second tier of ridership by fare category, ranged from 128,000 to 478,000 annual passenger trips. The one day ticket was used for 477,825 passenger trips followed by Stored Value Employee MDT at 439,384 passenger trips. Figures 3-4 and 3-5 display the top 24 ridership by fare category for 2011. 


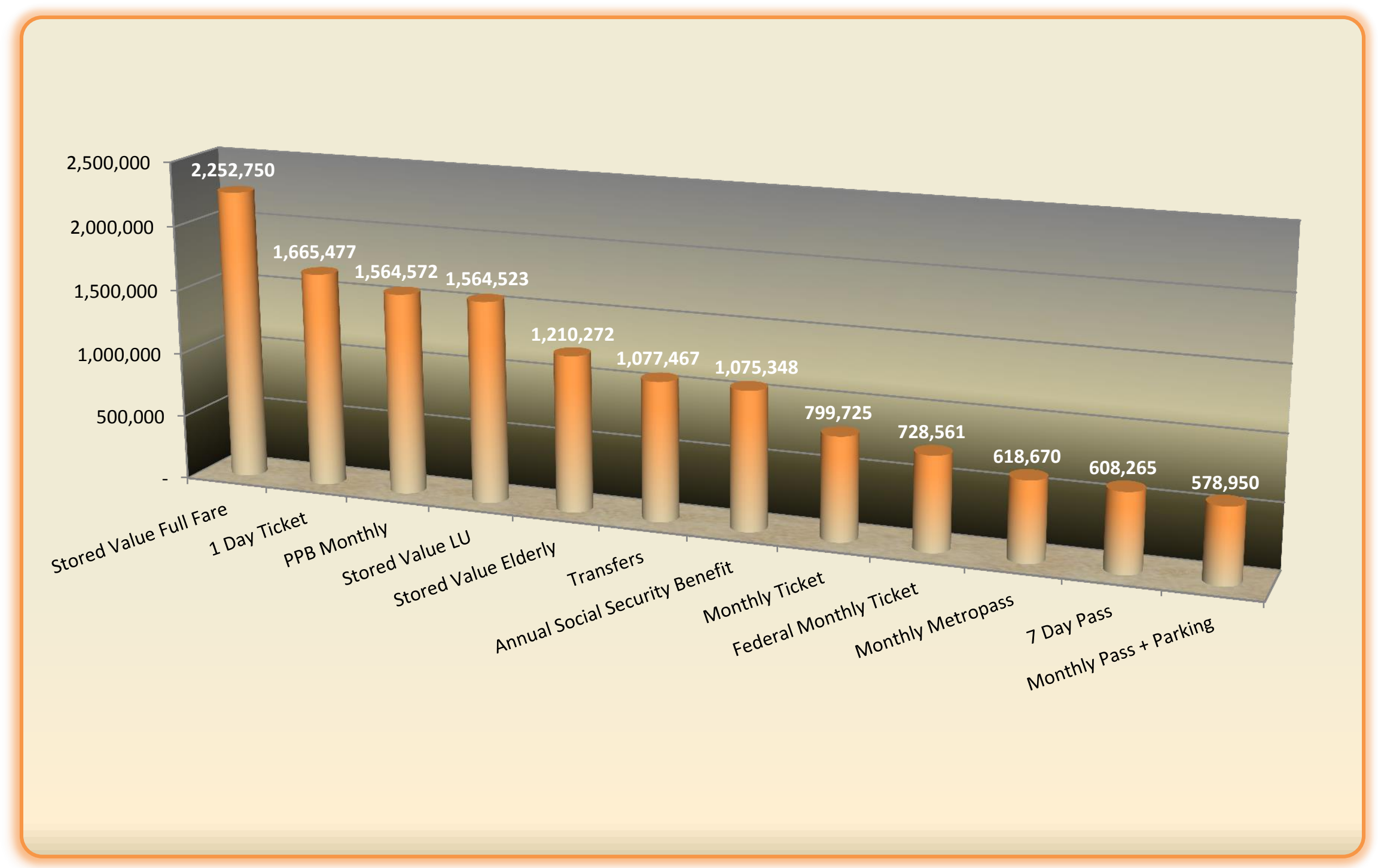

Figure 3-4. Ridership by Most Utilized Fare Categories: EASY Card and EASY Ticket (October 2010 - September 2011) 


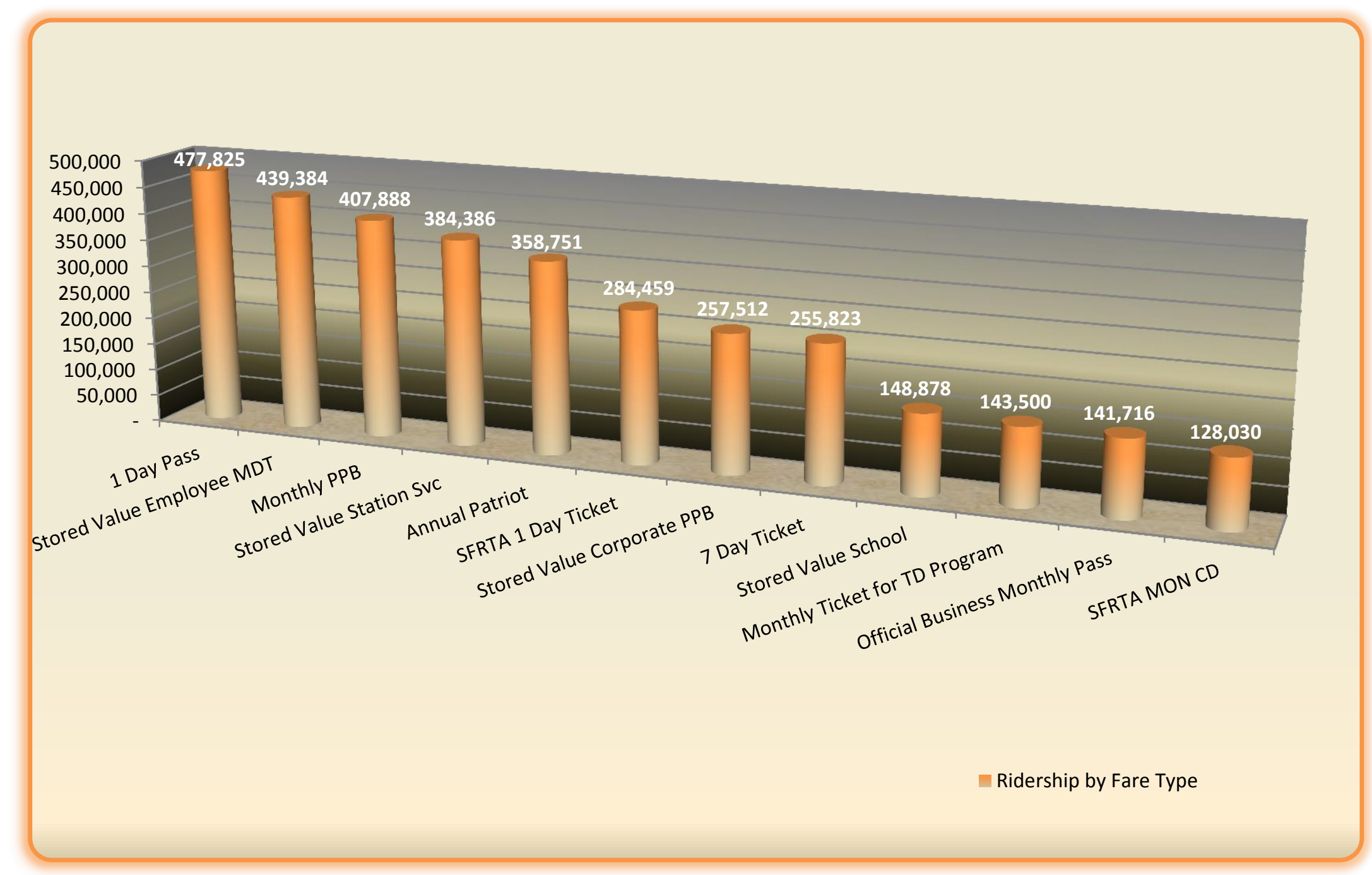

Figure 3-5. Ridership by Next Most Utilized Fare Categories EASY Card and EASY Ticket (October 2010 - September 2011) 
In 2012, the top 24 ridership by fare category accounted for 98-percent of all passenger trips. The top 12 categories ranged from 533,000 to 2,363,000 passenger trips. Once again, Stored Value Full Fare was the highest ridership with 2,363,226 passenger trips, which was 12.6-percent of all passenger trips, decreasing from 12.4-percent in 2011 and 15-percent in 2010. The PPB Monthly (Corporate Discount Program) exceeded 2 million riders with 2,115,364 annual passenger trips. At 4 million passenger trips, the 1 Day Ticket and the Stored Value Limited Use, both EASY Tickets, were the third and fourth highest riderahip by fare category.

In the second tier of highest ridership by fare category, use of the 7 Day Ticket (EASY Ticket) increased from 255,800 in 2011 to 343,400 in 2012. Also, Stored Value School went from 148,900 passenger trips to 186,500 passenger trips. This is the program for $\mathrm{K}$ through 12 students. Figure 3-6 and 3-7 display the top 24 ridership by fare categories for 2012 . 


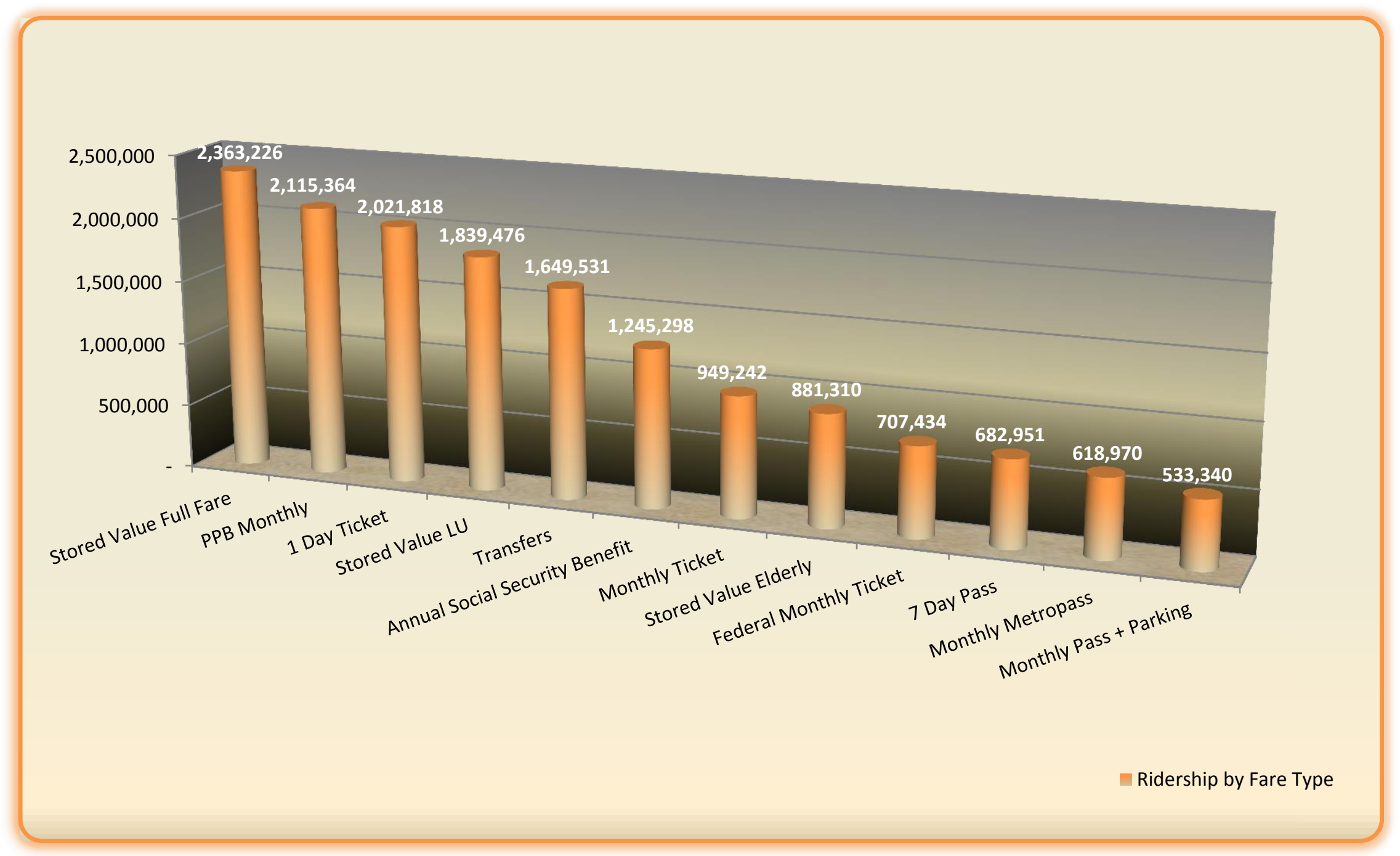

Figure 3-6. Ridership by Most Utilized Fare Categories: EASY Card and EASY Ticket (October 2011 - September 2012) 


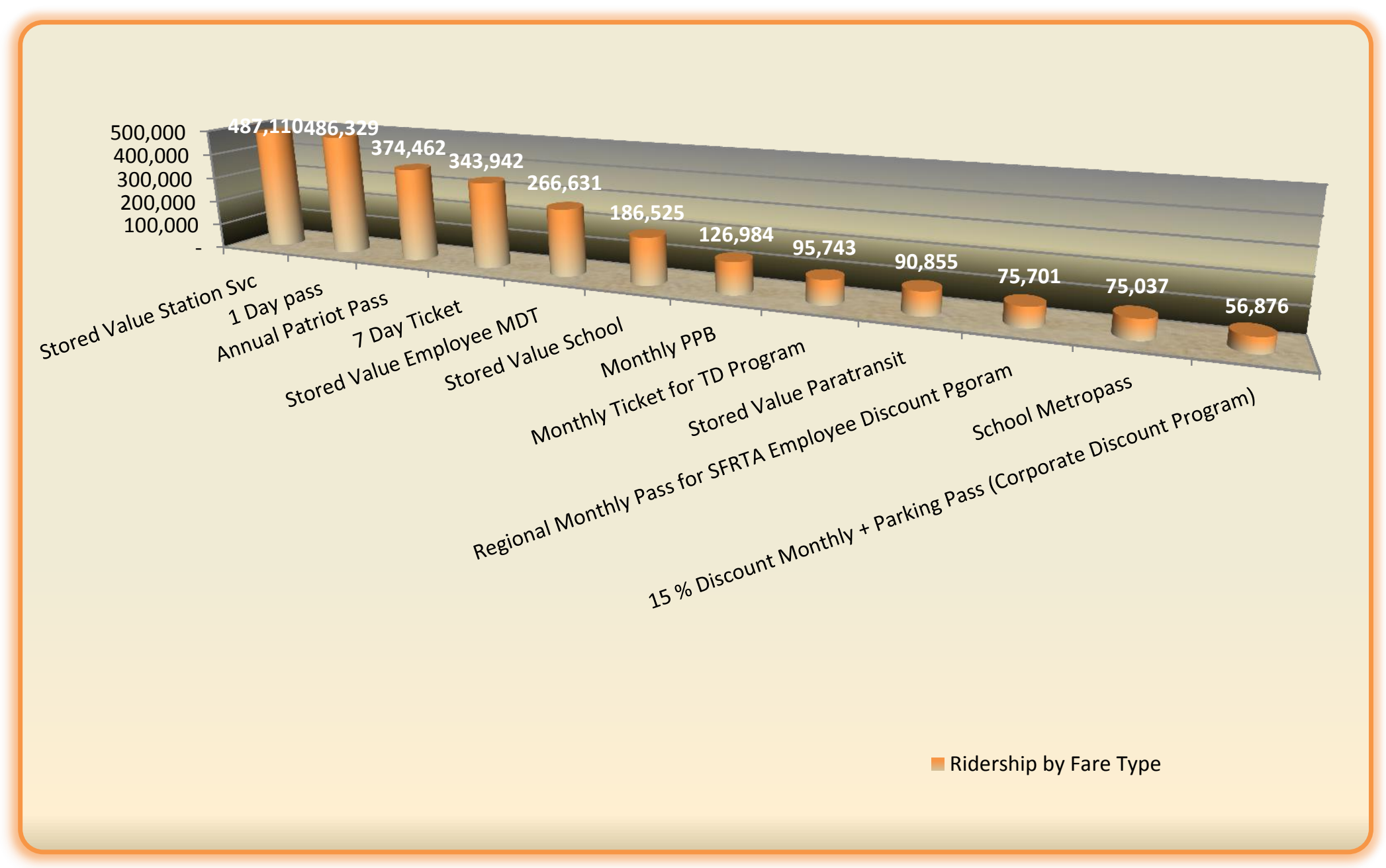

Figure 3-7 . Ridership by Next Most Utilized Fare Categories - EASY Card and EASY Ticket(October 2011September 2012) 


\section{Ridership Impacts - Metrobus}

In the Metrobus data supplied by MDT, there were summary tables of ridership in terms of cash boardings and non-cash boardings. For purposes of comparison, data for FY 2011 and FY 2012 are presented below in Tables 3-1 and 3-2. However, MDT also provided a key to fare categories that included a total of four general fare types: Cash, EASY Card, EASY Ticket, and Paper CSC (determined to be EASY Ticket). Therefore, all non-cash boardings in the summary table would include the three fare types that are not cash.

Table 3-1: Summary of Cash vs. Non-cash Boardings FY 2011

\begin{tabular}{|r|r|r|r|r|r|c|c|}
\hline $\begin{array}{r}\text { FY10-11 } \\
\text { Month }\end{array}$ & $\begin{array}{r}\text { Cash Product } \\
\text { Bus Boardings }\end{array}$ & $\begin{array}{c}\text { Non-cash Bus } \\
\text { Boardings }\end{array}$ & $\begin{array}{c}\text { Bus Total } \\
\text { Boardings }\end{array}$ & $\begin{array}{c}\text { Cash } \\
\text { Collected }\end{array}$ & $\begin{array}{c}\text { Avg. Per } \\
\text { Rider }\end{array}$ & $\begin{array}{c}\% \text { of Cash } \\
\text { Boarding }\end{array}$ & $\begin{array}{c}\% \text { of Non- } \\
\text { Cash } \\
\text { Boarding }\end{array}$ \\
\hline Oct-10 & $1,887,180$ & $4,542,264$ & $6,429,444$ & $\$ 3,190,798$ & $\$ 1.69$ & $29 \%$ & $71 \%$ \\
\hline Nov-10 & $1,820,091$ & $4,352,782$ & $6,172,873$ & $\$ 3,092,918$ & $\$ 1.70$ & $29 \%$ & $71 \%$ \\
\hline Dec-10 & $1,829,667$ & $4,136,114$ & $5,965,781$ & $\$ 3,114,964$ & $\$ 1.70$ & $31 \%$ & $69 \%$ \\
\hline Jan-11 & $1,926,829$ & $4,324,867$ & $6,251,696$ & $\$ 3,262,866$ & $\$ 1.69$ & $31 \%$ & $69 \%$ \\
\hline Feb-11 & $1,870,885$ & $4,294,495$ & $6,165,380$ & $\$ 3,157,610$ & $\$ 1.69$ & $30 \%$ & $70 \%$ \\
\hline Mar-11 & $2,103,012$ & $4,793,286$ & $6,896,298$ & $\$ 3,575,752$ & $\$ 1.70$ & $30 \%$ & $70 \%$ \\
\hline Apr-11 & $1,945,390$ & $4,534,356$ & $6,479,746$ & $\$ 3,285,466$ & $\$ 1.69$ & $30 \%$ & $70 \%$ \\
\hline May-11 & $1,948,247$ & $4,517,268$ & $6,465,515$ & $\$ 3,302,114$ & $\$ 1.69$ & $30 \%$ & $70 \%$ \\
\hline Jun-11 & $1,841,358$ & $4,380,083$ & $6,221,441$ & $\$ 3,147,321$ & $\$ 1.71$ & $30 \%$ & $70 \%$ \\
\hline Jul-11 & $1,820,831$ & $4,204,704$ & $6,025,535$ & $\$ 3,124,028$ & $\$ 1.72$ & $30 \%$ & $70 \%$ \\
\hline Aug-11 & $1,960,555$ & $4,424,146$ & $6,384,701$ & $\$ 3,366,673$ & $\$ 1.72$ & $31 \%$ & $69 \%$ \\
\hline Sep-11 & $1,922,079$ & $4,613,117$ & $6,535,196$ & $\$ 3,260,853$ & $\$ 1.70$ & $29 \%$ & $71 \%$ \\
\hline & $22,876,124$ & $53,117,482$ & $75,993,606$ & $\$ 38,881,365$ & & $30 \%$ & $70 \%$ \\
\hline
\end{tabular}

Table 3-2: Summary of Cash vs. Non-cash Boardings FY 2012

\begin{tabular}{|r|r|r|r|r|r|r|r|}
\hline $\begin{array}{r}\text { FY11-12 } \\
\text { Month }\end{array}$ & $\begin{array}{c}\text { Cash Product } \\
\text { Bus Boardings }\end{array}$ & $\begin{array}{c}\text { Non-cash Bus } \\
\text { Boardings }\end{array}$ & $\begin{array}{c}\text { Bus Total } \\
\text { Boardings }\end{array}$ & $\begin{array}{c}\text { Cash } \\
\text { Collected }\end{array}$ & $\begin{array}{c}\text { Avg. Per } \\
\text { Rider }\end{array}$ & $\begin{array}{c}\% \text { of Cash } \\
\text { Boarding }\end{array}$ & $\begin{array}{c}\text { Cof } \\
\text { Cash } \\
\text { Boarding }\end{array}$ \\
\hline Oct-11 & $1,929,041$ & $4,589,344$ & $6,518,385$ & $\$ 3,274,423$ & $\$ 1.70$ & $30 \%$ & $70 \%$ \\
\hline Nov-11 & $1,942,137$ & $4,641,721$ & $6,583,858$ & $\$ 3,316,282$ & $\$ 1.71$ & $29 \%$ & $71 \%$ \\
\hline Dec-11 & $1,963,969$ & $4,540,064$ & $6,504,033$ & $\$ 3,377,208$ & $\$ 1.72$ & $30 \%$ & $70 \%$ \\
\hline Jan-12 & $2,022,316$ & $4,614,252$ & $6,636,568$ & $\$ 3,467,393$ & $\$ 1.71$ & $30 \%$ & $70 \%$ \\
\hline Feb-12 & $1,979,457$ & $4,534,238$ & $6,513,695$ & $\$ 3,391,453$ & $\$ 1.71$ & $30 \%$ & $70 \%$ \\
\hline Mar-12 & $2,112,998$ & $4,897,978$ & $7,010,976$ & $\$ 3,626,541$ & $\$ 1.72$ & $30 \%$ & $70 \%$ \\
\hline May-12 & $1,909,466$ & $4,576,779$ & $6,486,245$ & $\$ 3,273,288$ & $\$ 1.71$ & $29 \%$ & $71 \%$ \\
\hline Jun-12 & $1,942,270$ & $4,631,182$ & $6,573,452$ & $\$ 3,339,665$ & $\$ 1.72$ & $30 \%$ & $70 \%$ \\
\hline Jul-12 & $1,795,906$ & $4,352,473$ & $6,148,379$ & $\$ 3,112,695$ & $\$ 1.73$ & $29 \%$ & $71 \%$ \\
\hline Aug-12 & $1,854,910$ & $4,523,859$ & $6,378,769$ & $\$ 3,313,722$ & $\$ 1.79$ & $29 \%$ & $71 \%$ \\
\hline Sep-12 & $1,751,961$ & $4,545,025$ & $6,296,986$ & $\$ 3,169,852$ & $\$ 1.81$ & $28 \%$ & $72 \%$ \\
\hline & $23,027,496$ & $54,834,363$ & $77,861,859$ & $\$ 39,833,747$ & & $30 \%$ & $70 \%$ \\
\hline
\end{tabular}


MDT also supplied 24 months of data at the route level that included every fare category for every route for every month. Together the data was comprised of more than 137,000 individual records. It was the desire of the NCTR project team to devise a methodology by which data could be reported for three general fare types: Cash, EASY Card, and EASY Ticket (since Paper CSC is EASY Ticket). This was completed by taking the 137,000 records and placing them into Microsoft Access, a database management software. Each fare type was coded to have a unique identifier and then coded as one of the three fare type categories. This methodology generated the ridership data provided in Figure 3-8 below.

Using the NCTR team methodology, cash boardings were about 4-percent greater than the cash ridership reported by MDT in Tables 3-1 and 3-2 above. However, total ridership in annual passenger trips was identical to MDT's data and the breakdown was almost perfect. In 2011 and 2012, MDT had cash boardings at 30-percent and non-cash boardings at 70percent. In 2011 and 2012, NCTR's methodology had cash boardings at 31-percent and EASY Card/EASY Ticket at 69 percent. Therefore, the NCTR project team concluded that the margin of error was small enough to report the figures below since it is so important to this research effort to know the penetration of EASY Card and EASY Ticket.

Figure 3-8 displays the breakdown of ridership by Cash, EASY Card, and EASY Ticket. Cash ridership grew from 23.8 to 24.0 million between 2011 and 2012. EASY Card was the most utilized fare media at 41.2 million passenger trips in 2011 which grew to 42.4 million in 2012. EASY Ticket ridership was 11.0 million in 2011 and grew to 11.5 million in 2012 .

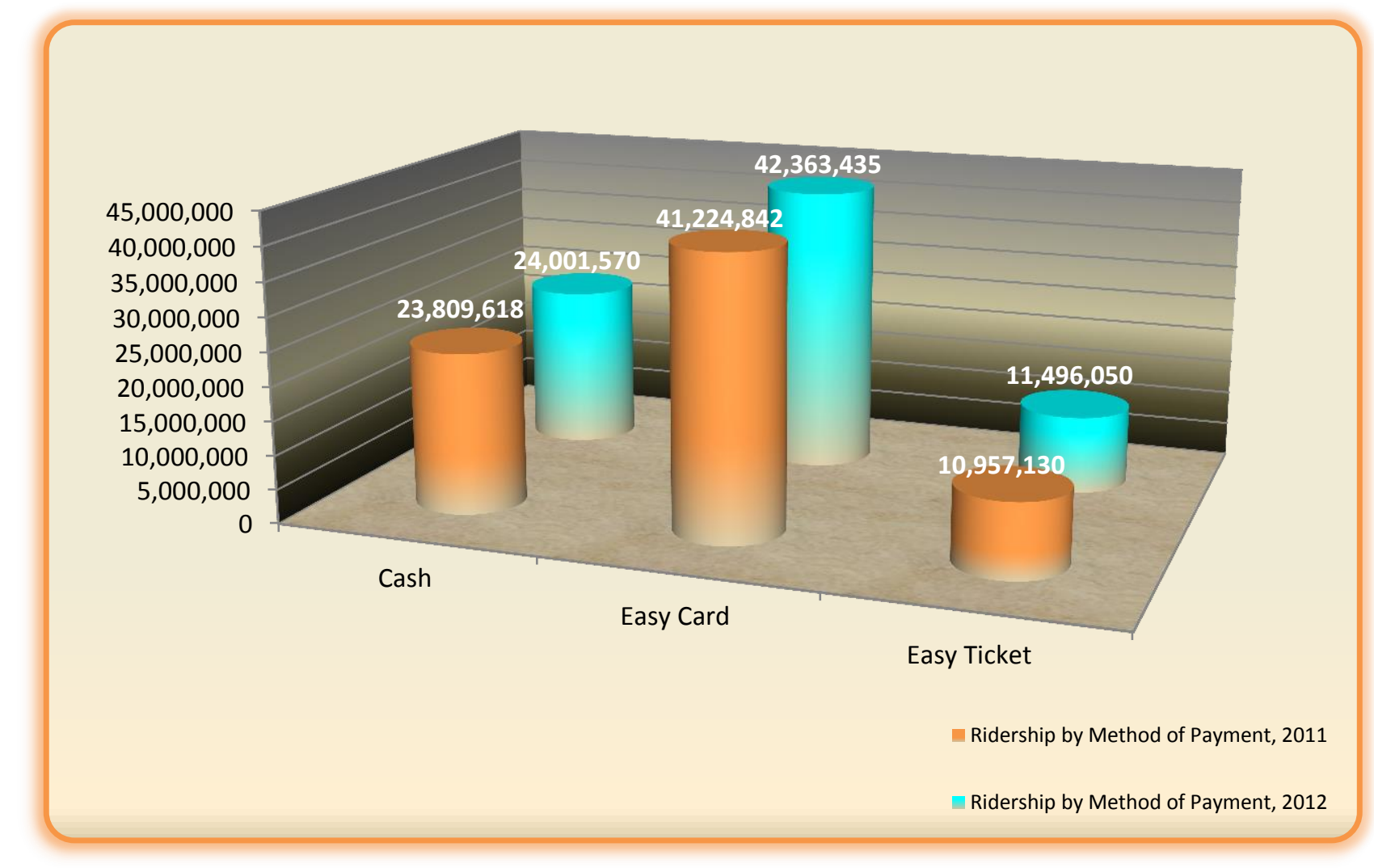

Figure 3-8. Ridership by Method of Payment, FY 2011-2012 
Next, the ridership figures were broken down by percentage of overall ridership between 2011 and 2012. In 2011, cash ridership was 31-percent of all ridership, EASY Card was 54percent, and EASY Ticket was 15-percent (see Figure 3-9 below). Figure 3-10 shows that when combined, EASY Card and EASY Ticket ridership was 69-percent of all Metrobus passenger trips.

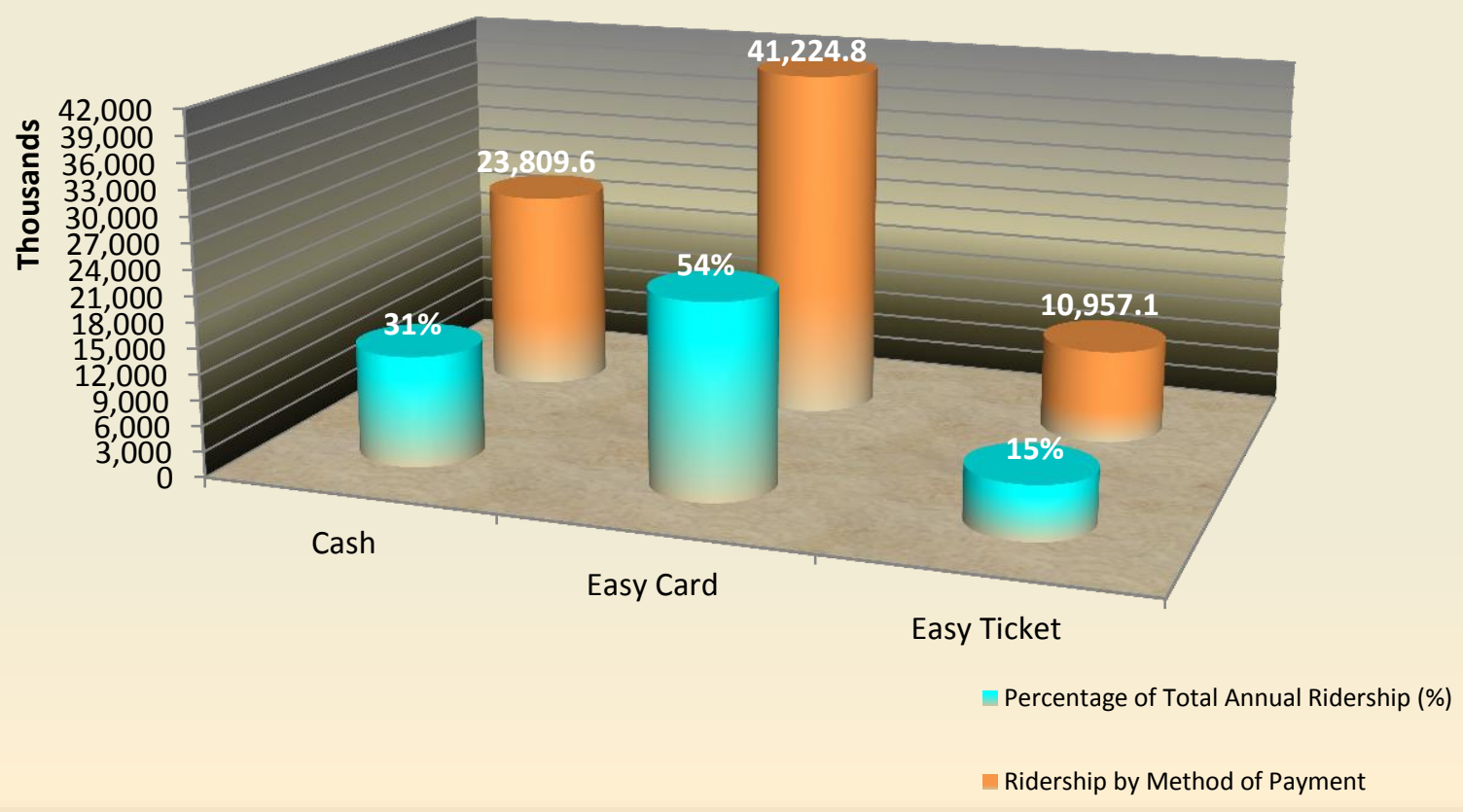

Figure 3-9. Total Annual Ridership (in millions) by Method of Payment and as a Percentage of Total Trips (FY 2011) 


\section{RIDERSHIP IMPACTS OF SOUTH FLORIDA'S EASY SMART CARD}

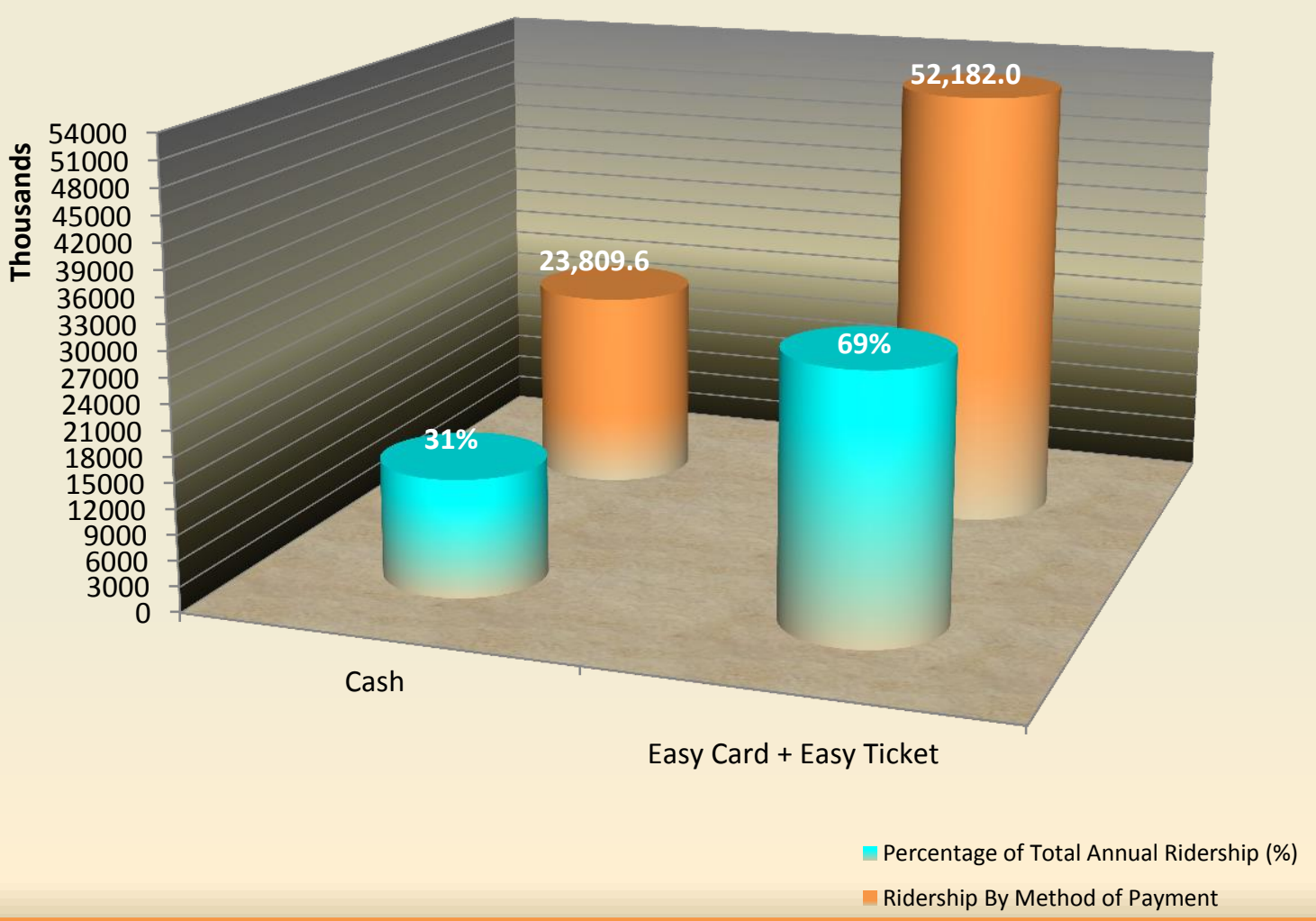

Figure 3-10. Total Annual Ridership by Method of Payment and as a Percentage of Total Trips (FY 2011) 
In 2012, cash ridership held steady at 31-percent while EASY Card ridership remained at 54-percent and EASY Ticket was 15-percent (Figure 3-11). Figure 3-12 below shows that EASY Card and EASY Ticket combined comprised 69-percent of all passenger trips in 2012.

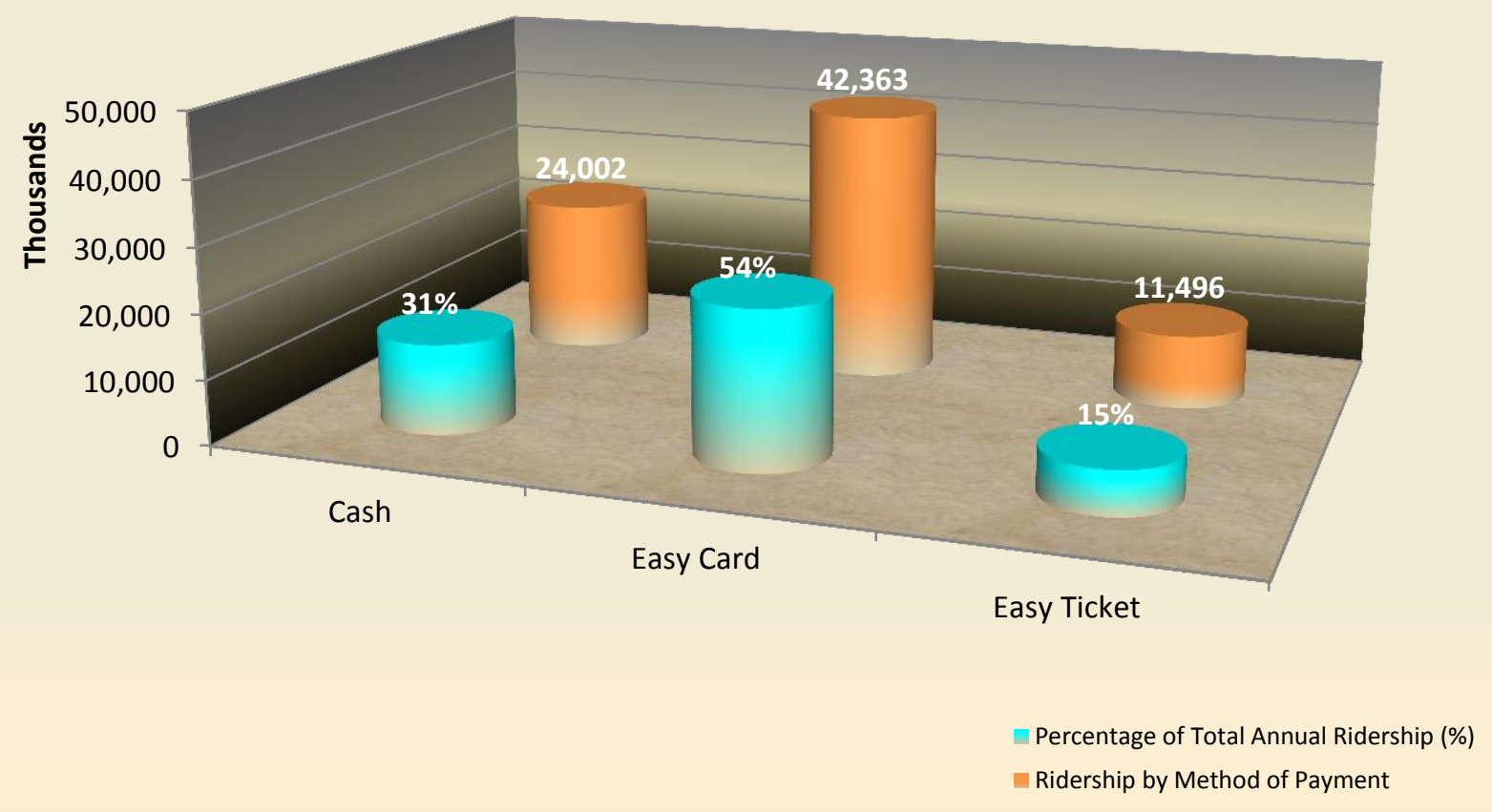

Figure 3-11. Total Annual Ridership by Method of Payment and as a Percentage of Total Trips (FY 2012) 


\section{RIDERSHIP IMPACTS OF SOUTH FLORIDA'S EASY SMART CARD}

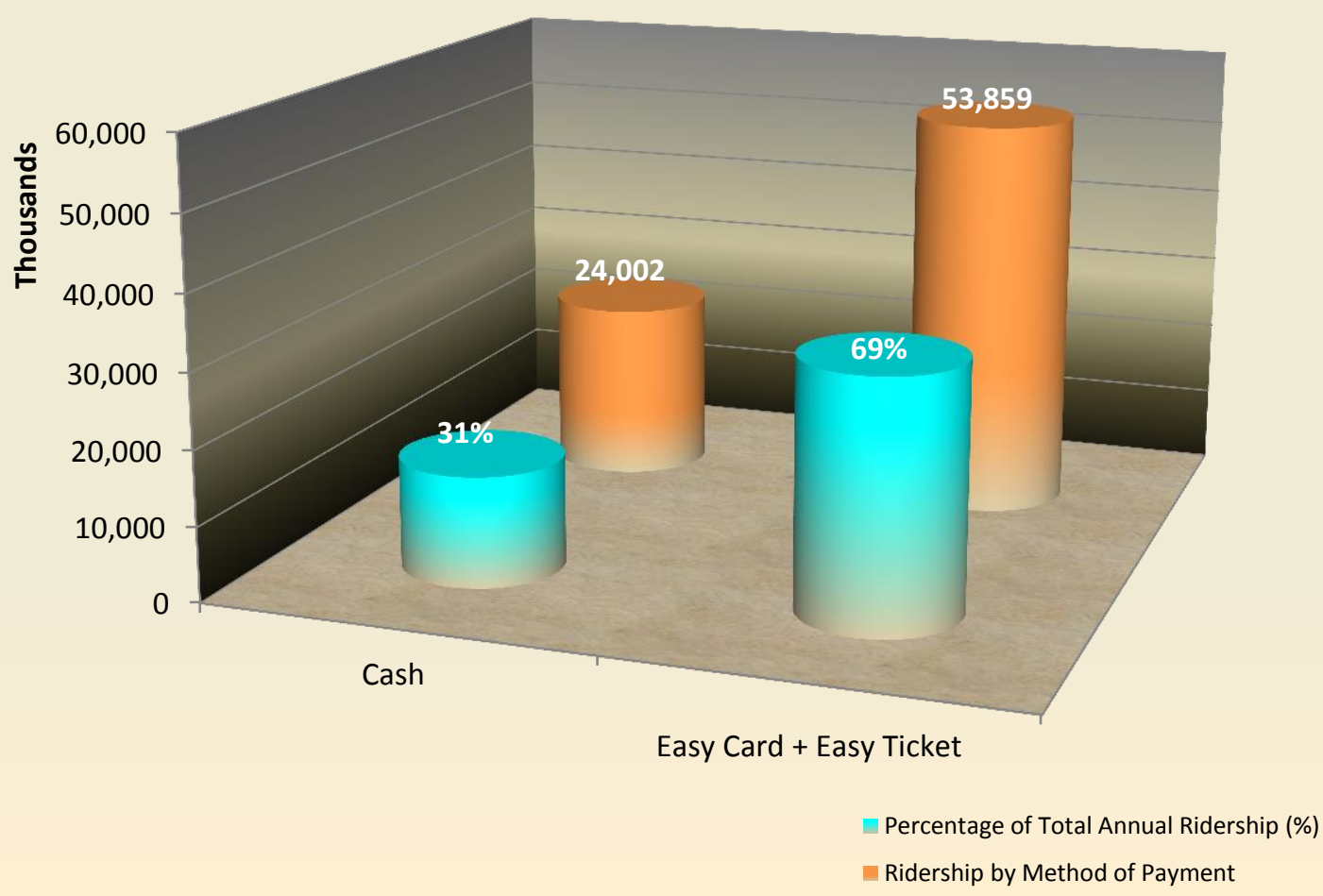

Figure 3-12. Total Annual Ridership by Method of Payment and as a Percentage of Total Trips (FY 2012)

Figure 3-13 below shows the change in ridership between 2011 and 2012. Cash ridership only grew by 0.81 -percent while EASY Card ridership increased by 2.76 -percent. The most significant changes were that EASY Ticket ridership grew by 30 -percent and paper ridership declined by 6-percent. 


\section{RIDERSHIP IMPACTS OF SOUTH FLORIDA'S EASY SMART CARD}

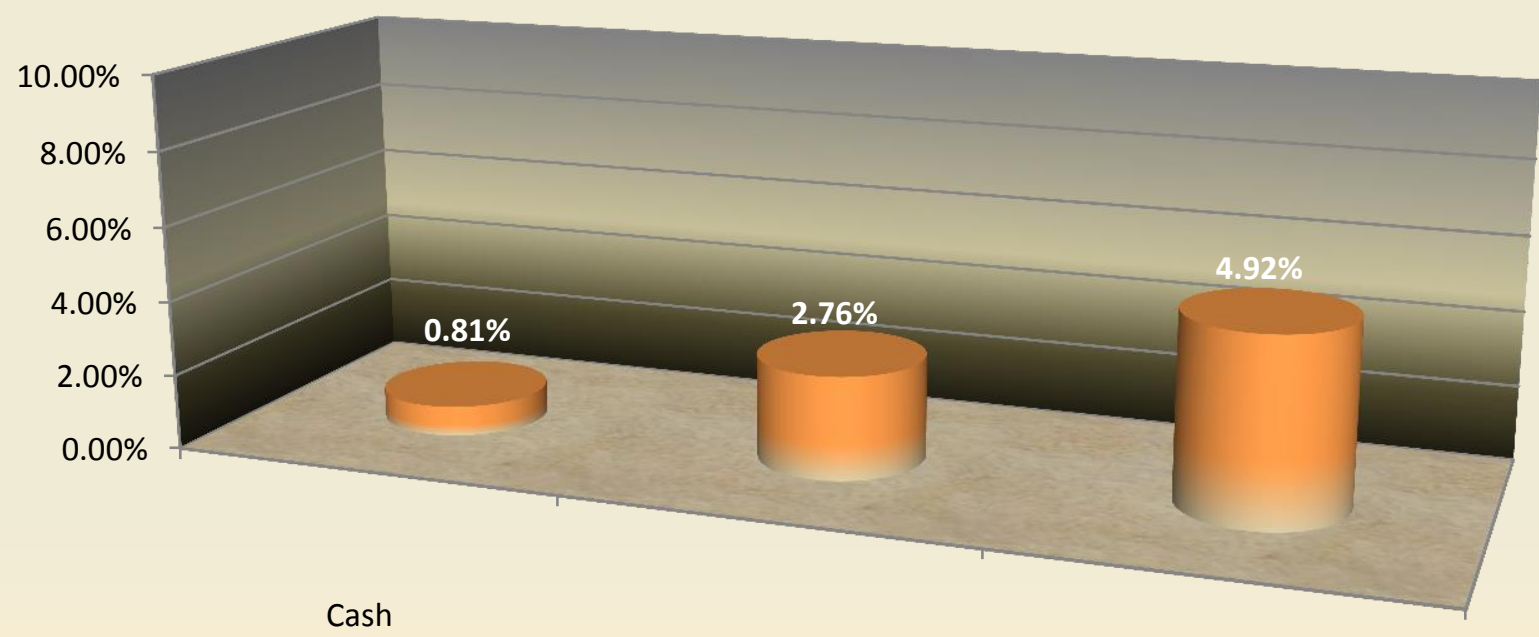

Easy Card

Easy Ticket

Figure 3-13. Percentage Change in Ridership by Method of Payment, FY 2011 - FY 2012

\section{Ridership by Fare Category 2012}

As mentioned earlier, the route level ridership data supplied by MDT constituted 137,000 individual records as ridership by fare category by route was supplied for a 24 month period. CUTR selected 10 of MDT's highest ridership routes in 2012 and aggregated annual ridership with the fare categories generating the highest ridership. See Figures 3-14 through Figure 3-23. The assumption is that the distribution would be reflective of all or most routes. The 10 routes are the Route $3,7,8,9,11,22,27,37,38$ and 77 . Presented below are the commonalities:

- Full cash fare payment appears to be high at the route level; however, it would be necessary to add all of the EASY Card and EASY Ticket categories to place these riders in proportion;

- Free fare categories, such as Annual Social Security Benefit and Stored Value Elderly, are well represented on Metrobus as they are on Metrorail. 


\section{RIDERSHIP IMPACTS OF SOUTH FLORIDA'S EASY SMART CARD}

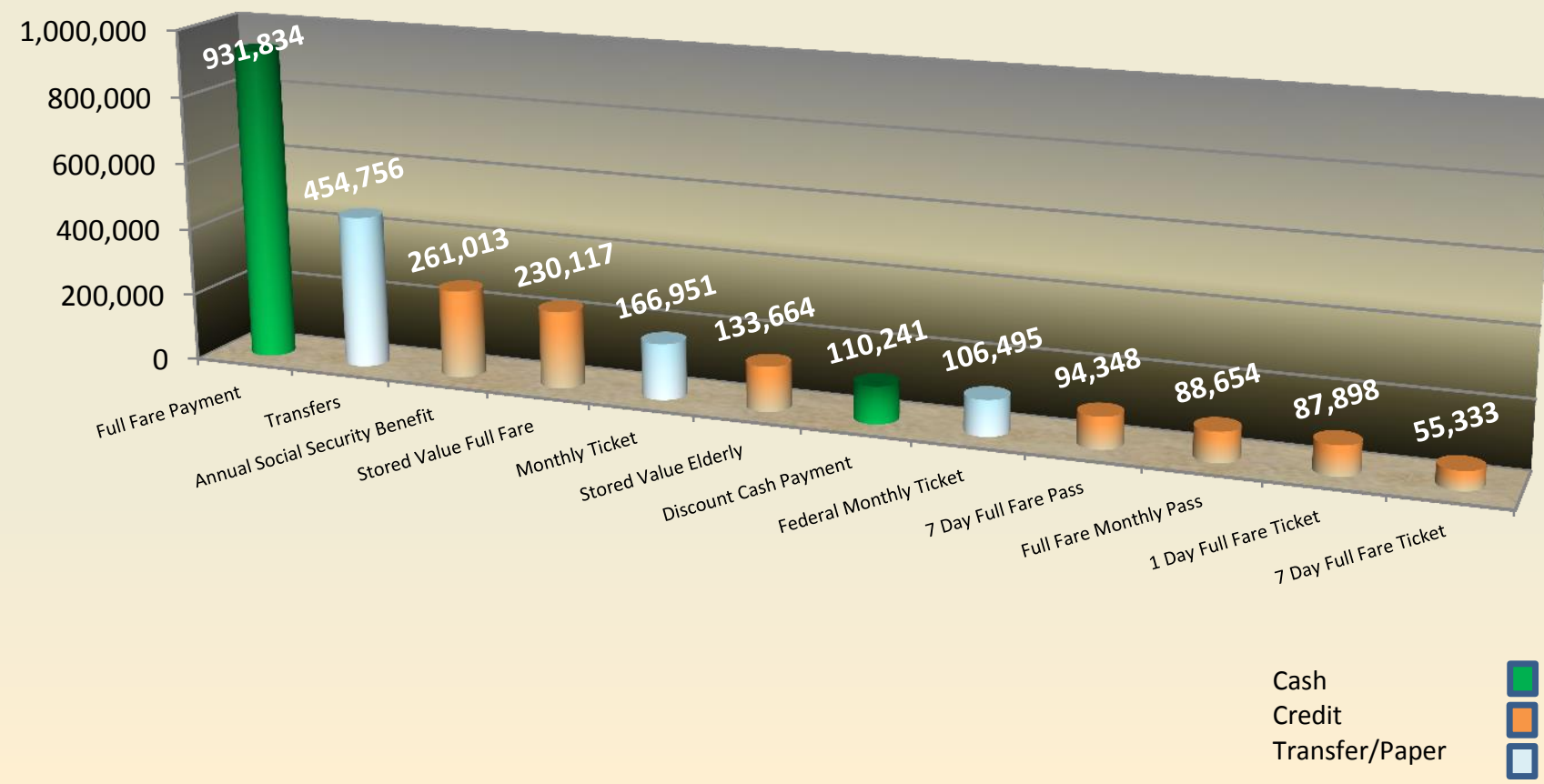

Figure 3-14. Route 3 Highest Ridership Levels by Fare Category, FY 2012 


\section{RIDERSHIP IMPACTS OF SOUTH FLORIDA'S EASY SMART CARD}

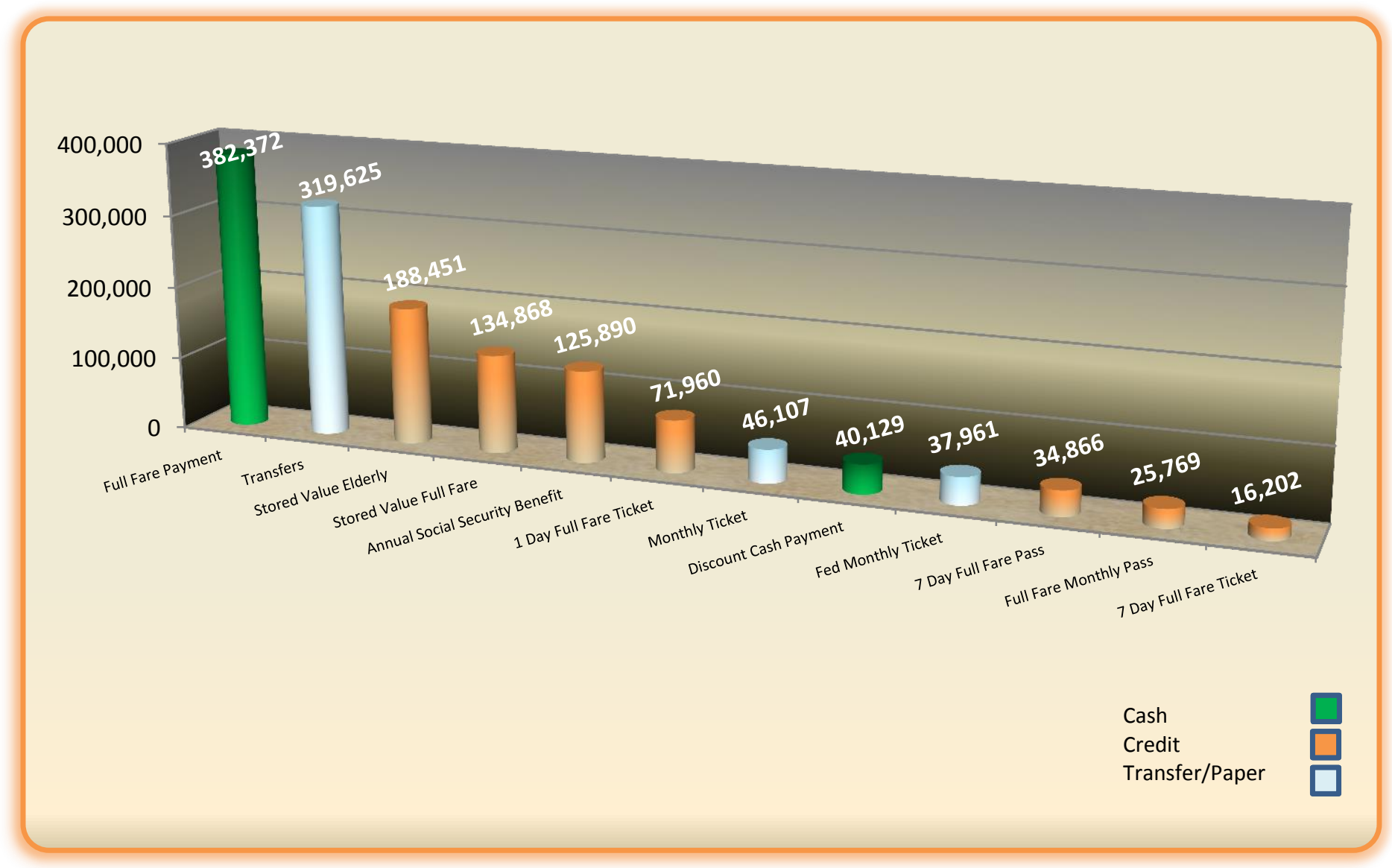

Figure 3-15. Route 7 Highest Ridership Levels by Fare Category, FY 2012 


\section{RIDERSHIP IMPACTS OF SOUTH FLORIDA'S EASY SMART CARD}

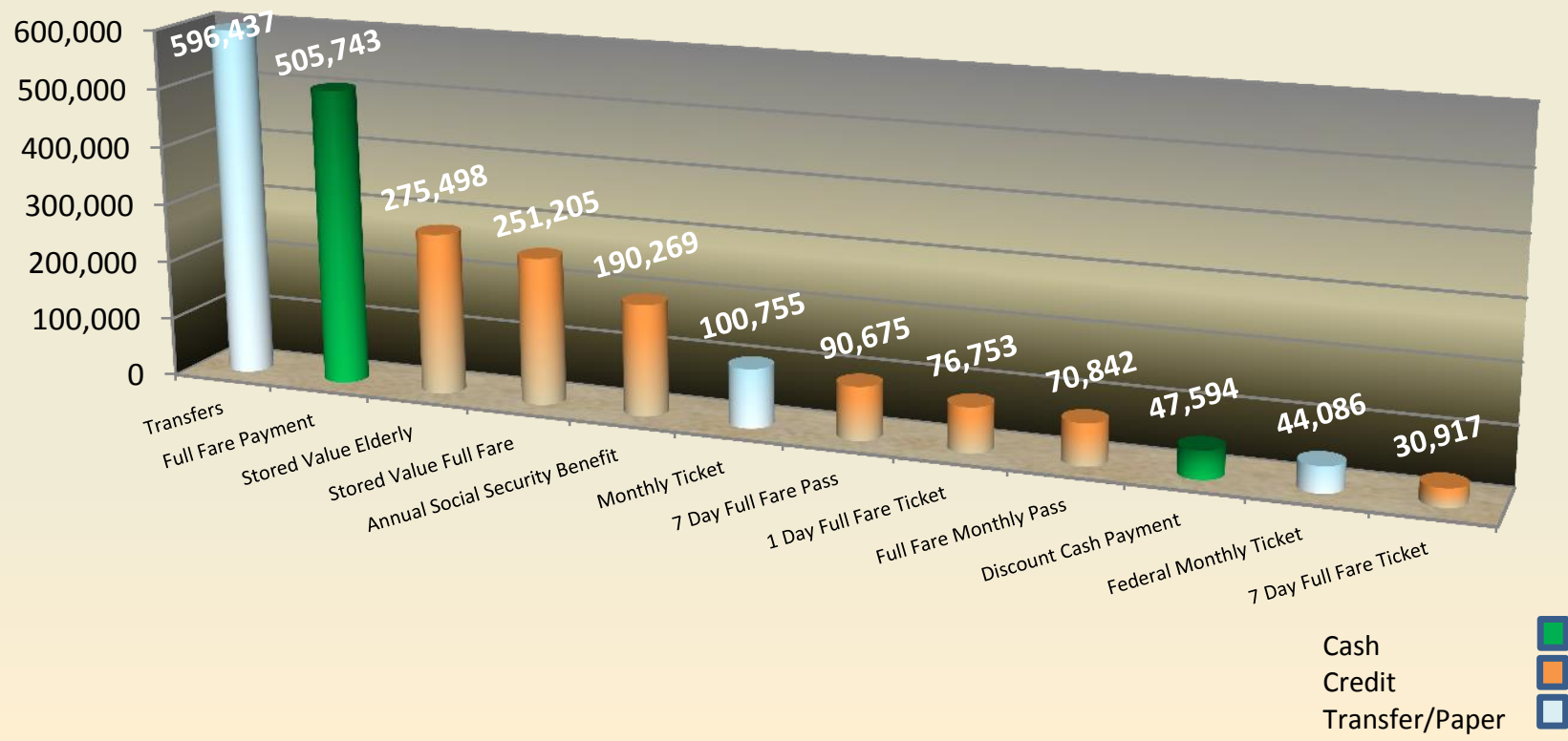

Figure 3-16. Route 8 Highest Ridership Levels by Fare Category, FY 2012

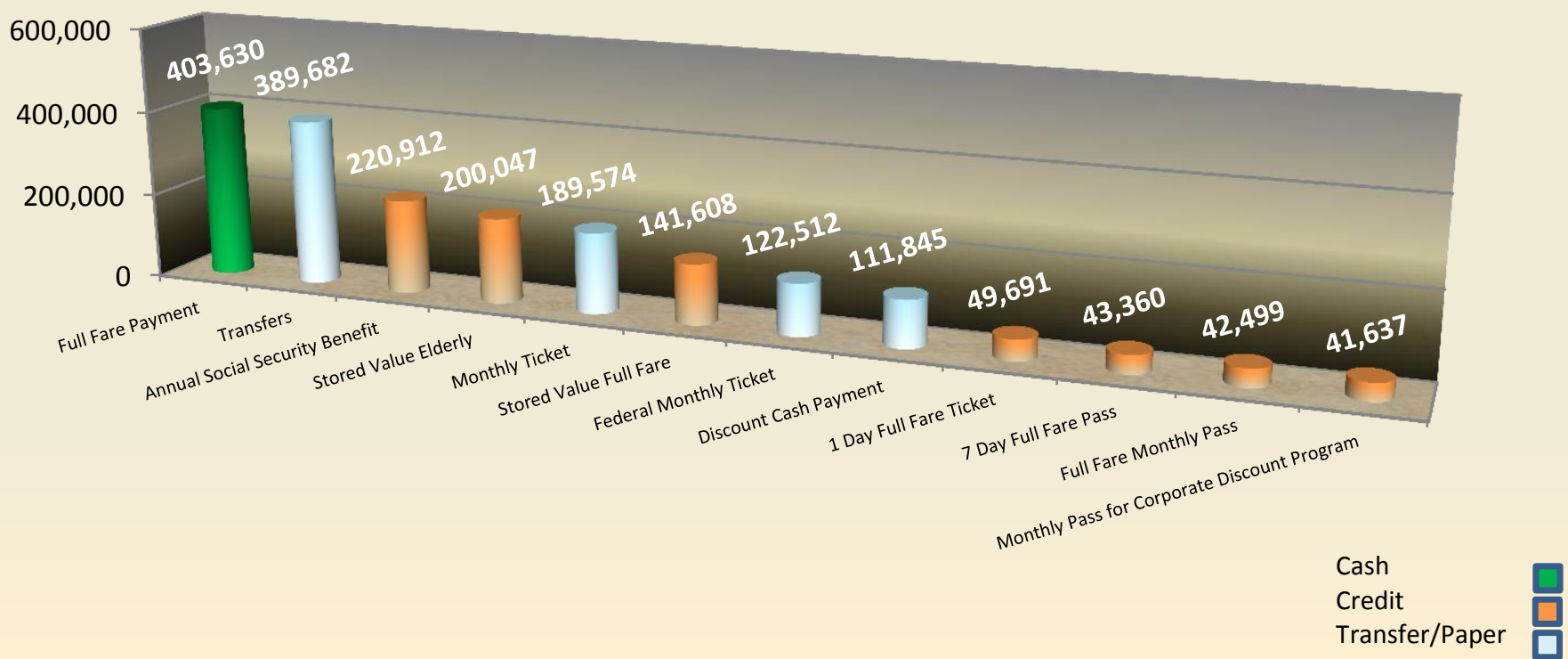

Figure 3-17. Route 9 Highest Ridership Levels by Fare Category, FY 2012 


\section{RIDERSHIP IMPACTS OF SOUTH FLORIDA'S EASY SMART CARD}

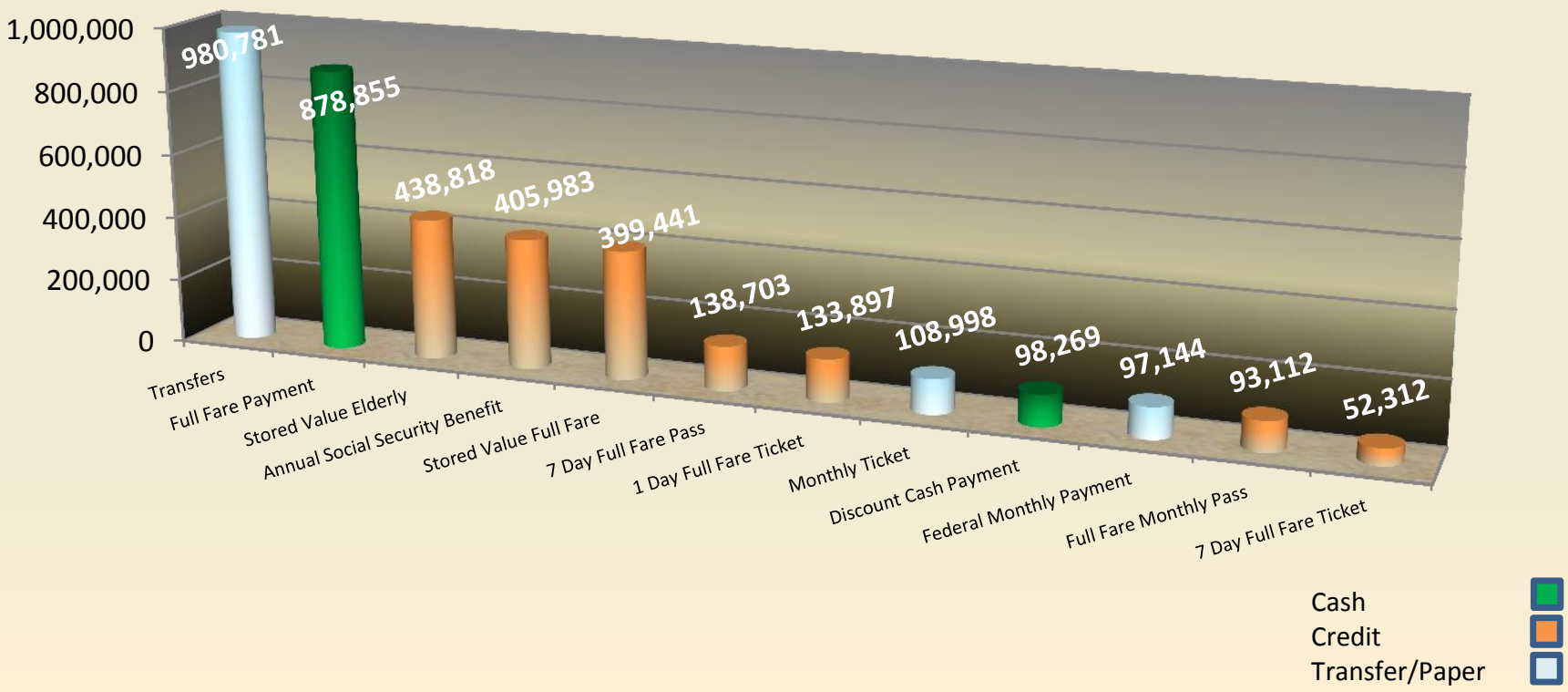

Figure 3-18. Route 11 Highest Ridership Levels by Fare Category, FY 2012

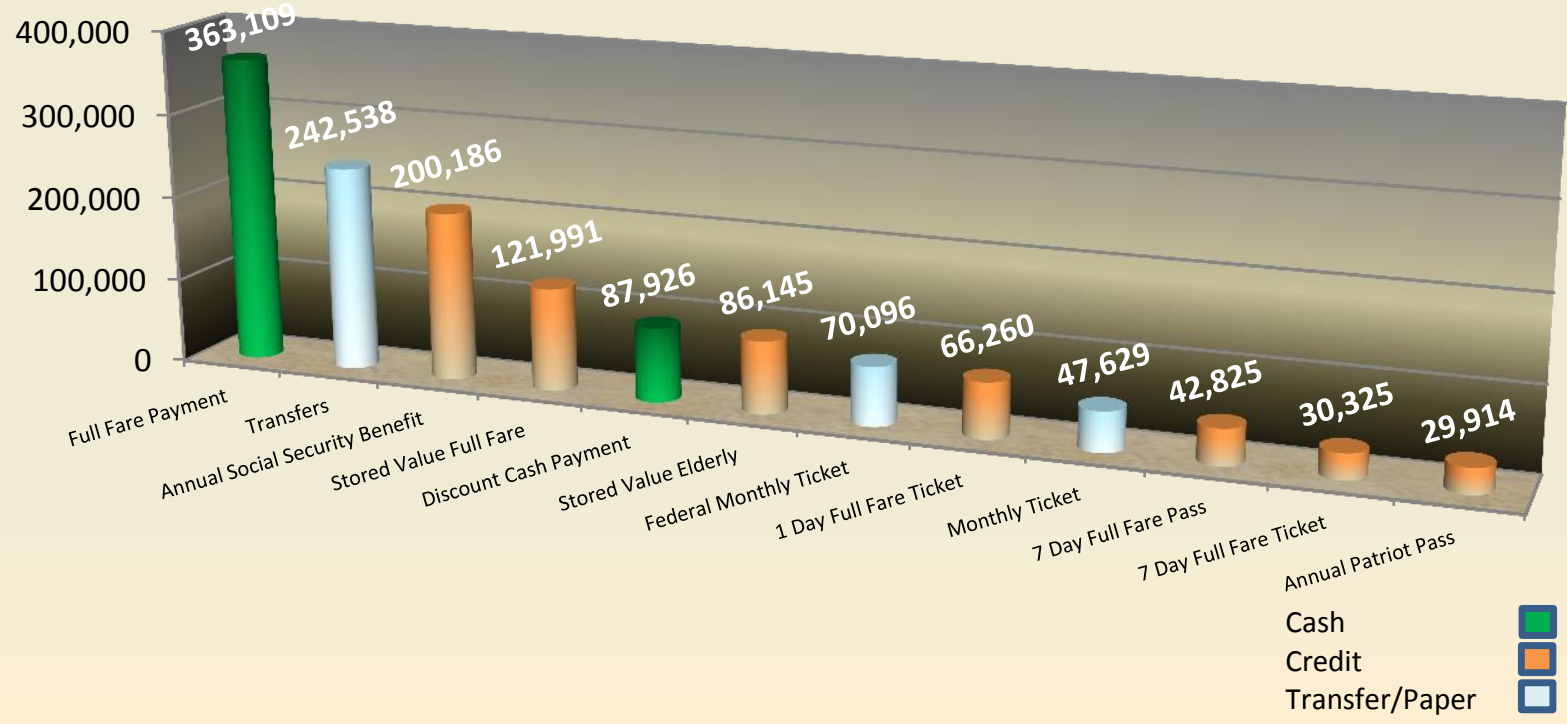

Figure 3-19. Route 22 Highest Ridership Levels by Fare Category, FY 2012 


\section{RIDERSHIP IMPACTS OF SOUTH FLORIDA'S EASY SMART CARD}

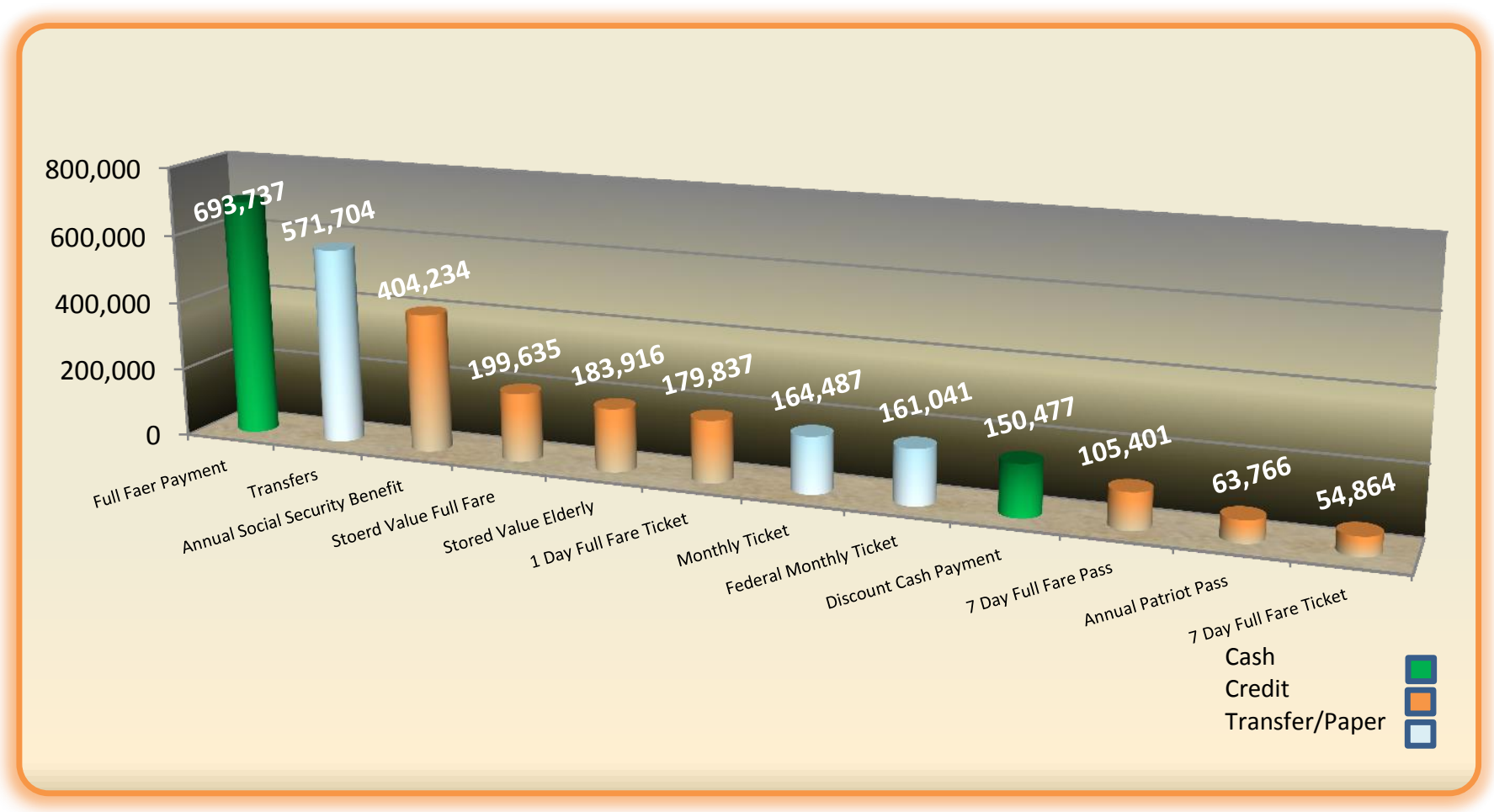

Figure 3-20. Route 27 Highest Ridership Levels by Fare Category, FY 2012

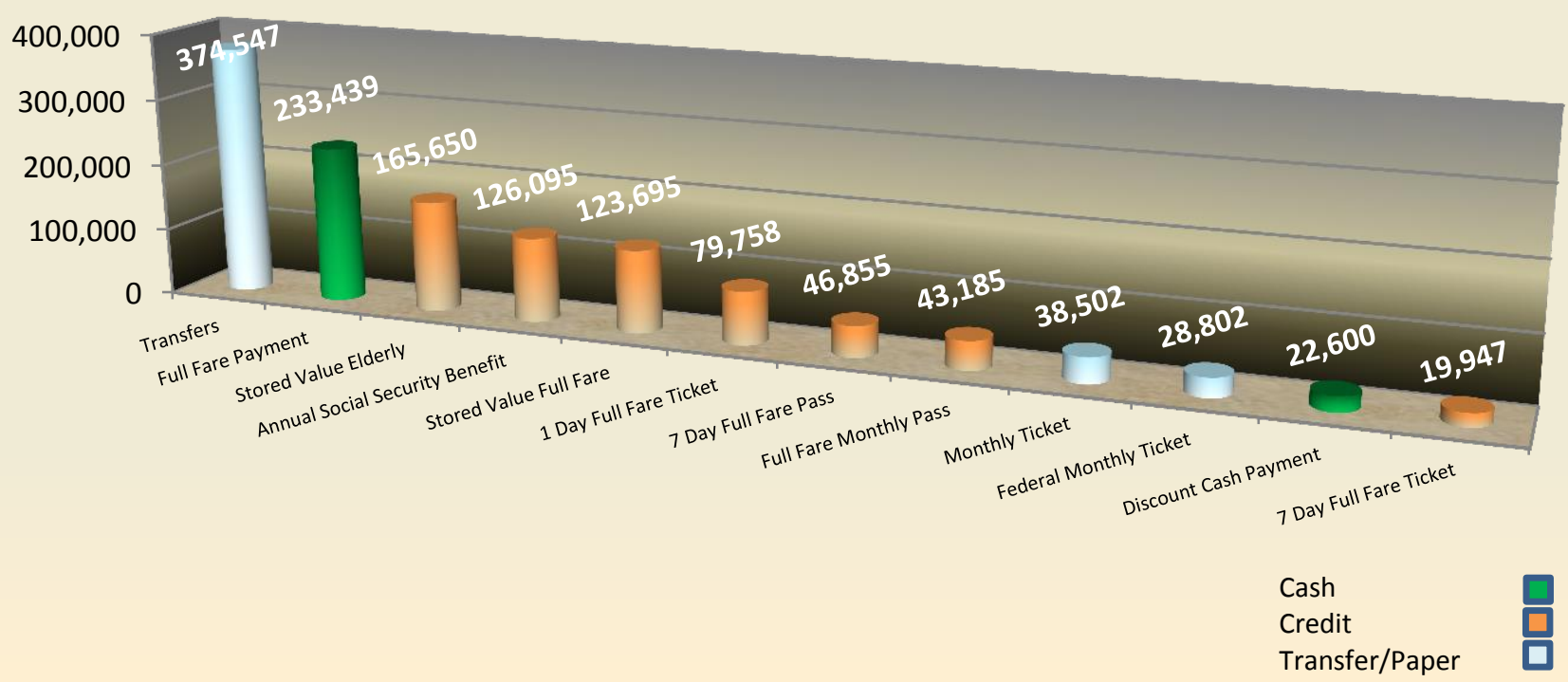

Figure 3-21. Route 37 Highest Ridership Levels by Fare Category, FY 2012 


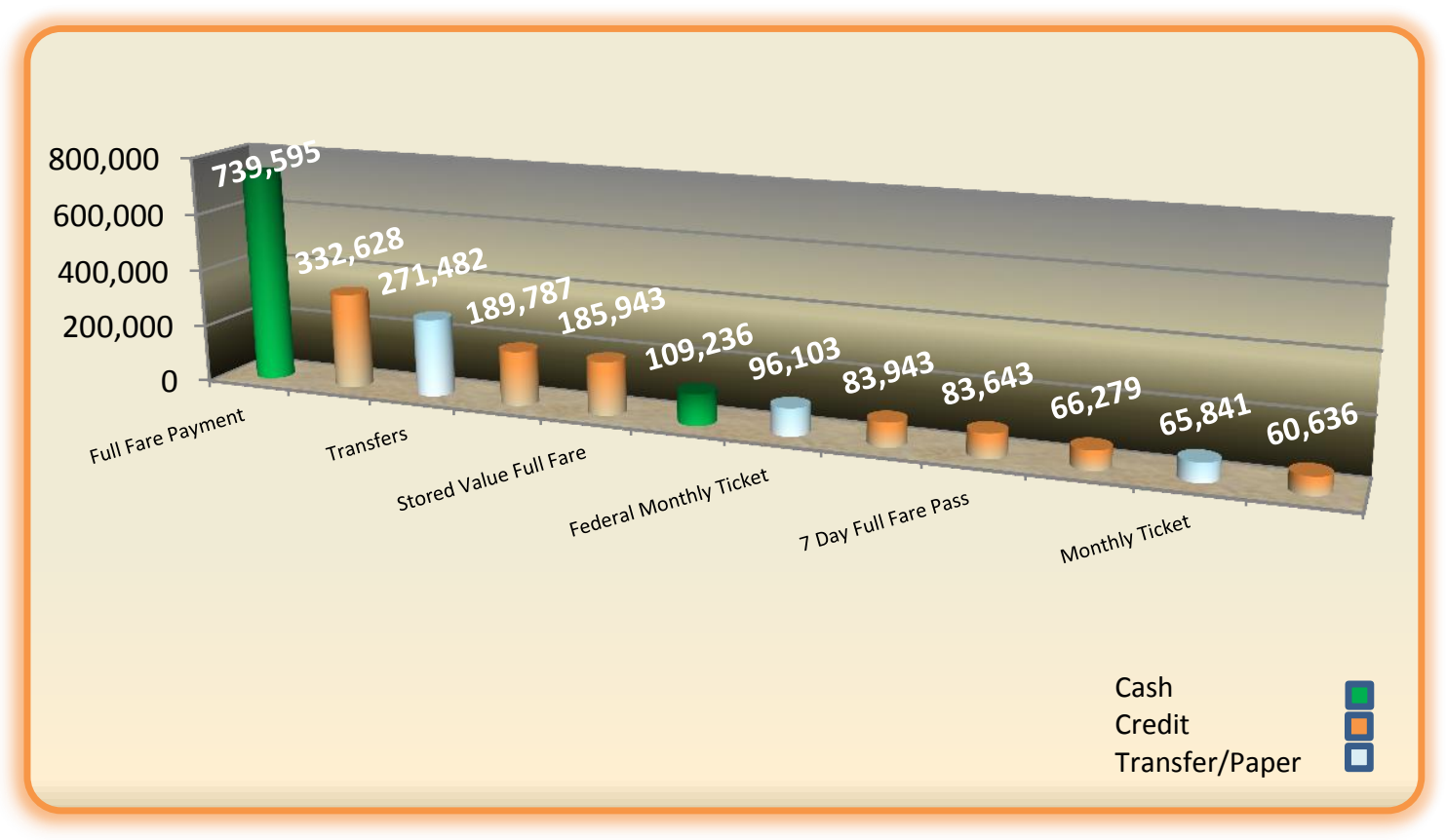

Figure 3-22. Route 38 Highest Ridership Levels by Fare Category, FY 2012

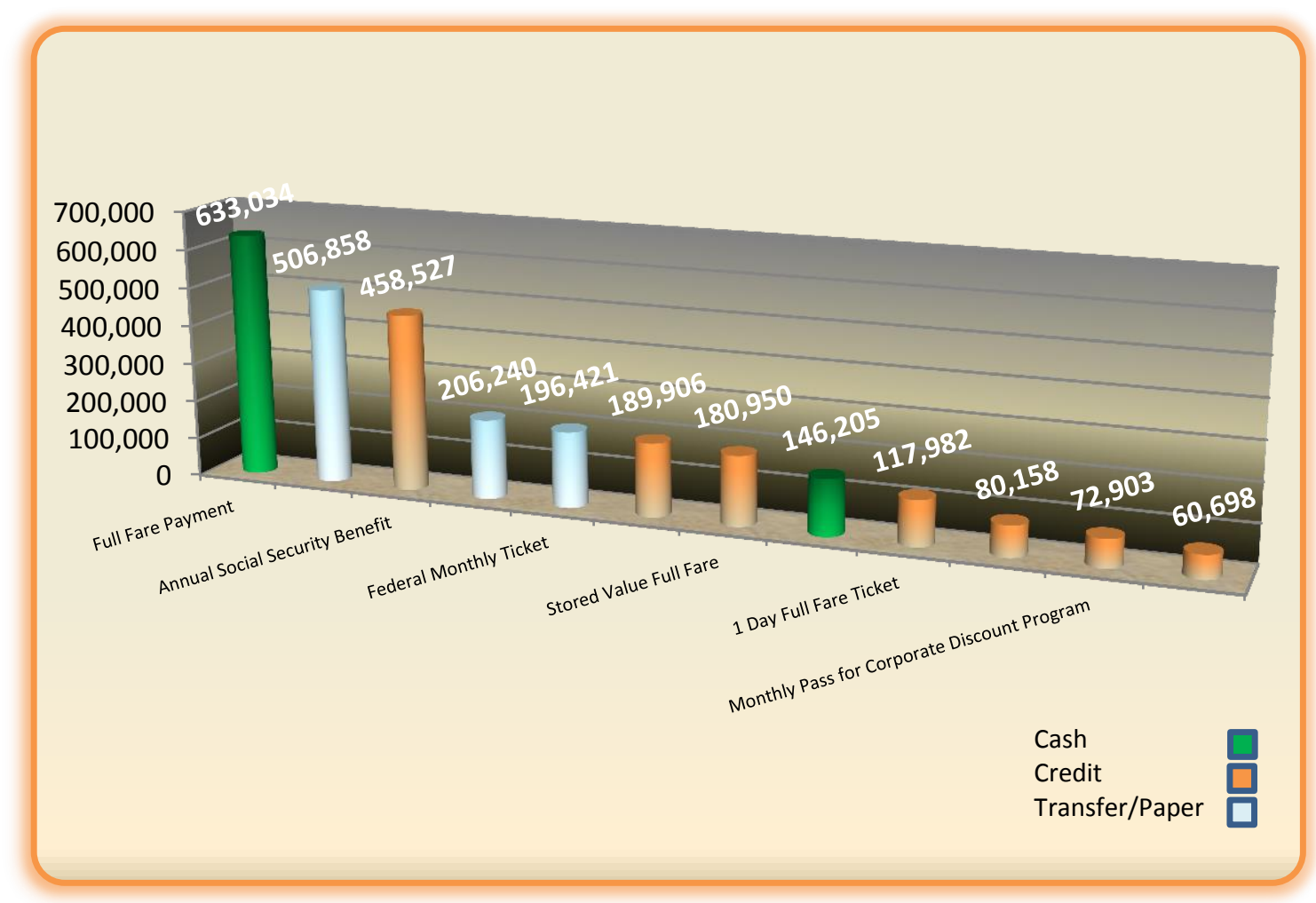

Figure 3-23. Route 77 Highest Ridership Levels by Fare Category, FY 2012 
This page intentionally left blank 


\section{Chapter 4}

\section{Fare Equity and Analysis Activities}

\section{Fare Equity and Analysis Activities}

To ensure equity in terms of EASY Card access, particularly for low income and minority populations, MDT focused on establishing an extensive network of EASY Card sales outlets for customers who don't want to purchase online or can't conveniently travel to other outlets such as Metrorail stations or the Government Center. For example, the Sedano Supermarket chain, popular within the Hispanic community, sells EASY Cards at approximately 26 of its locations. MDT also established a retail account with 32 Advance America Cash Advance outlets that offer pay day loans, primarily to lower income residents in Miami-Dade County.

MDT also conducted training for all call center employees to educate them about antidiscrimination policies and to alert them to any circumstances or practices that could be considered discriminatory. In the event an employee receives a complaint that could be perceived as discriminatory, even if discrimination is not specifically mentioned, call center employees promptly send the complaint directly to MDT's Civil Rights Office and Labor Relations for further investigation and resolution.

Following the introduction of the SFRTA EASY Card in February 2011, SFRTA and MDT entered into a partnership to provide a regional EASY Card that would allow customers wishing to transfer between the two systems to purchase an EASY Card for $\$ 100$ and add a new $\$ 40$ transfer or "link-up" fee good for unlimited travel between the two systems. Previously, SFRTA customers presenting any valid SFRTA ticket from stations located within Miami-Dade County were able to transfer to the MDT system free of charge and SFRTA honored MDT customers transferring to Tri-Rail by allowing them to purchase a SFRTA ticket at a discounted rate of $\$ 1.75$ at any of the five Tri-Rail stations in Miami-Dade County. For those customers who did not purchase a regional pass a new transfer fee was introduced. The Tri-Rail to Metrorail transfers fee was $\$ 1$, to Metrobus, $\$ 0.50$, and to an Express Bus $\$ 0.85$.

Consistent with Title VI of the Civil Rights Act of 1964 as amended which states that "No person in the United States shall, on the grounds of race, color, or national origin be excluded from participation in, be denied the benefits of, or be otherwise subjected to discrimination under, any program to which this part applies", and more specifically the Federal Transit Administration Circular 4702.1149 CFR Section 21.5 MDT was required to conduct a TITLE VI Fare Equity Analysis as a result of the new $\$ 40$ transfer fee associated with the regional EASY Card. The Fare Equity Analysis requires an assessment of the proposed fare change on minority and low income populations, alternatives available for people affected by the fare increase, and a description of actions an agency proposes to mitigate adverse effects. If it is determined there is an adverse effect on minority and low 
income riders, the fare increase can be implemented if the recipient (MDT) demonstrates the action meets a substantial need that is in the public's best interest.

MDT used Census 2000 and the Economic and Social Research Institute's (ESRI) data to identify four Miami-Dade County Tri-Rail stations located within minority census tracts (a geographical area in which the minority demographic is 81.9 percent or higher). The Tri-Rail stations identified included: Golden Glades, Metrorail Tri-Rail Transfer, Opa-Locka and Hialeah Market. The same data sources were also used to identify low income or poverty level census tracts where this demographic group is 15.7 percent or higher. The following three Tri-Rail stations were identified as low income tracts: Golden Glades, Opa-Locka and Hialeah Market.

With the introduction of the SFRTA EASY Card, MDT was able to determine a passenger's point of origin when they "tapped in" with the EASY Card and point of destination when they "tapped out" upon exiting. The ridership and fare media data was used to calculate aggregate ridership for the month of March 2011, payment type, and fare media used. Further analysis delineated the percentage of cash, discount, and non-pass riders at Tri-Rail to MDT transfer stations which was further analyzed to include low income and minority ridership.

Although it was presumed that a price increase effectively impacts all transit riders, the daily ticket rider would incur the highest cost of travel and the regional EASY Card pass holder would pay the lowest travel cost. For example, the $\$ 140$ monthly pass would offer unlimited travel, including transfers to MDT; whereas a full-fare daily rider traveling five days per week for a total of 20 days per month, and paying an average round-trip fare of $\$ 5$ would incur a total travel cost of $\$ 160$ per month.

A March 2011 analysis revealed approximately 31 percent of customers paid with cash and approximately three fourths of all transit riders on the impacted routes were not benefitting from the regular monthly pass discounted rates.

Although the Fare Equity Analysis concluded that minority and low income transit riders would be minimally impacted by the transfer fee, MDT identified other customer alternatives to effectively offset the moderately higher cost of paying the single ride fare in comparison to the up-front cost of a monthly pass. The I-95 Express limited stop service, for example, allows travelers from Broward County who do not need to transfer a faster and cost effective ( $\$ 2.35$ per trip) alternative for travel along the I-95 corridor versus a transfer from Tri-Rail to Metrorail.

Another analysis of ridership data and projections indicated that fewer than 30 percent of all passengers originating at the four Tri-Rail stations receive some type of discount fare. Some are automatically eligible for a half-fare (i.e. Medicare recipient, persons with disabilities etc.), while others may be participants in an employer discount programs. With the proposed transfer fee, participants in MDTs employer discount program, for example, would be able to purchase the monthly regional pass at the discounted rate of $\$ 115$. Because this ridership segment provides the greatest opportunity for further growth, MDT proposed the initiation of a more aggressive campaign to promote the discount program to ensure maximum participation in the discounted rate programs. 
The final mitigation strategy proposed by MDT in the Fare Equity Analysis was a ridership survey designed to get more refined information about customer points of origin and destination and other ridership data to enhance its public outreach campaigns and assess any unanticipated disparate impacts of the regional EASY Card. 
This page intentionally left blank 


\section{Chapter 5}

\section{Other Florida Regional Fare Collection Initiatives}

\section{Other Florida Regional Fare Collection Initiatives}

In addition to the recently completed regional integration of the EASY Card system between MDT and SFRTA, several other initiatives related to fare integration are underway in the State of Florida as described below.

\section{Southeast Florida}

Broward County Transit (BCT) and Palm Tran in Palm Beach County continue to evaluate opportunities to develop a system that is interoperable with EASY Card. Both agencies are developing pilot projects to implement new fare collection technologies. The BCT portion of the pilot will include BCT express bus routes that serve Broward County, Miami-Dade County and Tri-Rail. The pilot project is planned for approximately $30 \mathrm{BCT}$ buses. BCT plans to acquire new onboard readers/validators capable of:

- Validating existing EASY Cards

- Validating mobile tickets

- Accepting fare payments using credit/debit cards, general purpose prepaid cards, third-party smart cards, and Near-Field-Communications enabled mobile phones.

Palm Tran plans to test the technology on approximately 10 vehicles. One of the routes where Palm Tran may deploy this technology is Route 94 which connects SFRTA with Florida Atlantic University.

BCT has budgeted approximately $\$ 3.8$ million to purchase the equipment necessary for fare interoperability, while Palm Tran has estimated their costs would be approximately $\$ 50,000 .^{3}$

The Florida Department of Transportation District 4 recently conducted a technology assessment that concluded regional fare interoperability in southeast Florida should be completed in a phased approach similar to what was done between MDT and Tri-Rail. The assessment emphasized that the technology is available, but implementation is difficult, particularly working through issues related to the coordination and consolidation of the finance and accounting functions. ${ }^{4}$

FDOT is also exploring opportunities to establishing a cost-effective means to achieve interoperability, share resources and capitalize on economies of scale. FDOT representatives have been in discussion with the Turnpike and FDOT Central Office to determine how they can capitalize on economies of scale by using the Sunpass electronic tolling system technology. Another scenario under consideration is the feasibility of implementing a single transit pass administered through a statewide system. ${ }^{5}$ 


\section{Central Florida Region}

SunRail is a new commuter rail line under development in Central Florida. The system is being built in two phases. Phase one, scheduled to open in 2014 will include 32 miles of track between Debary in Volusia County to Sand Lake Road in Orange County. In 2016 phase two is scheduled to open, which will extend service north to Deland from Debary in Volusia County and south to Poinciana in Osceola County from Sand Lake Road.

SunRail will offer daily tickets for infrequent riders and SunCard reusable smart card period passes good for unlimited rides (7 day, 30 day and annual) with an electronic purse. Fares are based on the number of zones/counties traveled. Tickets and SunCards will be available for purchase and reloading at any of the four TVMs located at each station, online, and through participating retailers.

Similar to MDT's Metrorail system, SunRail will use a "tap on-tap off" system for deducting fares. Each station will have six validator units where customers can tap their card or ticket on the screen and wait for the beep before boarding the train. When arriving at their destination customers tap the card or ticket again before exiting the station.

LYNX, which is operated by the Central Florida Regional Transportation Authority, provides bus service in Orange, Seminole and Osceola Counties. Votran provides bus service in Volusia County. Both LYNX and Votran will provide bus feeder service to SunRail stations located in their respective service areas.

SunRail, LYNX and Votran have worked together to develop and procure a smart card based system that will allow for seamless travel on any one or combination of these agencies' services.

LYNX and Votran riders on a feeder bus route to any SunRail station will be able to transfer free of charge within one county by swiping their bus fare media card at any SunRail TVM. Transferring passengers that need to travel multi-county will pay a $\$ 1.00$ upgrade for crossing each county line on SunRail.

\section{Tampa Bay Region}

In November of 2012, the Hillsborough Area Regional Transit Authority (HART) convened a working group consisting of transit agencies and transit providers from FDOT District 7 (Hillsborough, Pinellas, Pasco, Citrus, and Hernando) as well as FDOT District 1 agencies (Polk and Manatee) to begin working together to develop a regional approach to revenue collection that will not only modernize the process of the collection of fixed-route fares, but also enhance the mobility of passengers between the agencies' respective jurisdictions.

The members of the Regional Working Group currently maintain and utilize a variety of technology infrastructure and supporting business processes to collect fares on their fixed route systems. Currently, the fixed-route systems operated by Regional Working Group representatives only accept cash, coin, or individual system fare media (typically magnetic stripe passes exclusive to the providing agency), with no current ability to accept other forms of payment (e.g., smart cards), or any other system's fare media. If a passenger 
wants to move between jurisdictions they must purchase fare media from multiple systems to complete their journey.

The Regional Working Group has proposed the development of a regional fare collection system that will allow interoperability among the respective systems for infrastructure and management support, while providing a common fare media to allow for seamless travel throughout the Tampa Bay region. Using a systematic and phased approach, the Regional Working Group will consider equipment and technology needs along with the development of common fare policies and processes and work toward the evaluation, procurement and implementation of a single fare media for all members.

The Regional Working Group implementation strategy involves a four-phased approach, with each phase being defined by Fiscal Year: Phase I in FY2014, Phase II in FY2015 and Phase III in FY2016 with a 2017+ "Future Phase." In response to initial available funding, Phase I is divided into Phase IA and Phase IB. Due to Regional Working Group member priorities, Hillsborough, Pinellas and Polk will be the agencies involved in the pilot phase, with other Regional Working Group members participating in the subsequent phases. Phase I will allow for an opportunity to evaluate current processes that support revenue collection and the mobility of passengers utilizing this new functionality prior to full implementation and expansion of a regional fare system. Key deliverables during this phase will be individual member installation and testing on selected routes and vehicles, Regional Working Group collaboration and development of a common regional fare schedule and policy, and evaluation of inter-jurisdictional travel using the new smart card system.

During Phase 1, Pinellas Suncoast Transit Authority will add smart card technology to a portion of its fleet operating on inter-jurisdictional routes to Pasco and Hillsborough. Farebox covers will be out-fitted to accept smart card technology or separate units may be connected to the existing farebox which will accept smart card technology without the capital outlay for new fareboxes. POS terminals and TVMs will be installed at terminals and select locations.

HART will make smart card technology available on vehicles operating on the MetroRapid North-South BRT corridor, as well as vehicles that serve on the inter-jurisdictional routes crossing Tampa Bay to Pinellas County. The MetroRapid corridor will have TVMs installed which will be smart card functional.

Also during Phase 1, Polk Transit (Lakeland Area Mass Transit District, Winter Haven Area Transit and Polk Transit) will replace the existing fare collection equipment that is in most cases in excess of 20 years old, allowing Polk Transit to test the new fare collection equipment and adapt to new processes prior to further phased implementation.

Following successful completion of Phase 1, future phases will involve additional equipment purchases and other fare related support services for Phase 1 partners and expansion of the regional fare collection initiative to include Hernando, Citrus and Manatee Counties.

The Working Group recently submitted a funding request to the Florida Department of Transportation. It is anticipated that FDOT will provide annual funding support for this regionally significant project. ${ }^{6}$ 
This page intentionally left blank 


\section{Chapter 6}

\section{Synthesis of Study}

The scope for this project contained several objectives to be addressed and questions to be answered in the course of the study. In this section, a synthesis is provided to address the objectives and questions to the extent possible, based on available data.

\section{Fare Policy Changes and Incentives Associated with the EASY Card System}

The most notable changes associated with the introduction of EASY Card were related to the elimination of paper and magnetic transfers issued by bus drivers which were replaced by transfers encoded on the EASY Card. The fare structure itself is a strategy designed to incentivize the use of EASY Cards and EASY Tickets. In December 2009, MDT eliminated Metrobus to Metrobus transfers. Interestingly, this action was related to a service change that was going to effectively reduce service and cause more transfers. Since the AFCS had just been introduced, the elimination of transfers became logical. If customers transfer using an EASY Card or EASY Ticket, tranfers are free. However, customers paying cash must pay the $\$ 2.00$ full fare (or reduced fare) each time they board a bus. Therefore, EASY Cards and EASY Tickets offer a significant savings for all customers who require a transfer to complete their trip. EASY Card and EASY Ticket holders also pay a reduced fare transfer fee for transfers between bus and rail modes.

The primary strategy in providing incentives for Metrorail customers to convert to EASY Card and EASY Ticket use is that all other forms of fare payment were eliminated on Metrorail. Tokens were honored (but not sold) for a period of time after implementation, but by 2012 all Metrorail customers used EASY Cards and EASY Tickets.

An additional incentive for the use of EASY Cards and EASY Tickets is related to the relative ease of purchase. Since there are TVMs at every Metrorail station, customers can easily make spur of the moment purchasing decisions at their own convenience. Tourists, visitors and other first time users can also easily purchase fare media to use Metrorail on a temporary basis. For Metrobus customers not traveling to Metrorail stations, there are 86 retail outlets, the Ticket Office at the Government Center, and three 3-1-1 County service centers where fare media can be purchased. All customers may purchase fare media via the internet.

Transfer policies between Tri-Rail and MDT were adopted on October 1, 2011. Anyone holding a regional monthly pass can ride seamlessly on Tri-Rail, Metrorail, and Metrobus. Without a regional monthly pass, customers must possess enough cash value on an EASY Card or EASY Ticket in order to pay transfer fees. Tri-Rail customers using a paper ticket (the only remaining paper fare instrument in the Tri-Rail system) must pay full fare when transferring to Metrobus and Metrorail. These customers can board a Metrobus with cash; however, only EASY Cards and EASY Tickets are accepted on Metrorail. The transfer policy clearly states that regular MDT-issued passes cannot be used on Tri-Rail and regular Tri- 
Rail-issued passes cannot be used on any MDT service with the exception of the monthly regional pass.

\section{Ridership Impacts, Trip Characteristics and Trip Patterns}

Following a detailed analysis of available data, the research team concluded that several of the study's original objectives could not be fully addressed. First and foremost, this study cannot draw conclusions regarding ridership impacts that can be directly attributed to the implementation of the AFCS. There have been significant fluctuations in MDT's overall ridership over that last several years. For example, in FY 2008, Metrobus ridership peaked at 84.8 million, then declined to 75.6 million in 2009, 70.5 million in 2010, then increased to 75.7 million in 2011 and 77.8 million in 2012. Correspondingly, Metrorail ridership peaked at 18.5 million in FY 08, then declined to 18.2 million in 2009, then to 17.4 million in 2010 before increasing to 18.1 million in 2011 and 18.7 million in 2012. The ridership declines through 2010 likely correspond to the downturn in the economy and the increases after 2010 could equally correspond to improvements in the economy. Other factors such as demographic shifts, the price of fuel, and service changes are examples of external factors that can impact fluctuations in ridership that cannot be attributed to the availability, or lack of availability, of EASY Cards/EASY Tickets.

Additionally, this research cannot address trip characteristics and trip patterns for two reasons. First, customers have a choice of purchasing an EASY Card/EASY Ticket anonomously, which simply means their card will not be replaced if lost or stolen. Customers who choose to register their EASY Card/EASY Ticket have the protection of replacement if lost or stolen. Second, the Florida legislature enacted Florida Statute 341.3026, stating that, "Personal identifying information held by a public transit provider, as defined in s. 341.031 , for the purpose of facilitating the prepayment of transit fares or the acquisition of a prepaid transit fare card or similar device is exempt from s. 119.07 (1) and s. 24(a), Art. I of the State Constitution. This means that individual travel destinations are not a matter of public record. Therefore, there is no way to determine the magnitude by which the implementation of AFCS opened up travel opportunities for customers to experience what they otherwise would not have experienced pre-implementation.

\section{Growth Rate of EASY Card/EASY Ticket in Post-Implementation}

Utilization of EASY Cards and EASY Tickets on Metrorail did not follow a consistent trend over the three year period. In 2010, EASY Card ridership was 10.7 million while EASY Ticket ridership was 5.5 million. In 2011, EASY Card ridership was 13.0 million while EASY Ticket ridership declined to 4.7 million. Then, in 2012, EASY Card ridership dipped back down to 10.2 milion while EASY Ticket ridership increased to 6.7 million. Therefore, the real growth rate as of 2012 is EASY Ticket ridership at a 43 percent increase over 2011 (see Figure 6$1)$. 


\section{RIDERSHIP IMPACTS OF SOUTH FLORIDA'S EASY SMART CARD}

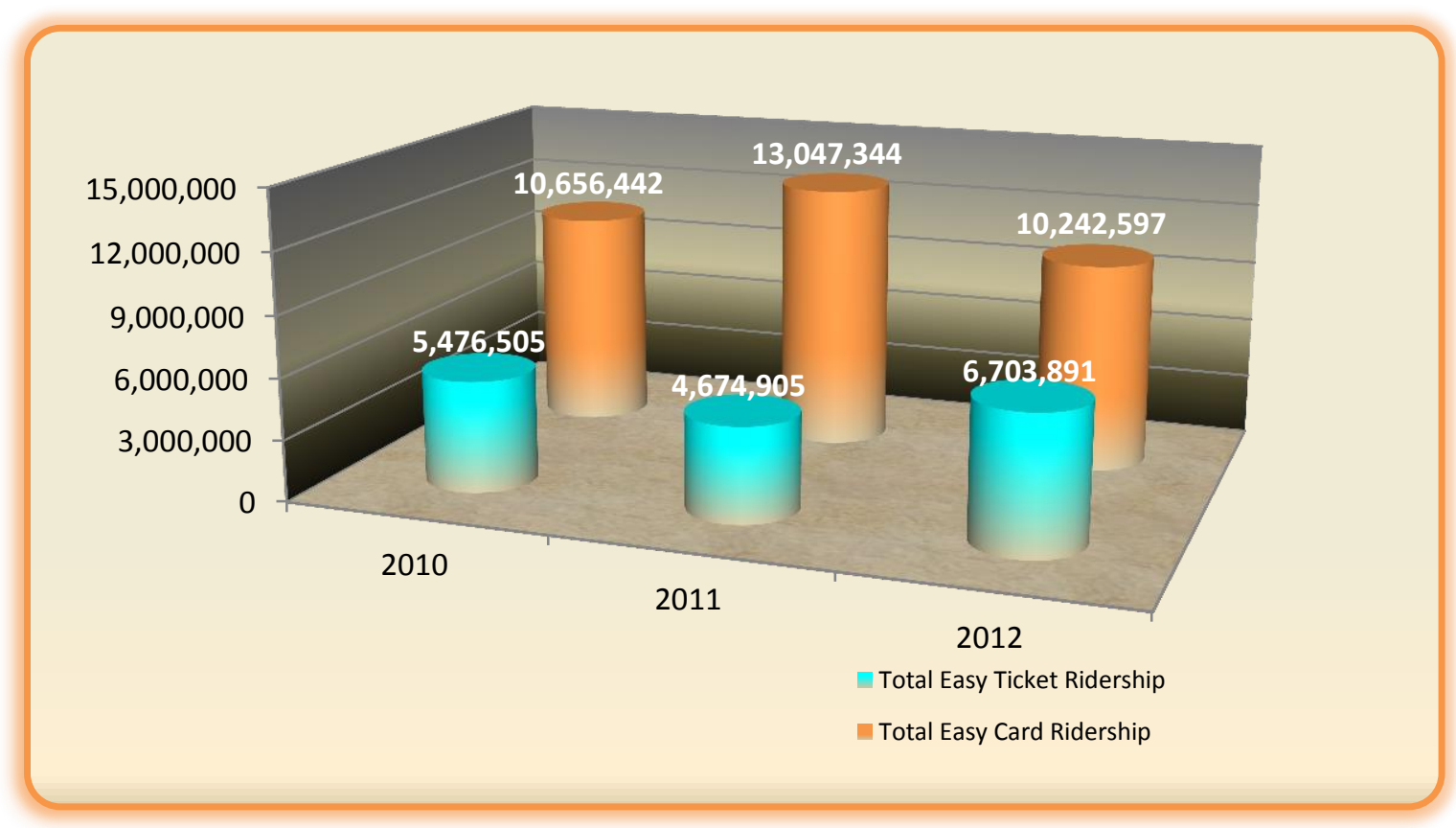

Figure 6-1. Metrorail Ridership by Fare Type, FY 2010-2012

As shown in Figure 6-2, there was modest growth in Metrobus ridership for EASY Card and EASY Ticket between 2011 and 2012. In 2011, EASY Card ridership was 41.2 million and increased 2.8 percent to 42.3 million in 2012. EASY Ticket ridership in 2011 was 11.0 million and increased 4.9 percent to 11.5 million in 2012.

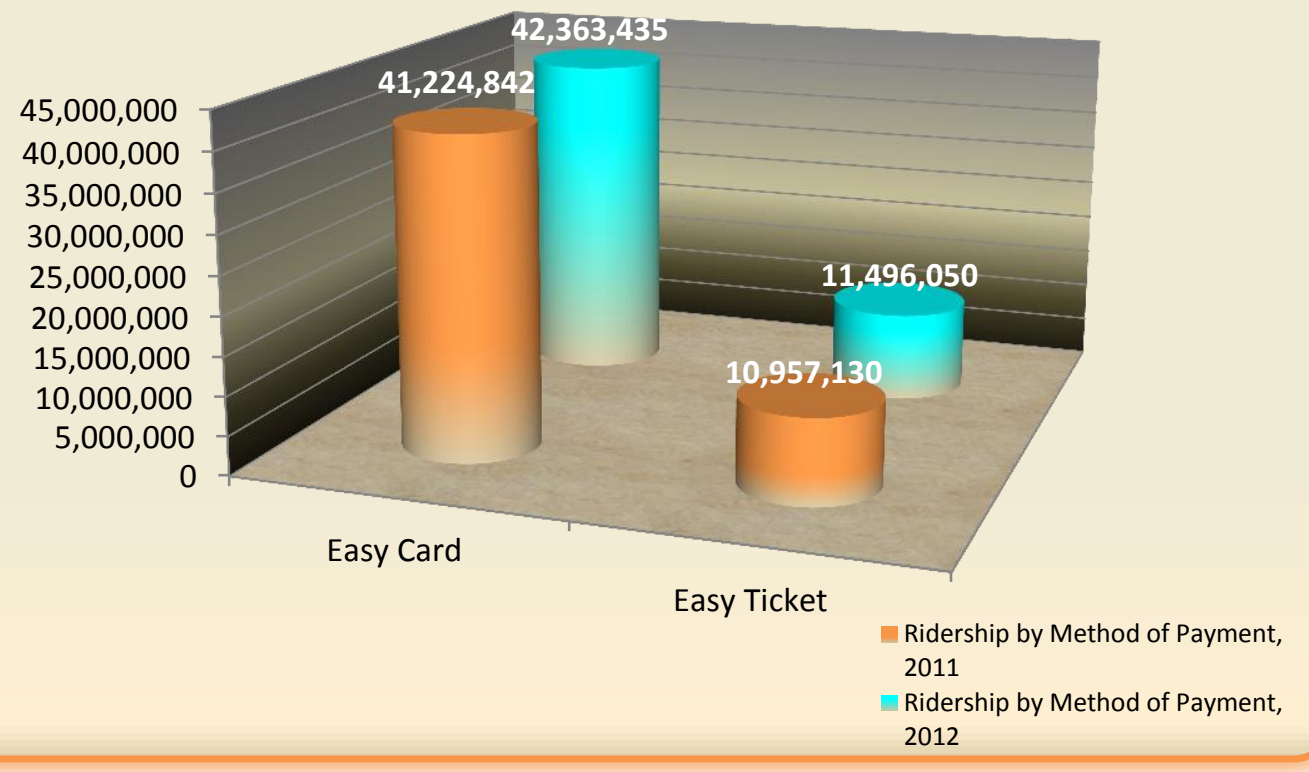

Figure 6-2. Metrobus Ridership by Method of Payment, FY 2011-2012 
Figure 6-3 below displays total EASY Card and EASY Ticket ridership in relation to total ridership for both modes. In 2011, total EASY Card/EASY Ticket ridership was 69.9 million, or 74.9 percent of the total ridership of 93.3 million. In 2012, total EASY Card/EASY Ticket ridership increased to 70.8 million but was 73.3 percent of the total ridership of 96.5 million for the two modes. While there were no significant changes, the fact is that within three years of implementation, three of every four trips taken on these two modes are paid with EASY Card or EASY Ticket.

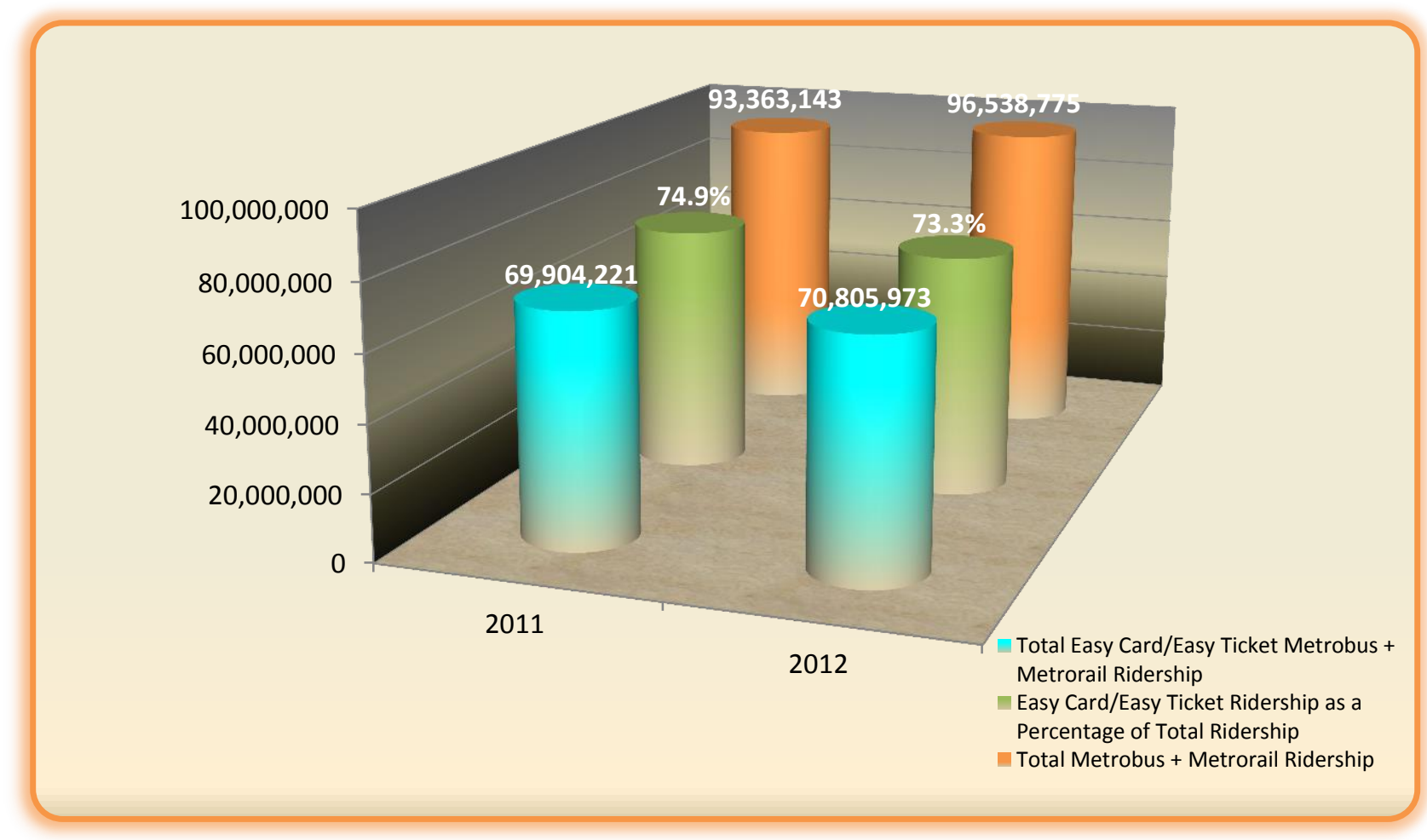

Figure 6-3. Combined Easy Card/Easy Ticket Ridership Compared to Total Metrobus + Metrorail Ridership, FY 2011-2012

\section{Programmatic Impacts on Ridership}

This study presented sales by transaction, major fare media and ridership by fare category when possible. The fare media legend provided by MDT appears to have evolved over time and contains 145 unique fare categories. For instance, as marketed, the College and University Discount Program (CUDP) is a Monthly Metropass on an EASY Ticket. In the fare legend there is a category listed as College Monthly Pass, College Monthly Parking and Stored Value College; however, none of these fare categories are reported in ridership data for Metrobus or Metrorail. There is another fare category listed as "Monthly Ticket." By definition, this would be a Monthly Metropass on an EASY Ticket; however, it is impossible to know whether all trips are CUDP or whether the same fare media is available to the general public at the full price of $\$ 100.00$. The seamless nature of EASY Card/EASY Ticket creates greater convenience for customers but does not contribute to the greatest level of 
reconciliation in research. Sales in 2012 were 10 percent greater than 2010 and tracking at greater than $\$ 400,000$ annually.

For the Corporate Discount Programs (CDP), in the first year the fare category was a 7-Day Corporate Pass. This was converted in 2011 to a fare category of Prepaid Benefit Monthly (PPM), which is the monthly pass loaded on EASY Card for the CDP. Figure 6-4 below shows there were significant gains in EASY Card Metrorail ridership for the period 2010-2012. This comparison shows that in 2010, ridership was at 1.7 million, declining to 1.6 million in 2011 and then increasing 35.2 percent to 2.1 million in 2012 .

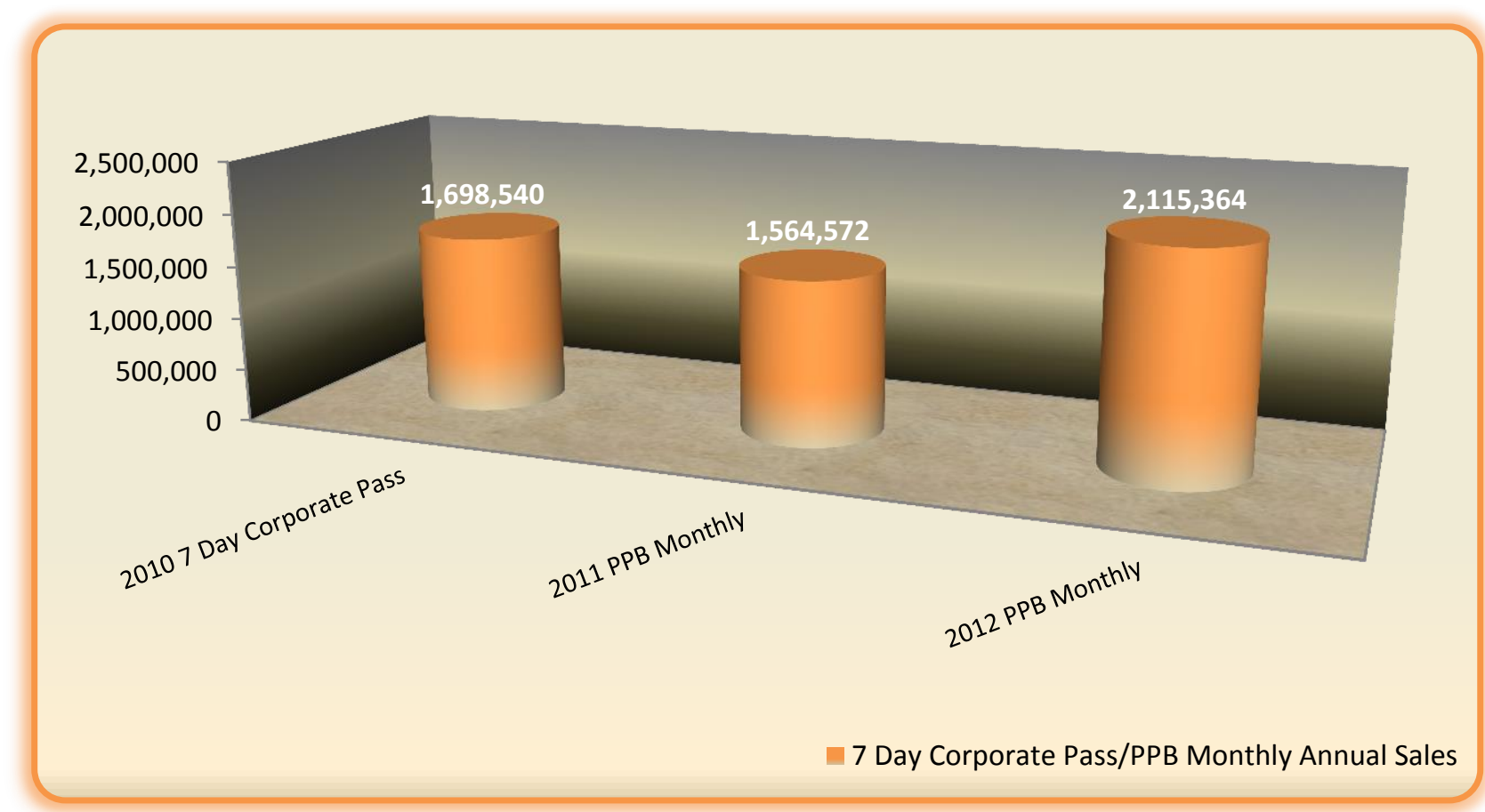

Figure 6-4. Metrorail - 7 Day Corporate Pass/PPB Monthly Pass Annual Ridership FY $2010-2012$ 
Figure 6-5 display Metrobus ridership for the CDP in 2011 and 2012. This graphic shows that EASY Card ridership went from 1.3 million in 2011 and increased 18.6 percent in 2012.

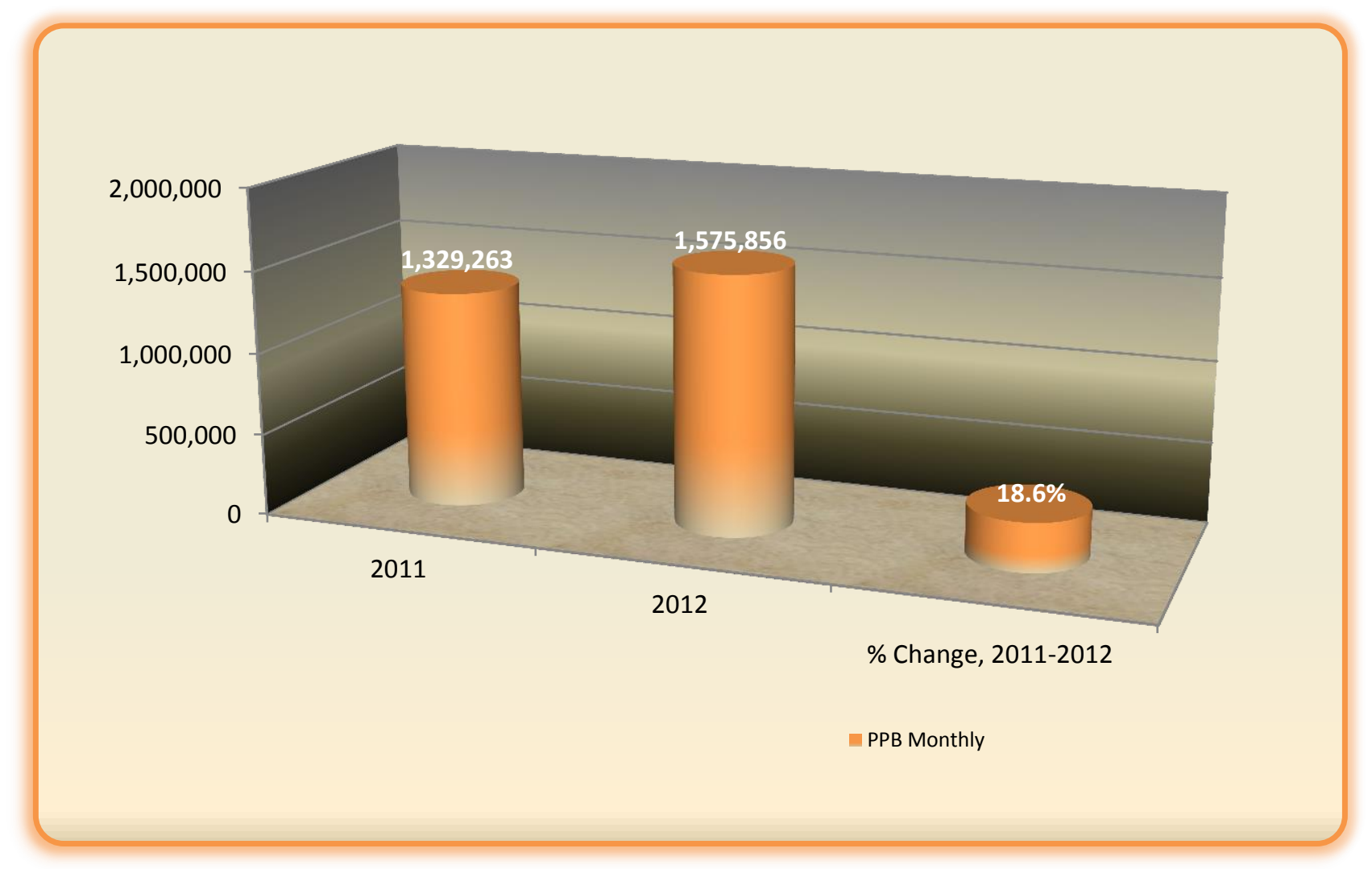

Figure 6-5. Metrobus Ridership - Corporate Discount Program, Annual Ridership, FY 2011-2012

It is likely that the free fare programs had a huge impact on customer motivation to switch to EASY Card because the Golden Passport, Patriot and annual Social Security Benefit programs require the acquisition of an EASY Card in order to utilize the system.

For Golden Passport customers, the key provided by MDT includes only one fare category, GOLDPASS, and it is actually a cash fare category. For EASY Card and EASY Ticket, there are the categories of annual Social Security Benefit and Stored Value Elderly. Figure 6-6 displays ridership for Metrorail for the three year period for these two fare categories. This graphic shows that while Stored Value Elderly ridership was declining between 2010 and 2012, Annual Social Security Benefit ridership was on the rise. When shown together, there were an average of 2.2 million passenger trips over the three year period. 


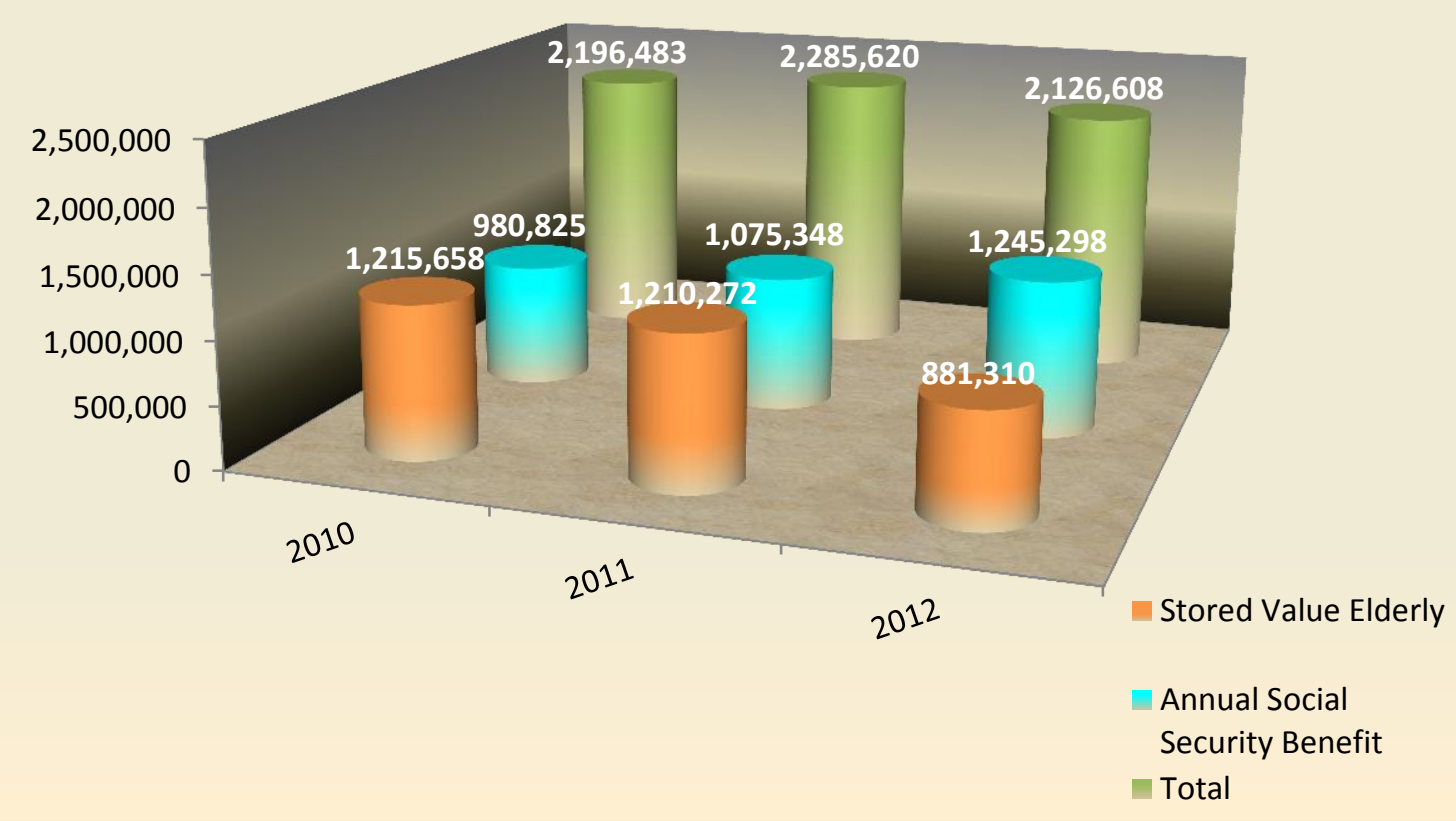

Figure 6-6. Metrorail - Stored Value Elderly/Annual SSB Annual Ridership, FY 2010 - 2012

For Metrobus, the ridership figures for Stored Value Elderly and Annual Social Security appear to be too inconsistent to report. In 2011, SV Elderly was 12 million passenger trips and dropped to below 5 million, in 2012. However, Annual SSB was 6 million in 2011 and only rose to 7 million in 2012. Thus, it appears that when combined, ridership declined by more than 5.8 million passenger trips. 
Figure 6-7 shows the change in Annual Patriot Pass ridership on Metrorail for the three year period. While not the strongest in ridership by fare category, ridership did increase from 332,415 in 2010 to 358,751 (7.9 percent) in 2011 and 374,462 in 2012 (4.4 percent).

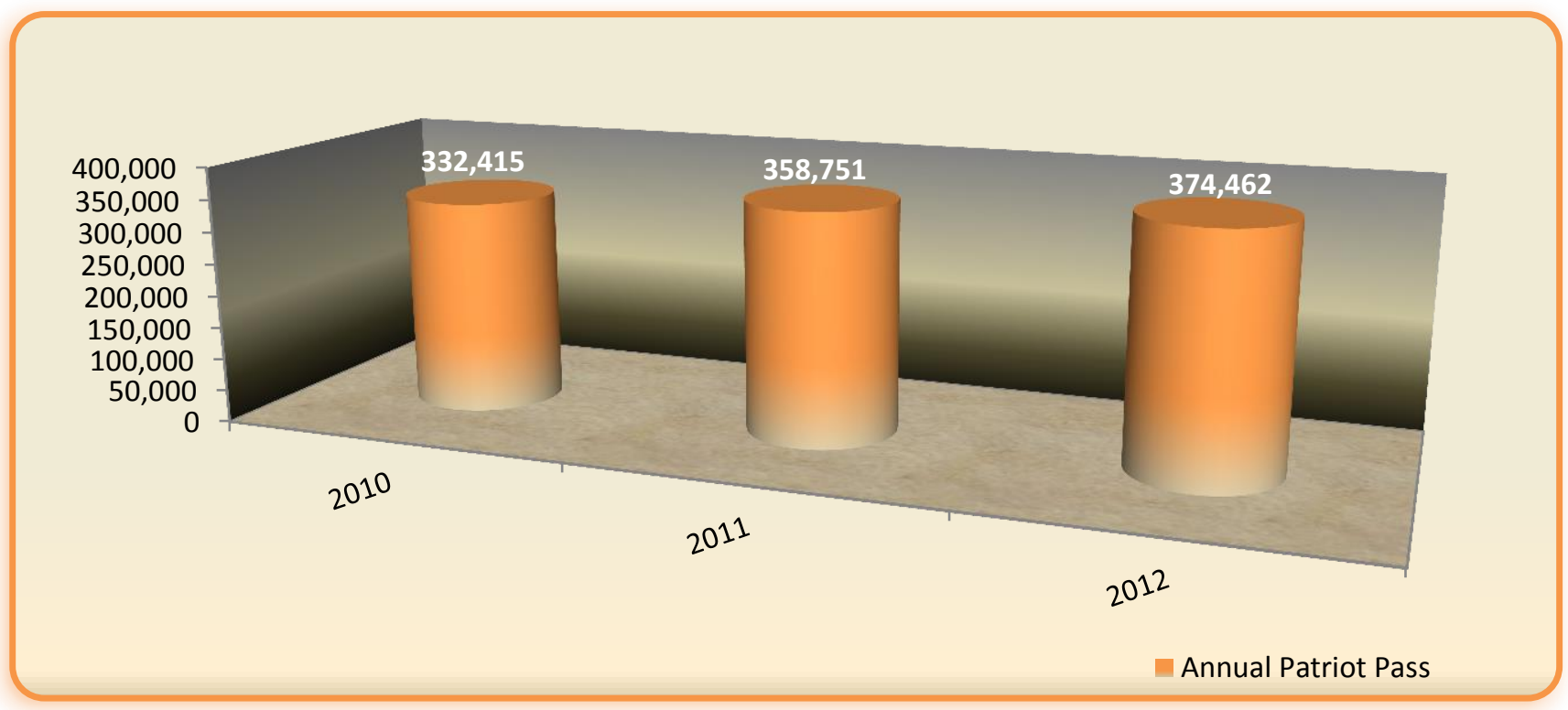

Figure 6-7. Metrorail - Annual Patriot Pass Ridership, FY 2010- 2012

Figure 6-8 below displays ridership for the Annual Patriot Pass on Metrobus. Ridership was 1.2 million in 2011 but declined slightly in 2012 to 1.19 million.

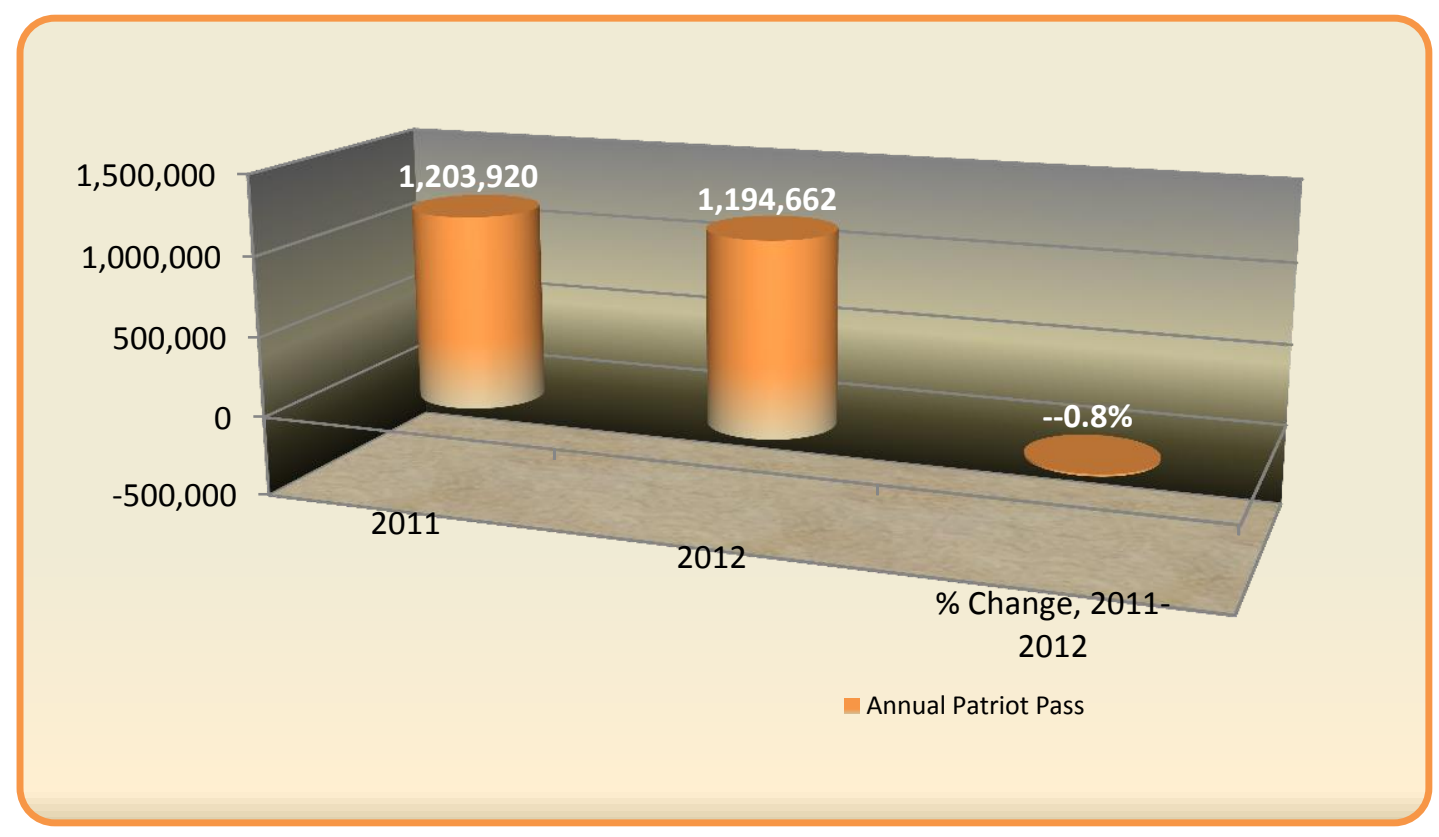

Figure 6-8. Metrobus Ridership - Annual Patriot Pass, Annual Ridership 


\section{Customer Satisfaction}

In addition to the analysis of the raw data related to EASY Card and EASY Ticket sales and utilization, additional insight into customer acceptance considerations was gained through a series of interviews conducted with key MDT and SFRTA staff involved in the AFCS's planning and deployment. There was consensus that the pre-deployment education and awareness campaign utilizing a variety of media and outreach activities coupled with extensive hands-on interaction with customers at stations and terminals was of significant benefit to the successful roll-out. Successful techniques used to enhance adoption and satisfaction included the distribution of free introductory EASY Cards, and for a short period of time following roll-out, some flexibility in terms of fare payment or fare forgiveness for customers who encountered difficulties understanding the new system. Still, there was some resistance to adopting the new fare technology and fare structure changes, with staff reporting that the most problematic was the new requirement that customers "tap-out" to ensure the appropriate fares were charged. This and other aspects of customer satisfaction were not substantiated by post-implementation customer surveys and a lack of data on measures of customer convenience based on stated pre-deployment benefits.

The agencies found little resistance from customers regarding a greater reliance on the use of credit cards to maximize the convenience offered by the EASY Card system. However, TVM data shows that cash payment for stored value products at $\$ 64.8$ million (77 percent) still far exceeds credit or debit card transactions at $\$ 19.1$ million (23 percent).

Some customers expressed concerns about the system's ability to track their personal information about travel patterns. In response, the agencies include an explanation in informational and outreach materials about Florida laws that protect an individual's smart card transaction and travel information from public record requests.

Staff also reported the additional feature allowing for a balance transfer in the event a registered smart card is lost or stolen also enhanced customer acceptance. There currently is no survey data measuring customer satisfaction and there is no data on comparison measures for customer convenience based on stated pre-deployment benefits.

\section{Changes in Customer Behavior}

Clearly there is one change in customer behavior that can be attributed to the AFCS implementation which is the variety of sales outlets and the ability to reload fare media not available prior to the AFCS. TVMs are the most popular sales outlet with $\$ 84.8$ million or 62.6 percent of all sales over the three year period. Retail sales outlets are also popular accounting for $\$ 31.6$ million in all sales, or 23.3 percent of all sales for the period. TOMs account for $\$ 13.2$ million, just under 10 percent of all sales for the period.

True changes in behavior are difficult to track because a sales transaction is a pre-travel accounting and ridership is a post travel accounting. Also, the fare media are intended to be seamless between the two modes. For example, which customers accessed the internet to purchase fare media? It is impossible to answer whether customers of Metrobus, Metrorail, or both modes made the purchase. Also, it is impossible on the back end to track the ridership by fare category as to where or how the media were purchased. 


\section{Customer Markets Switching to EASY Card/EASY Ticket}

As noted before, Metrorail eliminated all other forms of payment and all customers have switched to EASY Card/EASY Ticket. However, the fact that MDT has been able to achieve 70-percent of all passenger trips with fares paid by EASY Card/EASY Ticket is an extraordinary accomplishment. Miami-Dade County is one of the most multi-cultural and multi-lingual communities in the world. The success of the AFCS with Metrobus customers speaks to the agency's commitment to branding, marketing, communications, community outreach, targeted outreach, and availability of information in multiple language formats.

\section{Equity and/or Civil Rights Issues}

To ensure equity in terms of EASY Card access, particularly for low income and minority populations, MDT focused on establishing an extensive network of EASY Card sales outlets for customers who don't want to purchase online or can't conveniently travel to other outlets such as Metrorail stations or the Government Center. For example, the Sedano Supermarket chain, popular within the Hispanic community, sells EASY Cards at approximately 26 of its locations. MDT also established a retail account with 32 Advance America Cash Advance outlets that offer pay day loans, primarily to lower income residents in Miami-Dade County.

Another mitigation strategy proposed by MDT in a Fare Equity Analysis was a ridership survey designed to get more refined information about customer points of origin and destination and other ridership data to enhance its public outreach campaigns and assess any unanticipated disparate impacts of the regional Easy Card.

\section{Card Theft and Fraud}

Reports of fraudulent activity associated with EASY Card have been minimal, but additional internal controls were implemented following system rollout. Initially, the AFCS did not have the ability to validate the zip codes associated with credit card purchases, but that feature is now available. In the event of a communication failure that prohibits MDT from validating zip code data MDT instituted a policy that caps credit card charges at $\$ 112$ (or three transactions) per day.

Overall, the EASY Card system was estimated to have reduced fare evasion by approximately 10 percent as a result of fareboxes that detect counterfeit or non-local currency.

\section{Data Collection}

As previously described, MDT anticipated the AFCS would offer significant improvements in both the breadth and accuracy of data to facilitate planning and additional opportunities to prevent fraud. MDT procured a system for generating reports that authorized personnel could access via MDTs intranet. Users can request preformatted reports either immediately, on a scheduled basis, or through ad-hoc data queries originating from the data base.

MDT's contract for the central computer system identified over 250 preformatted reports that would be available from the new AFCS. The reports included information ranging from 
fare transactions for specific devices, fare media stock locations, debit/credit details, fare auto-load information, entry/exit by day and hour, ridership totals by time of day, web sales summary, cash transactions, and hot listed card activity. Transaction-level reports for user defined start and end points including route/run/trip ID, date/time/value of transaction, validity of fare, and linked or unlinked trip information are also provided by the system. MDT staff reported that the volume of available data can be overwhelming, yet even with the significant amount of readily available data, based on staff requests there is still a desire for additional data beyond those available in the preformatted reports. Although customized reports can be generated, there can be significant costs associated with their creation.

\section{Implementation Recommendations}

Although not necessarily a direct or immediate impact on customer acceptance and adoption, staff made the following recommendations and observations for others considering deployment of a smart card system:

- Don't rush - create a reasonable implementation schedule.

- Carefully evaluate fare policy and structure and incorporate desired changes before introducing the AFCS.

- Create a thorough and well-designed card distribution plan, with special attention to the needs of corporate customers.

- Engage agency representatives from all functional areas in planning and deployment. Develop a thorough documentation of business practices for each department to make transition activities smoother and operating in post-implementation more efficient.

- Anticipate the need for additional financial and accounting staff and create a business processing system closely aligned with the Information Technology function.

- Pre-define reporting requirements and data needs by functional area.

- Anticipate significant benefits in terms of enhanced system functionality, control, ridership and revenue reporting, and data reliability. 


\section{BIBLIOGRAPHY}

Transportation Research Board. Smartcard Interoperability Issues for the Transit Industry. TCRP Report, Issue 115, 2006, p. 107.

Iseki, Hiroyuki, Alexander Demisch, Brian D. Taylor, Allison C. Yoh. Evaluating the Costs and Benefits of Transit Smart Cards. California Path Program Institute of Transportation Studies, University of California, Berkeley. August 2008.

Transportation Research Board. Multipurpose Transit Payment Media. TCRP Report 32. 1998.

Iseki, Hiroyuki, Brian D. Taylor, Allison Yoh. Smart Cards, Slow Deployment: Findings from Interviews with U.S. Transit Agencies. January 2008.

Federal Transit Administration. Electronic Fare Collection Options for Commuter Railroads. September 2009.

Virginia Department of Transportation. Regional Payment Systems Partnership Action Plan. September 25, 2000.

McDonald, Noreen. Multipurpose Smart Cards in Transportation: Benefits and Barriers to Use. December 9, 2000.

Yoh, Allison C., Hiroyuki Iseki, Brian D. Taylor, David A King. Institutional Issues and Arrangements in Interoperable Transit Smart Card Systems: A Review of the Literature on California, United States and International Systems. March 2006.

\section{REFERENCE}

${ }^{1}$ Miami-Dade Transit Automated Fare Collection System Technical Service Business Plan, February 2009.

${ }^{2}$ FY 2013 - FY 2022 MDT Transit Development Plan Annual Update.

${ }^{3}$ Southeast Florida Transportation Council, July 23, 2012 Meeting Minutes.

${ }^{4}$ Southeast Florida Transportation Council, October 22, 2012 Meeting Minutes.

${ }^{5}$ Southeast Florida Transportation Council, July 23, 2012 Meeting Minutes.

${ }^{6}$ Regional Revenue Collection and Inter-Jurisdictional Mobility Proof of Concept Project State Funding Request FY 2014-FY 2017, April 30, 2013. 